\title{
Influência do envelhecimento das células-tronco mesenquimais na autorrenovação, diferenciação e multipotência de células-tronco hematopoéticas
}

\author{
Dissertação apresentada à Faculdade \\ de Medicina da Universidade de São \\ Paulo para obtenção do título de \\ Mestre em Ciências \\ Programa de Alergia e \\ Imunopatologia \\ Orientadora: Dra. Luciana Cavalheiro \\ Marti
}

São Paulo 


\section{Influência do envelhecimento das células-tronco mesenquimais na autorrenovação, diferenciação e multipotência de células-tronco hematopoéticas}

Dissertação apresentada à Faculdade de Medicina da Universidade de São Paulo para obtenção do título de Mestre em Ciências

Programa de Alergia e Imunopatologia

Orientadora: Dra. Luciana Cavalheiro Marti

São Paulo 
Dados Internacionais de Catalogação na Publicação (CIP)

Preparada pela Biblioteca da

Faculdade de Medicina da Universidade de São Paulo

Creprodução autorizada pelo

Benedito, Suzana da Silva

Influência do envelhecimento das células-tronco mesenquimais na autorrenovação, diferenciação e multipotência de células-tronco hematopoéticas / Suzana da Silva Benedito. -- São Paulo, 2016.

Dissertação(mestrado)--Faculdade de Medicina da Universidade de São Paulo. Programa de Alergia e Imunopatologia.

Orientadora: Luciana Cavalheiro Marti.

Descritores: 1.Nicho de células-tronco 2.Células-tronco hematopoéticas 3.Célulastronco 4.Medula óssea 5.Células mesenquimais estromais 6.Envelhecimento 


\section{DEDICATÓRIA}

Aos meus queridos pais, Dorotéa e João Alberto, e ao meu marido Rodrigo Calixto por todo apoio,carinho, amor, paciência e dedicação. 


\section{AGRADECIMENTOS}

Agradeço à Deus, por estar presente e ao meu lado em todos os momentos da minha vida.

Aos meus queridos pais, João Alberto e Dorotéa Cristina por terem me ensinado os princípios básicos da vida, por sempre me guiarem no caminho da Fé e do Amor e por estarem presentes em todos os momentos sejam eles bons ou ruins.

Ao meu marido, Rodrigo Calixto por todo o apoio, carinho e paciência. Por sempre acreditar em mim, pelas palavras edificadoras, pelos conselhos, abraços nas horas difíceis e por não medir esforços para que eu pudesse concluir esta importante etapa da minha vida.

Às minhas irmãs Daniele e Caroline por toda alegria e companheirismo.

À minha orientadora Dra. Luciana Cavalheiro Marti, por ter me escolhido para ser sua aluna, por ter acreditado em mim, ser paciente e compreensiva em todos os momentos da realização deste estudo, por todos os conhecimentos e conceitos que foram essenciais para que eu tivesse um novo olhar para a Ciência e pela grande contribuição em meu crescimento pessoal e profissional.

Às minhas colegas de grupo, Msc Marília Normanton, Msc Heliene Alvarenga, Laiz Bento, Bianca de Leon e Diana Palomino por toda ajuda, por ter dividido seus conhecimentos e compartilhado momentos de alegria. Em especial, gostaria de agradecer imensamente à amiga Dra. Camila Almeida pela paciência e atenção, por ter me ajudado muito nos momentos em que eu mais precisei. Você para mim, é um exemplo de pessoa e profissional.

Obrigada à toda minha família e amigos que de uma maneira geral contribuíram de alguma forma para a realização e conclusão deste trabalho.

Aos gestores do Instituto de Ensino e Pesquisa Albert Einstein, Luiz Vicente Rizzo e Ana Carla Goldberg pela oportunidade, por fazer um trabalho sério e de qualidade, pelo carinho, conselhos, "puxões de orelhas" nos seus pós-graduandos, e acreditar que é possível fazer pesquisa de qualidade e formar excelentes pesquisadores. 
Aos funcionários e alunos de pós-graduação do laboratório, em especial à Marta Diniz, pela amizade, alegria, risadas, carinho, cuidado e zelo com os meus materiais e laboratório. Obrigada pelo apelido carinhoso que sempre irei carregar comigo!

À Fundação CAPES e ao Instituto UNIEMP, pelo apoio financeiro para a realização do projeto, pelo interesse no assunto e pela bolsa auxílio.

Ao Instituto de Ensino e Pesquisa Albert Einstein pelo espaço físico e equipamentos de qualidade.

À Faculdade de Medicina da USP, em especial ao departamento de Alergia e Imunopatologia, pelo espaço físico, pelos excelentes professores, disciplinas e por estar tornando um sonho em realidade.

Obrigada! 


\section{EPÍGRAFE}

\section{Mais Uma Vez}

"Mas é claro que o sol vai voltar amanhã

Mais uma vez, eu sei

Escuridão já vi pior, de endoidecer gente sã

Espera que o sol já vem

Tem gente que está do mesmo lado que você

Mas deveria estar do lado de lá

Tem gente que machuca os outros

Tem gente que não sabe amar

Tem gente enganando a gente

Veja a nossa vida como está

Mas eu sei que um dia a gente aprende

Se você quiser alguém em quem confiar

Confie em si mesmo

Quem acredita sempre alcança

Nunca deixe que lhe digam que não vale a pena

Acreditar no sonho que se tem

Ou que seus planos nunca vão dar certo

Ou que você nunca vai ser alguém

Tem gente que machuca os outros

Tem gente que não sabe amar

Mas eu sei que um dia a gente aprende

Se você quiser alguém em quem confiar

Confie em si mesmo

Quem acredita sempre alcança...

Quem acredita sempre alcança...

Quem acredita sempre alcança...

Quem acredita sempre alcança...”

\section{Legião Urbana}




\section{LISTA DE FIGURAS}

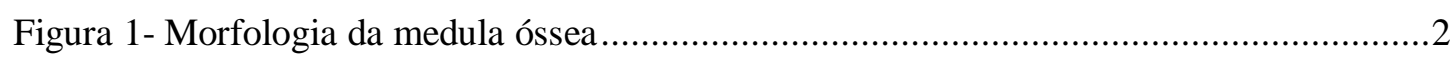

Figura 2- Desenho esquemático da hematopoese ….........................................................

Figura 3- Células-tronco hematopoéticas e células progenitoras restritas ocupam distintos

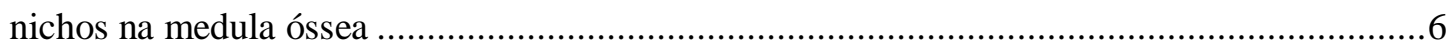

Figura 4- Componentes celulares do nicho de células-tronco hematopoéticas .........................16

Figura 5- Separador de células mimiMacs, utilizado na separação de células CD34+ ............29

Figura 6- Perfil de expressão fenotípica de células-tronco hematopoéticas isoladas da medula

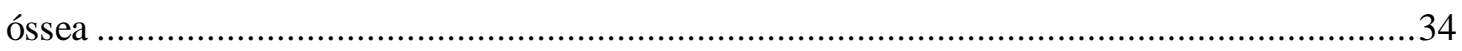

Figura 7- Diferenciação das células-tronco mesenquimais em adipócitos, condrócitos e

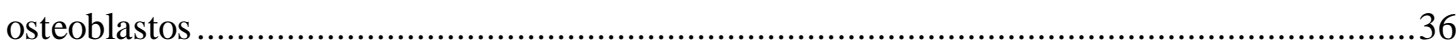

Figura 8- Perfil de expressão fenotípica de células-tronco hematopoéticas isoladas do sangue

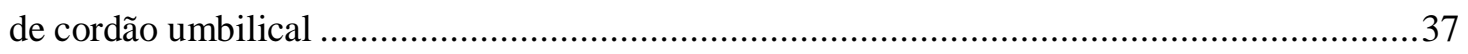

Figura 9- Análise citoquímica de células-tronco hematopoéticas e mesenquimais ..................38

Figura 10- Percentagem de células $\mathrm{LinCD}^{-} \mathrm{CH}^{+}$co-cultivadas com células-tronco mesenquimais

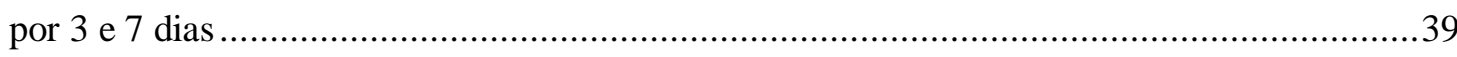

Figura 11- Percentagem de células $\mathrm{Lin}^{-} \mathrm{CD} 34^{+}$agrupadas por idade no terceiro dia de cocultivo

Figura 12- Percentagem de células Lin ${ }^{-C D} 34^{+}$agrupadas por idade no sétimo dia de co-cultivo

Figura 13- Percentagem de células Lin ${ }^{-C D} 34^{+}$agrupadas por idade no sétimo dia de co-cultivo com CTMs de diferentes idades por 3 dias

Figura 14- Percentagem da subpopulação CD34+ após o co-cultivo de CTHs com CTMs de diferentes idades por 3 dias

Figura 15- Percentagem de células da subpopulação CD34+ após o co-cultivo de CTHs com CTMs de diferentes idades por 7 dias

Figura 16- Quantidade de CXCL-12 secretada no sobrenadante dos co-cultivos de CTHs com

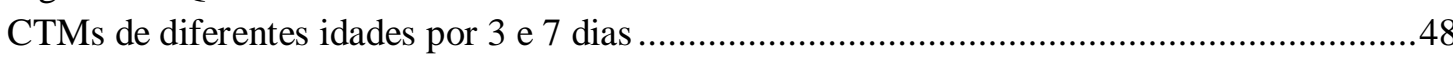

Figura 17- Estratégia de análise do receptor CXCR-4 em CTHs.............................................51

Figura 18- Expressão de CXCR-4 em CTHs de indivíduos de diferentes idades .....................52

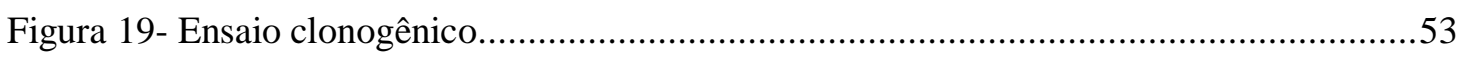

Figura 20- Formação de colônias mielóides de CTHs co-cultivadas com CTMs ......................54

Figura 21- Formação de colônias mielóides de CTHs co-cultivadas com CTMs de diferentes

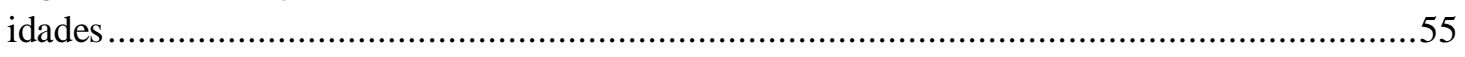

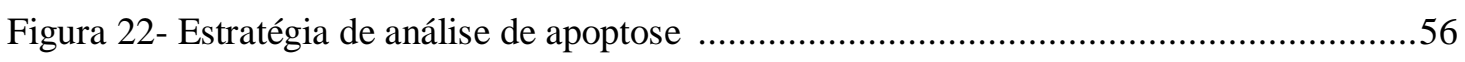

Figura 23- Análise de morte celular de CTHs co-cultivadas com CTMs de diferentes idades por 7 dias 


\section{LISTA DE ABREVIATURAS}

CTHs Células-tronco hematopoéticas

MO Medula óssea

CLP Progenitor linfóide comum (do inglês, common lymphoid progenitor)

CMP Progenitor mielóide comum (do inglês, common myeloid progenitor)

MEP Progenitor megacariocítico/eritrocítico (do inglês, megacaryocyte/erytocyte)

GMP Progenitor granulocítico/macrofágico (do inglês, granulocyte/macrophage)

MkP Progenitor megacariocítico (do inglês, megacaryocyte progenitor)

EP Progenitor eritrocítico (do inglês, erytrocyte progenitor)

GP Progenitor granulocítico (do inglês, granulocyte progenitor)

MaCP Progenitor macrofágico (do inglês, macrophage progenitor)

NK Natural Killer

DPP Proteína decapentaplégica (do inglês, decapentaplegic protein)

BMP2/4 Proteína morfogênica do osso (do inglês, bone morphogenic protein)

Ob Osteoblastos

SDF-1 Fator derivado de célula-tronco estromal (do inglês, stromal-cell derived factor -1)

SCF Fator de célula-tronco (do inglês, stem cell factor)

CAR Células reticulares abundantes em CXCL-12 (do inglês, CXCL-12 abundant reticular cells)

G-CSF Fator estimulador de colônia granulocítica (do inglês, granulocyte colonystimulating factor)

PTHr Receptor de hormônio paratireoideo (do inglês, parathyroid hormone receptor)

PTH Hormônio paratireoideo (do inglês, parathyroid hormone)

SNO Células imaturas da osteolinhagem de formato fusiforme $\mathrm{N}$-caderina positivas e CD45 negativas (do inglês, spindle-shaped N-cadherin+ CD45-)

Ang-1 Angiopoetina-1 (do, inglês angiopoetin-1)

CTMs Células-tronco mesenquimais

CFU-F Unidade formadora de colônia fibroblástica (do inglês, colony-forming unit fibroblastic)

SMaA Marcador de células do músculo liso (do inglês, smooth muscle a actin) 
PDGFR Receptor do fator de crescimento derivado de plaquetas (do inglês, platelet-derived growth factor receptors)

VCAM-1 Molécula de adesão celular vascular-1 (do inglês, vascular cell adhesion molecule-1)

GFP Proteína verde fluorescente (do inglês, green fluorescente protein)

MCAM Molécula de adesão celular associada ao melanoma (do inglês, melanomaasscociated cell adhesion molecule)

CMN+ Células mesenquimais nestina+

SNS Sistema Nervoso Simpático

CE Células endoteliais

SLAM Molécula de ativação de sinalização linfocítica

TGF- $\beta \quad$ Fator de crescimento transformador $-\beta$ (do inglês, transforming-growth factor $-\beta$ )

HGF Fator de crescimento de hepatócito (do inglês, hepatocyte growth factor)

TPO Trombopoetina

Wnt Wingless

SDF-1 Fator estromal 1 (do inglês, stromal cell-derived factor - 1)

DMEM Meio de cultura (do inglês, Dulbecco's Modified Eagle Medium)

SFB Soro fetal bovino

LMN Células linfomononucleares

DPBS Tampão fosfato sem cálcio e magnésio (do inglês, Dulbecco's PhosphateBuffered Saline)

P Passagem

C1 Tampão de lavagem para citometria 


\section{LISTA DE SÍMBOLOS}

$\begin{array}{ll}\boldsymbol{\mu g} & \text { Micrograma } \\ \boldsymbol{\mu L} & \text { Microlitro } \\ { }^{\circ} \mathbf{C} & \text { Grau Célsius } \\ \mathbf{c m} & \text { Centímetro } \\ \mathbf{g} & \text { Força Centrifuga Relativa } \\ \mathbf{m L} & \text { Mililitros } \\ \mathbf{n g} & \text { Nanograma }\end{array}$




\section{RESUMO}

Benedito SS. Influência do envelhecimento das células-tronco mesenquimais na autorrenovação, diferenciação e multipotência de células-tronco hematopoéticas [Dissertação]. São Paulo: Faculdade de São Paulo, Universidade de São Paulo; 2016.

O envelhecimento é um processo gradual e intrínseco que ocorre devido a mudanças fisiológicas e fenotípicas com o avanço da idade e que acarreta na diminuição da capacidade de manter a homeostase e reparo tecidual. A perda do controle homeostático e o possível envolvimento de células-tronco e progenitores, provavelmente, é uma das causas das fisiopatologias do sistema hematopoético que acompanham o envelhecimento. O declínio na competência do sistema imune adaptativo, o aumento de doenças mielóides, leucemias e o desenvolvimento de anemias são algumas mudanças significantes e decorrentes do processo de envelhecimento. Durante a transição ontológica, a habilidade de células-tronco hematopoéticas originarem células progenitoras diminui progressivamente, sugerindo perda da capacidade de autorrenovação e diferenciação das células-tronco com o avanço da idade. O microambiente medular se divide em duas áreas distintas: nicho endosteal e nicho vascular, conhecidos por controlar a homeostase das células-tronco hematopoéticas; e é composto por uma mistura heterogênea de células, dentre elas as células-tronco mesenquimais que expressam moléculas que controlam algumas funções das células-tronco hematopoéticas. De acordo com estas observações, este trabalho investiga o papel do envelhecimento das células-tronco mesenquimais no processo de autorrenovação, multipotência e diferenciação das células-tronco hematopoéticas. Neste trabalho, avaliamos a percentagem de células-tronco hematopoéticas $\operatorname{Lin}^{-C D} 34^{+}$e subpopulações em co-cultura com células-tronco mesenquimais derivadas de medula óssea de diferentes idades, bem como sua capacidade de autorrenovação, diferenciação, secreção da quimiocina CXCL-12 e a expressão do receptor CXCR-4. Nossos resultados mostraram diferenças significativas nos parâmetros fenotípicos e funcionais das células-tronco hematopoéticas co-cultivadas com célulastronco mesenquimais de doadores idosos. Estes dados sugerem que o envelhecimento das células-tronco mesenquimais podem influenciar na homeostase do microambiente medular.

Descritores: nicho de células-tronco; células-tronco hematopoéticas; células-tronco; medula óssea; células-tronco mesenquimais; envelhecimento. 


\begin{abstract}
Benedito SS.Mesenchymal stem cells aging influence in the self-renewal, differentiation and multipotency of hematopoietic stem cells [Dissertation]. São Paulo: "Faculdade de São Paulo, Universidade de São Paulo"; 2016.
\end{abstract}

Certainly, aging is one of the best identified features of the human biology, and is also the least understood. This is largely attributed to the fact that aging is gradual and fundamentally complex, due to all modifications in the physiological and phenotypic aspects occurred during the age advancing. One of the most striking features of aging is the decreased ability to maintain homeostasis and tissue repair. Consistent with those findings, many of the pathophysiological conditions affecting aging, such as anemia, dysplasia, leukemia and anemia suggest an imbalance between cell losses and the ability to self-renew or differentiation. The decline in homeostatic maintenance and regenerative potential of tissues during aging has been associated with changes in stem cells. Increasing evidences point to the stem cells as major accountable for the aging pathophysiology in several tissues. Thus, studies in mammals comprise a careful evaluation of mechanisms connected to stem cells. The increasing age is accompanied by many pathophysiological changes in the hematopoietic system wherein the etiology suggests loss of homeostatic control and a possible involvement of stem and progenitor cells. The clinically relevant changes are related to adaptive immune system diminished competence, the increase of myeloid diseases including leukemia and the onset of anemia in the elderly. The hematopoietic stem cell microenvironment is located in the bone marrow and is divided in two domains: the endosteal niche near to the bone surface and vascular niche associated with the sinusoidal endothelium; the niche consist of several heterogeneous cells types, among them, the mesenchymal stem cells. The mesenchymal stem cells express molecules that control hematopoietic stem cells functions. Therefore, this study investigates the role of mesenchymal stem cells aging in the self-renewal, multipotency and differentiation of hematopoietic stem cells. This study evaluated the percentage of hematopoietic stem cell Lin-CD34+ and subpopulations in co-culture with mesenchymal stem cell bone marrow-derived from donors with different ages, their ability of self-renewal, differentiation, secretion of chemokine CXCL-12 and expression of the CXCR-4 receptor. Our results suggest that the mesenchymal stem cells aging can affect the bone marrow niche homeostasis. 
Descriptors: stem cell niche; hematopoietic stem cells; stem cells; bone marrow; mesenchymal

stem cells; aging. 


\title{
SUMÁRIO
}

\author{
LISTA DE FIGURAS \\ LISTA DE TABELAS \\ LISTA DE ABREVIATURAS \\ LISTA DE SÍMBOLOS \\ RESUMO
}

ABSTRACT

SUMÁRIO

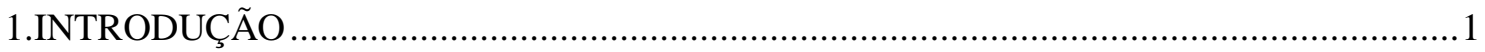

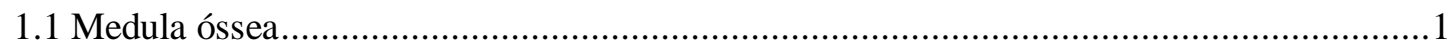

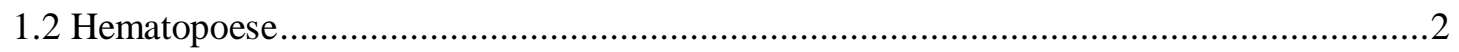

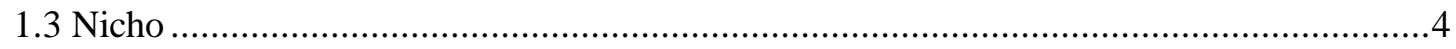

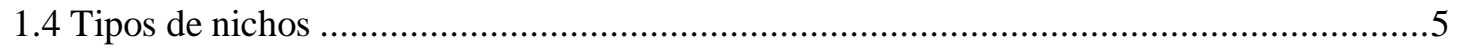

1.5 Componentes celulares dos nichos endosteal e vascular ................................................

1.5.1 Nicho endosteal: osteoblastos, células SNO e osteoclastos ...........................................

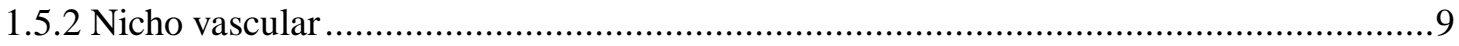

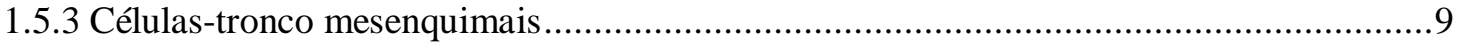

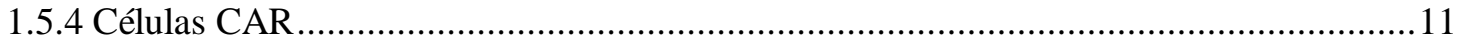

1.5.5 Células mesenquimais Nestina ${ }^{+}$e Leptina $^{+}$............................................................. 13

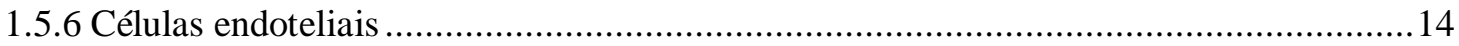

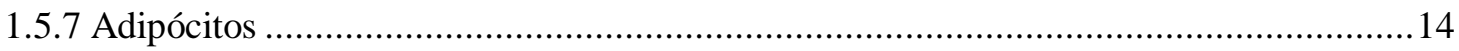

1.5.8 Sistema nervoso simpático e células da glia (Schwann) ............................................15

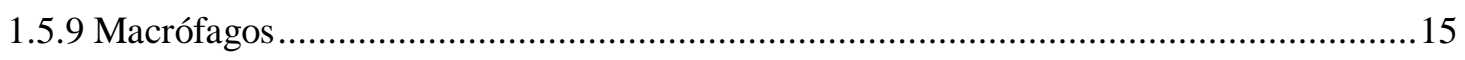

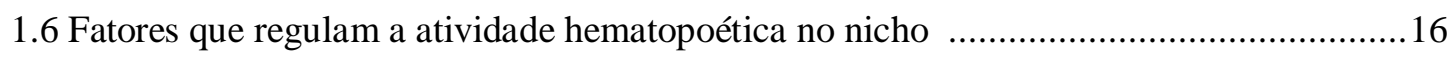

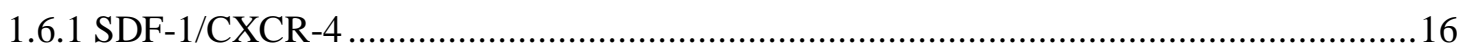

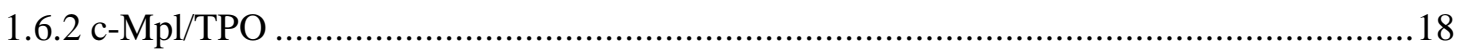

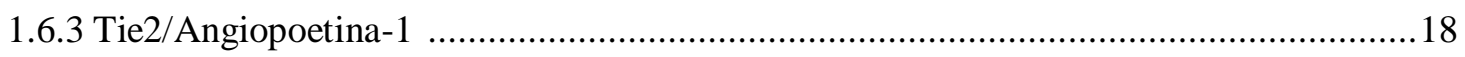

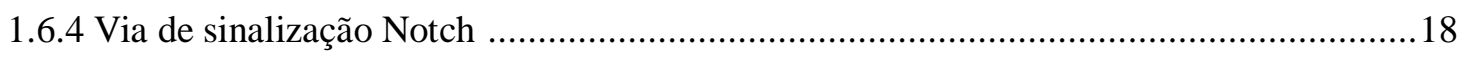

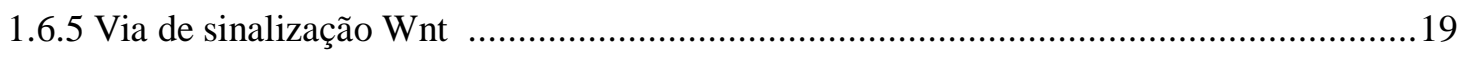

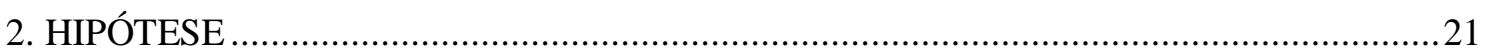

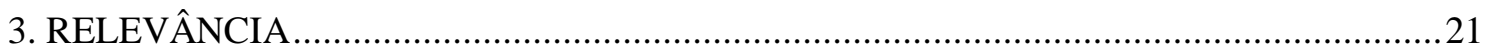

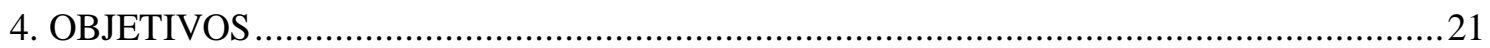

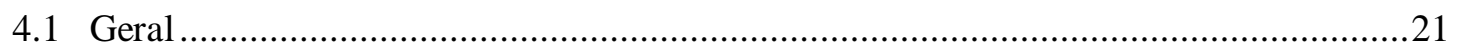

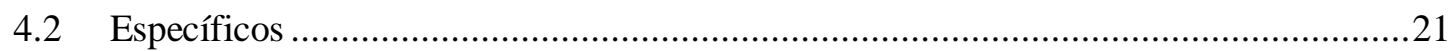




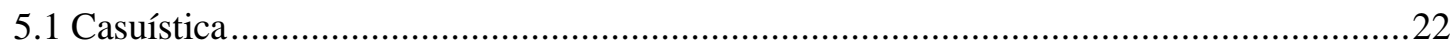

5.2 Obtenção, cultivo e manutenção de células-tronco mesenquimais ...................................36

5.3 Caracterização imunofenotípica das células-tronco mesenquimais

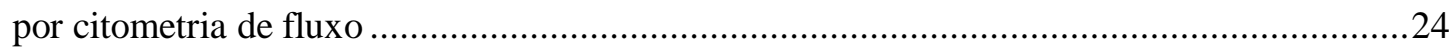

5.4 Diferenciação das células-tronco mesenquimais.............................................................24

5.4.1 Protocolo de diferenciação adipogênica ……........................................................25

5.4.2 Protocolo de diferenciação osteogênica ..................................................................25

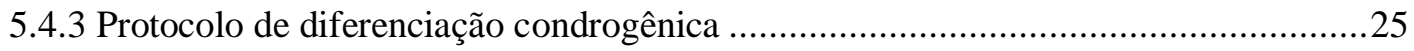

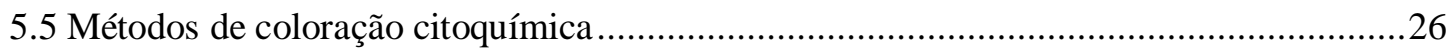

5.6 Obtenção de células linfomononucleares de SCU.........................................................27

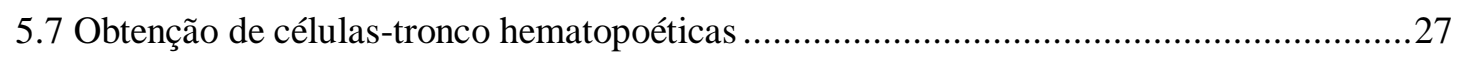

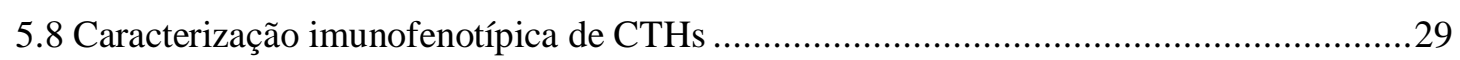

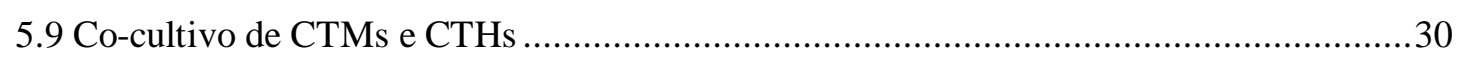

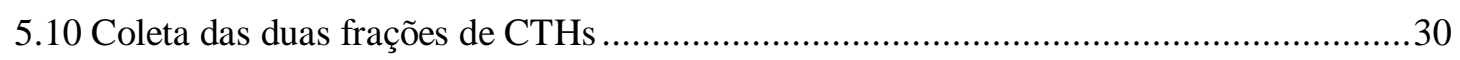

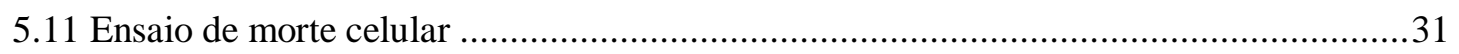

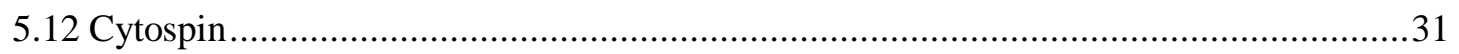

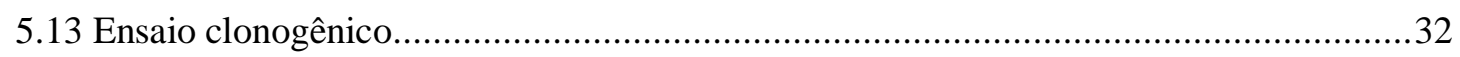

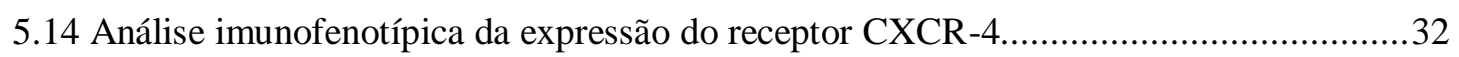

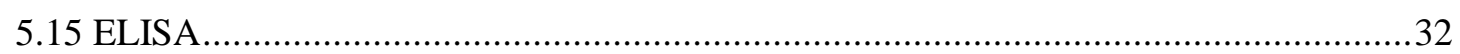

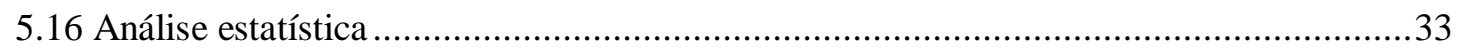

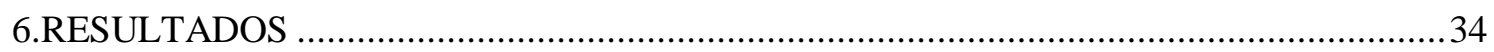

6.1 Caracterização de CTMs da MO e CTHs provenientes de SCU ........................................34

6.1.1 As CTMs isoladas preencheram todos os requisitos da

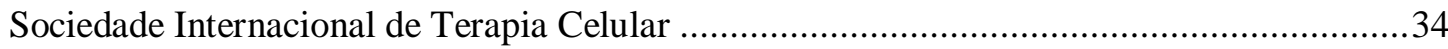

6.1.2 As CTHs isoladas eco-cultivadas com CTMs apresentam

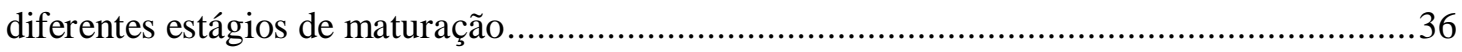

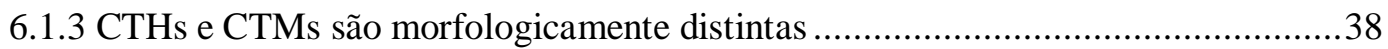

6.2 Co-cultivo das CTHs de SCU com CTMs provenientes de doadores de MO ..................38

6.2.1 O co-cultivo de CTMs com CTHs favoreceu a manutenção da população de células indiferenciadas Lin-CD34+, após sete dias de cultivo...........................39

6.2.2 Não foram observadas diferenças significativas da população de células Lin-CD34+ após três dias de cultivo, quando as CTMs foram agrupadas por idade 
6.2.3 O co-cultivo de CTHs com CTMs favoreceu a manutenção

da população de células indiferenciadas Lin-CD34+ na fração A após sete dias

de cultivo quando CTMs foram agrupadas por idade

6.2.4 CTMs mantém subpopulações de CTHs com perfil mais indiferen-

ciado no terceiro e sétimo dia de cultivo

6.2.5 CTMs de doadores de diferentes idades mantêm o estado indiferen-ciado de CTHs, após o terceiro e sétimo dia de cultivo.

6.2.6 O co-cultivo de CTHs com CTMs de doadores de diferentes ida-

des influenciaram na quantidade de CXCL-12 no sobrenadante do terceiro e sétimo dia de cultivo

6.2.7 Estratégia de análise do receptor CXCR-4

6.2.8 Expressão do receptor CXCR-4 diminui em CTHs de doado-

res idosos

6.2.9 Ensaio clonogêncio de CTMs co-cultivadas com CTMs de doadores de diferentes idades

6.2.10 CTHs co-cultivadas com CTMs formaram maior número de colônias

6.2.11 CTHs co-cultivadas com CTMs do grupo de 0-20 anos formaram mais colônias

6.2.12 Estratégia de análise de apoptose

6.2.13 Na análise de apoptose, não foram observadas diferenças

significativas entre as frações S e A quando comparadas ao controle ou nos co-cultivos com

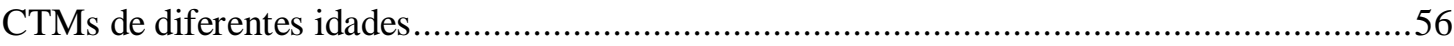

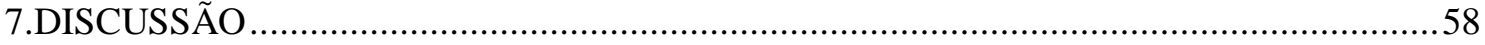

8.CONCLUSÃO

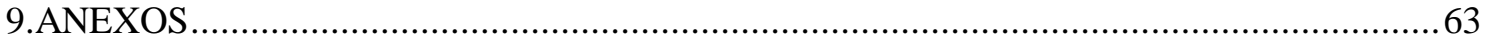

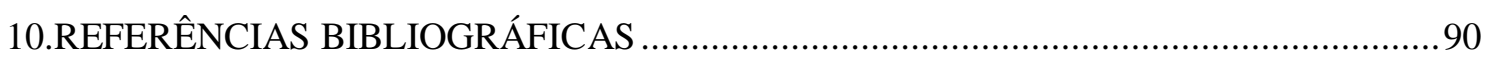




\section{1- Introdução}

O envelhecimento é uma das características melhor identificada na biologia humana, entretanto, também é uma das menos compreendida. Isso é largamente atribuído ao fato de o processo de envelhecimento ser gradual e intrinsecamente complexo, devido a todas as modificações sofridas nos aspectos fisiológicos e fenotípicos com o avanço da idade.

Uma das características mais marcantes do envelhecimento é a diminuição da capacidade do organismo manter a homeostase e o reparo tecidual. Diante desta afirmação, muitas das condições fisiopatológicas que afetam os indivíduos durante o envelhecimento, como a anemia, sarcopenia e osteoporose, sugerem um desequilíbrio entre a perda celular e a capacidade de autorrenovação. O declínio da manutenção homeostática e do potencial regenerativo dos tecidos durante o envelhecimento tem sido relacionado com alterações na biologia das células-tronco.

$\mathrm{O}$ avanço da idade é acompanhado por muitas mudanças fisiopatológicas no sistema hematopoético, no qual a etiologia sugere perda do controle homeostático e o possível envolvimento das células-tronco e progenitoras. As mudanças mais clinicamente significantes são o declínio na competência do sistema imune adaptativo (1), aumento das doenças mielóides $(2,3)$ e leucemias (4), e o desenvolvimento de anemias (5).

As células-tronco hematopoéticas (CTHs) são células-tronco adultas encontradas na medula óssea que apresentam a capacidade de se autorrenovarem, ou seja, originam duas células filhas idênticas à célula mãe; e também têm a capacidade de se diferenciarem para dar origem às células sanguíneas (6).

A habilidade das CTHs originarem células progenitoras diminui substancialmente durante a transição ontológica do fígado fetal para o sangue de cordão e a medula óssea adulta (7), sugerindo uma perda progressiva do potencial de autorrenovação e diferenciação das células-tronco com o avanço da idade.

\subsection{Medula óssea}

A medula óssea (MO) é o órgão hematopoético localizado no interior das cavidades medulares dos ossos onde ocorre a hematopoese. No período pré-natal até o nascimento a medula formadora de células sanguíneas está distribuída em quase todos os ossos do organismo. Esta é muito vascularizada e possui uma cor vermelho-escura, por 
isso é denominada medula vermelha. Conforme o desenvolvimento da criança até a fase adulta a MO se restringe apenas aos ossos chatos como o esterno, crista ilíaca e costelas. Ao envelhecer, alguns ossos perdem a função de produzir células sanguíneas. Nesta fase há substituição do tecido hematopoético por tecido adiposo, o qual apresenta cor amarelada, passando a ser chamada de medula amarela.

A MO, cuja morfologia está representada na Figura 1, contém uma rede densa de vasos sanguíneos onde as CTHs e as células progenitoras residem em um complexo microambiente, conhecido como nicho, o qual é composto por diferentes tipos de células que oferecem sinais essenciais para manter a homeostase do sistema hematopoético e a manutenção, proliferação e diferenciação das células sanguíneas maduras durante toda a vida (8).

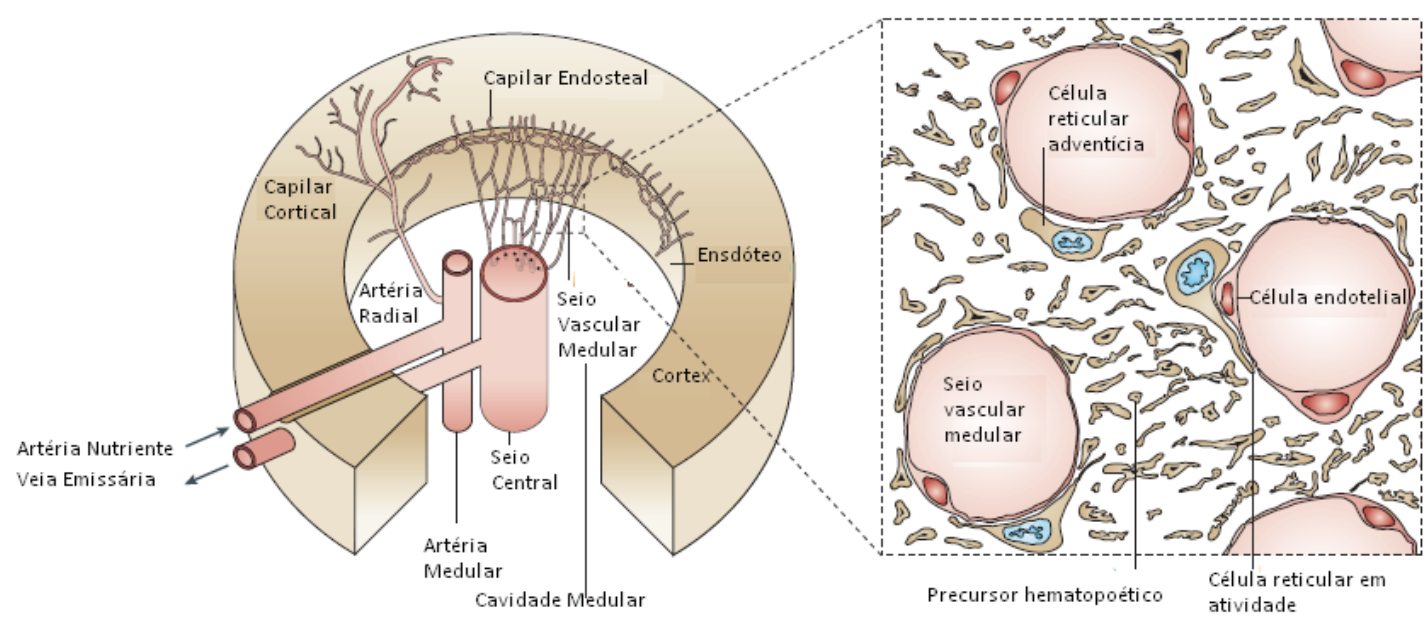

Figura 1 - Morfologia da medula óssea - A MO está localizada na cavidade central do osso e sua principal fonte de sangue é proveniente da artéria nutriente, a qual atravessa o córtex através do canal nutriente para o interior da cavidade medular dividindo-se em artéria ascendente e descendente, e a partir destas artérias surgem as artérias radiais. Estas entram no córtex pelo endósteo, revestem a cavidade medular e tornam-se capilares corticais, os quais formam uma rede densa na cavidade medular. Os seios eventualmente recolhem e adentram o seio central por onde o sangue deixa a medula. Os seios vasculares medulares estão alinhados com células endoteliais e cercados por células reticulares adventícias. A hematopoese acontece nos espaços extravasculares entre os seios (Adaptado de Nagasawa, 2006) (9). 


\subsection{Hematopoese}

A hematopoese é um processo contínuo de produção de células sanguíneas que ocorre através da autorrenovação, proliferação e diferenciação das CTHs na MO. Depois de diferenciadas, as células ganham a circulação com a função de manter a homeostase sanguínea (10).

Durante o desenvolvimento, a hematopoese ocorre sequencialmente em localizações anatômicas distintas. Ela pode ser dividida em dois estágios: o primitivo e o definitivo.

A hematopoese primitiva ocorre no período embrionário, antes do desenvolvimento do fígado fetal, e está localizada no saco vitelino, aorta gônada mesonéfrica e placenta. Já o estágio definitivo inicia-se na $4^{\mathrm{a}}$ e termina na $24^{\mathrm{a}}$ semana gestacional; neste período, denominado hepatoesplênico, as células hematopoéticas estão presentes no fígado e baço fetal. A partir da $24^{\text {a }}$ semana gestacional, os ossos esponjosos do feto passam a ser colonizados por CTHs provenientes do fígado e do baço e esse período é reconhecido como período medular (3).

Em adultos saudáveis, cerca de $1 \times 10^{12}$ células sanguíneas são produzidas diariamente pelas CTHs que residem na MO (11). O processo de produção do sangue (Figura 2) é iniciado a partir de uma célula pluripotente com capacidade de se autorrenovar e se diferenciar em células progenitoras multipotentes. Estas células originam progenitores oligopotentes que podem estar comprometidos com a linhagem mielóide ou linfóide.

Os progenitores mielóides comuns se diferenciam em células da linhagem mielóide, tais como: monócitos, eritrócitos, megacariócitos, granulócitos, macrófagos e células dendríticas. Progenitores linfóides comuns dão origem aos linfócitos T e B, células Natural Killer (NK) e células dendríticas de origem linfóide (12). 


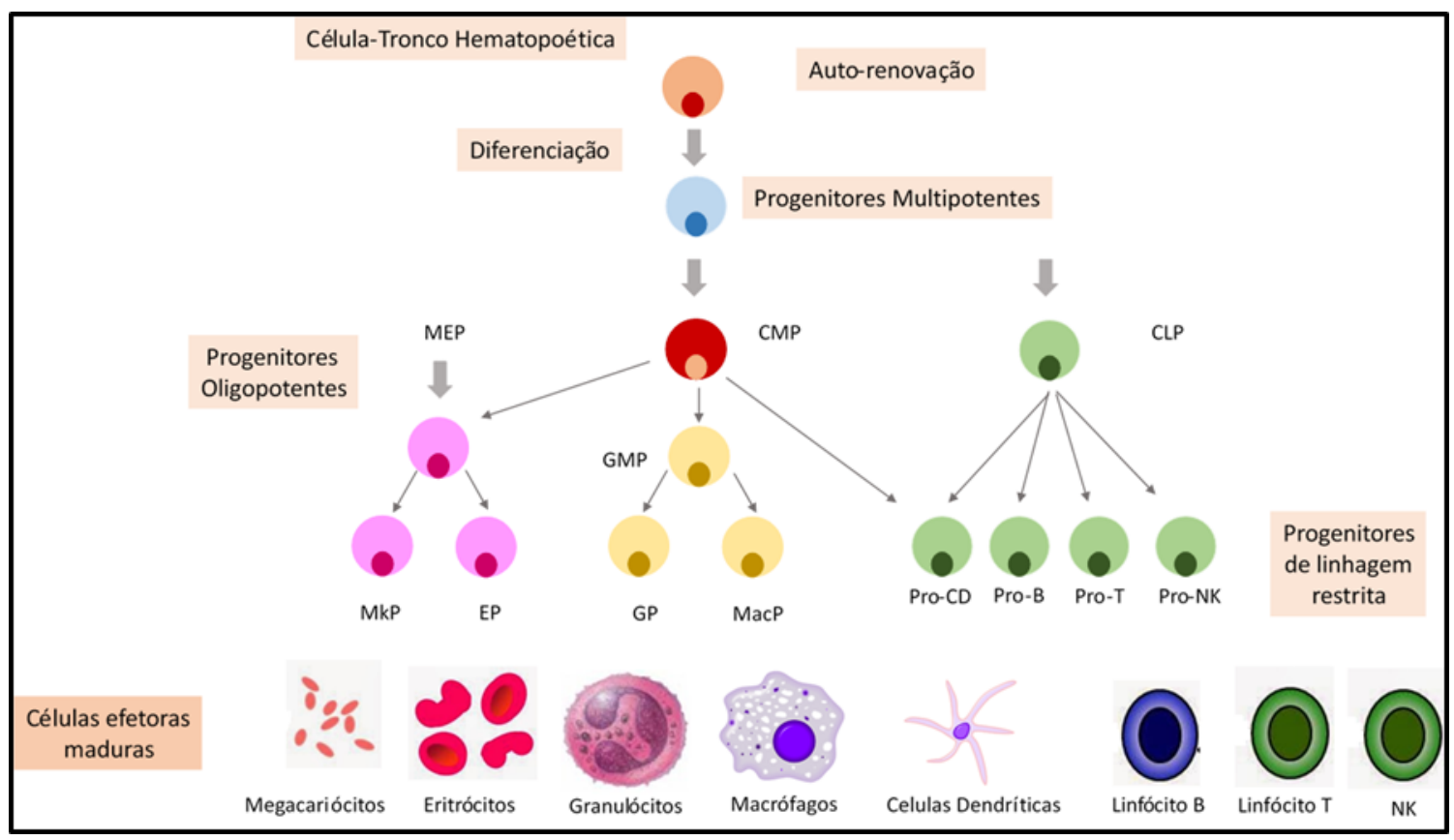

Figura 2- Desenho esquemático da hematopoese. CLP (do inglês, common lymphoid progenitor); CMP (do inglês, common myeloid progenitor); MEP (do inglês, megakaryocytelerythrocyte progenitor); GMP (do inglês, granulocyte/macrophage progenitor); MkP (do inglês, megakaryocyte progenitor); EP (do inglês, erythrocyte progenitor); GP (do inglês, granulocyte progenitor); MaCP (do inglês, macrophage progenitor); NK (do inglês, Natural Killer) (adaptado de Kamonnaree et al, 2012) (12).

\subsection{Nicho}

Células-tronco e progenitores hematopoéticos estão localizados em microambientes na MO conhecidos como nichos, que fornecem a estas células sinais reguladores indispensáveis para a manutenção, proliferação e diferenciação celular.

Desde a década de 70 inúmeros estudos foram realizados com objetivo de elucidar o papel do nicho e seus componentes celulares e moleculares. Lord e colaboradores em 1975 observaram que as cavidades de ossos longos continham células primitivas localizadas próximas às margens endosteais, sugerindo uma provável participação das células do tecido ósseo na hematopoese (13). Em 1977 Dexter e colaboradores cultivaram células primitivas hematopoéticas em um sistema de cultura, in vitro, no qual estas células proliferaram por vários meses (14). Tais culturas consistiam em células aderentes e nãoaderentes. A população de células aderentes inclui células como osteoblastos, células endoteliais e macrófagos as quais deram suporte à hematopoese $(14,15)$.

Porém, o conceito de nicho de célula-tronco foi proposto por Schofield em 1978; ao realizar um transplante em camundongos irradiados utilizando células derivadas da 
MO e do baço, notou-se que as células da MO eram mais eficientes do que as do baço na reconstituição hematopoética, sugerindo que estas células tinham a habilidade de reconstituição hematopoética preservada, sendo então considerado o microambiente destas células (16). Duas décadas depois Xie e Spradling mostraram que células-tronco da linhagem germinativa que residiam o ovário da Drosophila melanogesters estavam rodeadas por diferentes células-tronco somáticas que através da proteína decapentaplégica (dpp), que é homóloga à proteína morfogênica do osso (BMP-2/4) expressa por um subtipo de células foliculares, controla a manutenção, sobrevivência e proliferação da linhagem germinativa da fêmea dessa espécie (17).

Vários estudos sugerem a existência de dois tipos de nichos especializados que durante todo o desenvolvimento são responsáveis pela manutenção das CTHs, as quais são reguladas principalmente por fatores intrínsecos em uma complexa rede de moléculas de sinalização e fatores de crescimento.

Acredita-se que estes nichos estão localizados em uma arquitetura especial na MO onde as CTHs podem ser encontradas na região endosteal (nicho osteoblástico) ou próximas ao endotélio sinusoidal (nicho perivascular). Um ponto importante sugerido pelo trabalho de Oh e Kwon, é a existência destes dois nichos com funções e interações celulares distintas (18). Neste estudo, utilizando imagem in vivo em tempo real, revelouse que CTHs imaturas, quando transplantadas migravam para a região endosteal, enquanto os subtipos mais maduros residiam mais distante do endósteo (18).

Além das células hematopoéticas, os nichos são compostos por diferentes tipos de células que contribuem para a homeostase óssea e para a regulação da hematopoese (19).

\subsection{Tipos de nichos}

As CTHs localizam-se em dois nichos distintos na MO, o endosteal e o vascular. Os nichos são complexos e abrangem uma ampla variedade de células incluindo as da linhagem óssea (osteoblasto e osteoclastos), células-tronco mesenquimais, endotélio sinusoidal, células perivasculares estromais, células imunes e outras que têm diferentes funções na regulação das CTHs (18).

O nicho endosteal está localizado na superfície da cavidade da MO que é composta pelo osso cortical e trabecular. A superfície dos ossos é revestida por células da linhagem óssea tais como os osteoblastos $(\mathrm{Ob})$ e osteoclastos. Os Ob são células progenitoras que 
agem juntamente aos osteoclastos no processo de formação óssea chamada osteogênese (20).

O nicho vascular ou sinusoidal é composto por vasos sinusóides de paredes finas, revestidos por uma camada única de endotélio, e servem como meio de comunicação entre a cavidade óssea e a circulação. Células como reticulares adventícias, estromais perivasculares, mesenquimais e neurais estão associadas aos vasos sinusóides formando um nicho que sustenta e regula as CTHs (20).

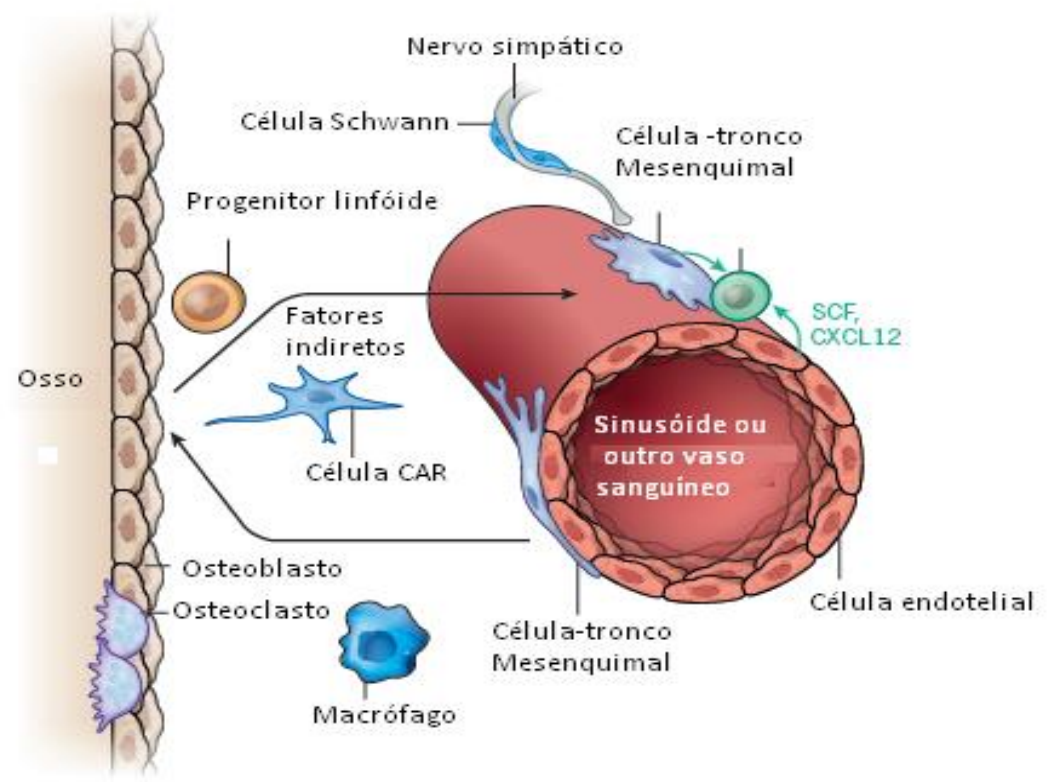

Figura 3 - Células-tronco hematopoéticas e células progenitoras hematopoéticas restritas ocupam distintos nichos na MO (Adaptado de Morrison et al, 2014) (21).

As CTHs estão localizadas principalmente adjacentes aos vasos sinusóides por toda a MO $(22,23,24,25)$, onde células endoteliais e mesenquimais promovem a manutenção das CTHs pela produção de fator de célula-tronco SCF, (do inglês, stem cell factor) (26), CXCL-12 $(25,27,28)$ e provavelmente outros fatores. Células similares também podem promover a manutenção das CTHs ao redor de outros vasos sanguíneos, como arteríolas. As células estromais perivasculares, como as células CAR (do inglês, CXCL-12 abundant reticular cells) (25), estão comprometidas com a formação óssea (29). Outros tipos de células também podem participar da regulação do nicho, como as do nervo simpático $(30,31)$, células não mielinizantes de Schwann, as quais também são nestina positivas $\left(\mathrm{Nes}^{+}\right)$(32), macrófagos (33) e osteoclastos (34). Ob promovem a 
manutenção e talvez a diferenciação de certos progenitores linfóides por secretarem CXCL-12 e outros fatores $(27,35,36,37)$.

\section{5-Componentes celulares dos nichos endosteal e vascular}

\subsection{1- Nicho endosteal: Osteoblastos, células SNO e osteoclastos}

Estudos realizados na década de 70 mostraram que as células hematopoéticas indiferenciadas estão localizadas próximas à superfície do osso endosteal. Entretanto, na literatura, há trabalhos que evidenciam a existência de outros tipos de células que estão próximas a esta região e que parecem ter um papel importante na regulação das CTHs. Dentre elas podemos citar as células da linhagem osteoblástica, presentes na superfície óssea e que está envolvida na síntese, deposição e, mineralização da matriz extracelular óssea.

A primeira evidência direta de que $\mathrm{Ob}$ humanos participavam da hematopoese foi demonstrada em 1994 por Taichman e colaboradores (35). Estes pesquisadores mostraram que os $\mathrm{Ob}$ mantiveram a proliferação in vitro de progenitores hematopoéticos através da produção de fator estimulador de colônia granulocítica - G-CSF (do inglês, granulocyte colony-stimulating factor) (35). A ativação dos Ob parece estar envolvida com a ligação do hormônio paratireoídeo aos seus receptores. Para avaliar o quanto as células osteoblásticas regulavam as CTHs, Calvi e colaboradores, 2003 trataram camundongos com o hormônio paratireoídeo e observaram aumento na produção do ligante de Notch (Jagged1) e no número de CTHs in vivo (38).

Além disso, a ativação do receptor de hormônio paratireoídeo (PTHr, do inglês, parathyroid hormone receptor) pelo hormônio paratireoídeo (PTH, do inglês parathyroid hormone) aumentou o número de $\mathrm{Ob}$ mantidos em cultura com células do estroma. Baseando-se nesses dados, os pesquisadores sugeriram que as células osteoblásticas são importantes componentes reguladores do nicho das CTHs in vivo e que influenciam a função da célula-tronco através da ativação da via de sinalização Notch. (38).

Outros estudos apontam que a linhagem osteoblástica produz fatores importantes que estão envolvidos na retenção e manutenção das CTHs, incluindo a quimiocina CXCL-12 (39, 40), osteopoetina (41), N-caderina e fatores que mantêm o estado 
quiescente destas células como a angiopoetina-1 (Ang-1, do inglês, angiopetin-1) (42), o ligante de membrana SCF e a trombopoetina (43).

A contribuição da N-caderina na manutenção das CTHs ainda é desconhecida. As caderinas são moléculas de adesão que formam as junções aderentes entre células vizinhas. Elas são expressas em subtipos celulares da linhagem osteoblástica, principalmente em células SNO (do inglês, spindle-shaped $\mathrm{N}$-cadherin ${ }^{+}$CD45-negativas) que são células imaturas da osteolinhagem de formato fusiforme $\mathrm{N}$-caderina positivas e CD45 negativas (44).

Zhang e colaboradores, (2003) demonstraram aumento no número das CTHs que estavam em contato com as células $\mathrm{SNO}$, as quais expressam altos níveis de $\mathrm{N}$-caderina sugerindo então a importância desta molécula na manutenção das CTHs (45).

Quando a expressão de N-caderina nas CTHs foi inibida pelo grupo de Hosakawa, observou-se que as células não perdiam sua capacidade de migração (homing) para o nicho, porém tinham a capacidade de residência (lodgment) reduzida e aceleração do ciclo celular (46). Já a super-expressão da N-caderina nas CTHs levou ao aumento na quiescência e redução na capacidade de divisão celular (47). Estes estudos mostraram uma estreita relação da N-caderina com a adesão celular e a quiescência. Entretanto, alguns autores reportaram a baixa expressão de $\mathrm{N}$-caderina pelas CTHs e que sua presença não foi necessária para a manutenção das CTHs $(46,47,48,49)$. Quando a deleção de Cdh2 (N-caderina) foi realizada na linhagem osteoblástica, não foram observadas diferenças significativas no número, tráfego, ciclo celular e atividade de repopulação das CTHs $(50,51)$.

É importante ressaltar que a N-caderina apresentou efeitos contrastantes nas CTHs e pouca importância na linhagem óssea. Entretanto, tal fato não descarta o papel das células SNO na regulação das CTHs no nicho.

Visnjic e colaboradores, (2004) observaram em um modelo murino transgênico, o qual apresentava a linhagem osteoblástica removida, uma variedade de alterações na MO. Dentre elas podemos citar alterações na formação óssea, ocasionando perda óssea progressiva e redução no número de células na MO. Neste estudo os pesquisadores avaliaram a perda de células progenitoras da linhagem linfóide, mielóide, eritróide e a redução do número de CTHs. Observou-se também hematopoese extramedular, no baço 
e fígado, e aumento das CTHs no sangue periférico. Estas observações demonstraram a importância da linhagem osteoblástica na hematopoese, bem como o seu papel na retenção de progenitores hematopoéticos na MO (36).

Os osteoclastos são gerados pelas células CTHs e sua principal função é a reabsorção da matriz óssea mineralizada formada por condrócitos ou Ob. O papel dos osteoclastos na hematopoese ainda é controverso; tem sido relatado que os osteoclastos degradam componentes do nicho endosteal e aumentam a mobilização de células progenitoras hematopoéticas para a periferia (52). Por outro lado, células da linhagem osteoblástica são essenciais para a manutenção das CTHs no nicho medular, pela produção de citocinas, quimiocinas e moléculas de adesão que regulam o destino das CTHs. A administração de G-CSF diminui temporariamente o número destas células, levando a uma pronunciada diminuição na formação óssea e mineralização no endósteo e reduzida expressão de CXCL12 e Ang-1 na MO. Esta inibição do nicho endosteal coincide com a mobilização das CTHs, que não foi mediada por osteoclastos, mas por uma perda do suporte dos Ob e macrófagos. A depleção in vivo de macrófagos em dois modelos não relacionados levou à depleção de osteoblasto e causou uma robusta mobilização de CTHs para o sangue periférico. Estes dados mostraram que macrófagos da MO têm papel crítico na manutenção endosteal das CTHs no nicho (33). Portanto, estes estudos sugerem que as linhagens osteoblásticas, macrófagos e células SNO, participam da regulação do nicho endosteal influenciando a função das CTHs.

\subsection{2- Nicho vascular}

\subsection{3 - Células-tronco mesenquimais}

As células-tronco mesenquimais (CTMs) ou células-tronco estromais são células precursoras que se autorrenovam e podem se diferenciar em células da linhagem osteogênica, adipogênica e condrogênica. Estudos recentes sugerem que as CTMs possuem um papel importante na formação do nicho e na manutenção das CTHs. A facilidade de isolar CTMs e células progenitoras estromais da MO e de outros tecidos levou a um rápido desenvolvimento na investigação clínica, explorando suas propriedades anti-inflamatórias, capacidade de preservação tecidual e potencial regenerativo. 
Há mais de 40 anos Alexander Friedentstein descreveu que células precursoras estromais multipotentes eram capazes de formar o tecido ósseo existente na MO (52) e que ao isolarem e semearem estas células, as mesmas foram capazes de aderir ao plástico e formar colônias fibroblásticas (CFU-F, do inglês colony-forming unit fibroblastic) derivadas de uma única célula. O potencial de autorrenovação e diferenciação foram demonstrados in vivo por transplantes $(53,54)$, sugerindo então a presença de célulastronco estromais na MO.

Caplan, (1991) denominou de células-tronco mesenquimais, as células precursoras adultas da MO que eram capazes de se diferenciarem em células do tecido ósseo, cartilaginoso e outros tecidos mesodérmicos (55).

A Sociedade Internacional de Terapia Celular propôs um critério mínimo para caracterizar as CTMs. Com isso, estas células devem apresentar as seguintes características: serem aderentes ao plástico; expressarem os marcadores de superfície CD105, CD90 e CD73, mas não expressarem os marcadores HLA de classe II (HLADR), pan-leucocitário (CD45), endotelial (CD31), células primitivas hematopoéticas (CD34), monócitos (CD14 ou CD11b) e células B (CD79a ou CD19). Além disso, as CTMs devem ser capazes de se diferenciarem em Ob, condrócitos e adipócitos (52). Apesar da evidência de que as CTMs podem se diferenciarem em vários tipos de células, in vitro e in vivo, a contribuição real destas células para a reparação tecidual ainda não está bem esclarecida (71).

Um estudo recente mostrou que as CTMs humanas, originadas da MO, podem expressar um marcador denominado molécula de adesão celular associado ao melanoma (conhecido como CD146), o qual está menos expresso em condições de hipóxia (57). As CTMs foram caracterizadas como osteoprogenitoras $\mathrm{CD}_{146^{+}}$e $\mathrm{CD} 45^{-}$, as quais possuem a capacidade de formar colônias fibroblásticas, além de gerar um nicho heterotópico na MO em um modelo de transplante subcutâneo (58). Outros marcadores que evidenciam a existência de subtipos de CTMs que parecem influenciar na regulação do nicho das CTHs na MO foram descritos em estudos recentes. Em camundongos, o subtipo celular $\mathrm{CD} 1^{+} \mathrm{CD} 105^{+} \mathrm{CD}^{-} 0^{-} \mathrm{CD} 45^{-}$Tie2-, isolado de osso fetal, foi infundido na cápsula do rim destes animais e essas células foram capazes de reconstituir a ossificação endocondral, ou seja, as células mesodérmicas foram capazes de se transformarem em células produtoras de cartilagem (condrócitos), antes da formação óssea e da atividade 
hematopoética (59). Já as células perivasculares da MO, PDGFR $\alpha^{+} \mathrm{Sca}^{+} \mathrm{CD}^{+} 5^{-} \mathrm{Ter}^{-1} 9^{-}$ deram origem a $\mathrm{Ob}$, células reticulares e adipócitos após o transplante em camundongos irradiados (29).

Outros estudos mostraram que as células estromais perivasculares, conhecidas como nestina ${ }^{+}$(nestina $^{+} \mathrm{CD}^{-} 1^{-} \mathrm{CD} 45^{-}$), apresentam a capacidade de formar colônias fibroblásticas e clones "spheres" (denominados "mesenspheres") quando cultivadas em condições não aderentes. Várias análises de transplantes revelaram que estas células podem se autorrenovar, além de apresentarem atividade hematopoética em ensaios de ossos heterotópicos.

\subsection{4-Células CAR (do inglês, CXCL-12 abundant reticular cells)}

As quimiocinas pertencem a uma grande família de pequenas citocinas quimioatraentes que foram identificadas pela sua capacidade de controlar a adesão, quimiotaxia e ativação leucocitária. As quimiocinas estão envolvidas em processos biológicos importantes, como a angiogênese, hematopoese, desenvolvimento embrionário dentre outros (60). A quimiocina CXCL-12 foi caracterizada como um fator de crescimento de precursor de célula B (61). Alguns estudos mostram que a sinalização entre a quimiocina CXCL-12 e seu receptor CXCR-4 é essencial para o "homing", manutenção das CTHs e desenvolvimento das células imunes, incluindo células B, células dendríticas plasmocitóides e células NK na medula óssea $(62,9)$.

Camundongos contendo a proteína CXCL-12 ligada a um promotor da proteína verde fluorescente (do inglês, green fluorescent protein-GFP) apresentaram alta expressão de CXCL-12-GFP em uma pequena população de células reticulares, denominadas células reticulares abundantes em CXCL-12. Estas células possuíam longos prolongamentos e estão distribuídas ao longo da medula óssea formando uma rede $(63,25)$. Neste trabalho, Sugiyama 2006, mostrou que a deleção de CXCL12 em camundongos adultos resultou na redução do número de CTHs e aumento na sensibilidade a dano mielotóxico, embora não impedisse a proliferação de fenótipos mais maduros. A maioria das CTHs foi encontrada em contato íntimo com as células CAR, estas por sua vez, foram encontradas circundando as células endoteliais sinusoidais ou próximas ao endósteo. A sinalização CXCL12-CXCR4 tem papel essencial na manutenção do "pool" de CTHs quiescentes, e as células CAR parecem ser um 
componente essencial dos nichos vascular e endosteal na MO adulta. Entretanto, $97 \%$ das CTHs $\left(\mathrm{CD} 150^{+} \mathrm{CD}^{-} 8^{-} \mathrm{CD} 41^{-}\right)$, precursoras de células $\mathrm{B}$, células plasmáticas, células dendríticas plasmocitóides e células NK estavam em contato com os prolongamentos das células CAR, sugerindo que as células CAR atuam no nicho não apenas na manutenção das CTHs, mas também sobre uma variedade de células imunes produzidas na MO $(24,63,64,65)$.

Sugiyama e colaboradores, (2006), utilizando análise histoquímica mostraram que todas as células endoteliais da MO estavam cercadas por células CAR (25), que não expressam marcadores pan-endoteliais, de plaquetas (PECAM-1)/CD31 ou de células do músculo liso $\alpha$-actina (SM $\alpha \mathrm{A}$, do inglês, smooth muscle $\alpha$ actin), indicando que estas células são diferentes das células endoteliais e das de músculo liso (63). A análise imunofenotípica por citometria de fluxo revelou que as células CAR não expressam CD45, Sca-1 ou CD31 e exibem expressão homogênea de molécula de adesão vascular celular-1 (VCAM-1, do inglês, vascular cell adhesion molecule), CD44, receptor do fator de crescimento derivado de plaquetas (PDGFR- $\alpha$ e PDGFR $\beta$, do inglês, platelets derived growth factor receptor), sugerindo que estas células são uma população homogênea e podem ser identificadas como células $\mathrm{CD}^{2} 5^{-} \mathrm{CD} 31^{-} \mathrm{PDGFR}^{+}(66)$.

Para avaliar a função das células CAR in vivo, Omatsu e colaboradores, 2010 utilizaram modelo murino, no qual as células CAR foram depletadas. Nestes animais as CTHs apresentavam número e tamanho reduzido, fenótipo quiescente e expressavam genes da linhagem mielóides enquanto o número de células $\mathrm{B}$ e progenitores eritróides estava diminuído. Além disso, a maioria das células CAR expressavam genes da linhagem adipogênica e osteogênica, e tinha potencial para a diferenciação de adipócitos e $\mathrm{Ob}$ (66).

Em animais CXCL-12/GFP, a expressão de CXCL12 e SCF, os quais são fatores essenciais para a proliferação de células B, progenitores eritróides e CTHs, estava elevada em células CAR quando comparadas com outras populações de células. Consistente com estes achados, a depleção de células CAR in vivo comprometeu a produção de SCF e CXCL-12 na MO (66). Na medula óssea humana, estudos apontam que células perivasculares que expressam CD146 são os progenitores estromais (58). Alguns estudos avaliaram que este subtipo de células CD146+é uma grande fração das células estromais perivasculares e também expressam PDGFR- $\alpha$, CD51 e filamento de proteína nestina. Células localizadas próximas às fibras do nervo adrenérgico apresentam a capacidade de 
formar colônias fibroblásticas, além de expressarem genes mediadores da manutenção e retenção das CTHs como, por exemplo, os que codificam a quimiocina CXCL-12 e o SCF. A caracterização dessas células indica que elas apresentam um perfil de expressão de genes e de proteínas de membrana semelhantes às células CAR presentes em camundongos $(67,68)$. Esses dados sugerem que as células progenitoras estromais CAR e CD146 ${ }^{+}$são progenitores adipo-osteogênico essenciais para a proliferação de células B, progenitores eritróides e CTHs, além de participarem da manutenção e retenção de células CTHs indiferenciadas.

\subsection{5- Células mesenquimais nestina ${ }^{+}$e leptina ${ }^{+}$}

A nestina é um filamento de proteína intermediário que foi identificado como um marcador de progenitores neurais (69). Sua expressão tem sido detectada em células progenitoras e células endoteliais (70). Mendez-Ferrer e colaboradores 2010, identificaram uma população de células mesenquimais que expressam nestina e que estão associadas às CTHs. As células mesenquimais nestina ${ }^{+}\left(\mathrm{CMN}^{+}\right)$são definidas como células estromais perivasculares que estão localizadas nas áreas centrais da MO, porém, em baixa frequência, também podem ser encontradas nas proximidades do endósteo (67).

Estudos mostraram que as $\mathrm{CMN}^{+}$que se encontram associadas às fibras do nervo adrenérgico do Sistema Nervoso Simpático (SNS), e que parecem estar envolvidas com a mobilização das CTHs, são responsáveis pelo número destas células circulantes no sangue periférico de acordo com as oscilações circadianas (30,31). Aproximadamente $1 \%$ destas células são formadoras de colônias fibroblásticas e expressam vários genes que contribuem para a manutenção das CTHs, como CXCL12, SCF e angiopoetina.

Ding e colaboradores, (2012) mostraram que o receptor de leptina também é expresso em células estromais perivasculares da MO. Similares às células $\mathrm{CAR}$, as células estromais que expressam receptores de leptina, também produzem CXCL12 e SCF, o que sugere que estas células, assim como as células CAR, estão em grande parte presentes na população de células estromais. Baseando-se nessas afirmações, os autores removeram o gene que codifica o SCF nas células leptina ${ }^{+}$e observaram uma redução no número de CTHs, indicando que estas células são importantes componentes celulares para nicho de células-tronco da medula óssea (26). 


\subsection{6- Células endoteliais}

Estruturas endoteliais dão origem as primeiras CTHs definitivas durante o desenvolvimento embrionário (71). Dados, sugerem um papel importante do endotélio da MO de indivíduos adultos na regulação de CTHs.

Um estudo onde CTHs foram purificadas e identificadas pela expressão de moléculas de ativação de sinalização linfocíticas (SLAM), tais como CD150, CD244 e CD48, mostrou que as mesmas encontravam-se localizadas preferencialmente em estruturas endoteliais $(22,73,74)$. Sabe-se que CTHs circulam e são espontaneamente mobilizadas $(73,75)$, e que a vasculatura é essencial para o tráfego de CTHs entre a medula e a circulação sanguínea. Além disso, células endoteliais secretam fatores que são fundamentais para a expansão de CTHs ex vivo, como CXCL-12, SCF e Ang-1 $(76,77,78)$. Especificamente, a heterogeneidade do microambiente da medula tem sido descrita, onde arteríolas e vasos sinusóides estão presentes, e a regeneração de células endoteliais é necessária para a recuperação da mieloablação (79). O papel de CE na proliferação de CTHs é descrito por Wikler et al, no trabalho onde demonstram que uma molécula específica de células endoteliais, a E-selectina induz a proliferação in vivo, este trabalho entretanto não demonstra qual ligante da E-selectina expresso nas CTHs seria o responsável pela indução da proliferação destas células (80). Outro estudo realizado por Ding et al, mostrou a importância das células perivasculares e endoteliais para a manutenção do nicho, relacionando a perda de CTHs com a deleção do gene do fator de células-tronco (do inglês: stem cell factor - Scf) tanto nas CE quanto nas células perivasculares que expressam leptina (28). Juntos, estes dados sugerem que as CE também contribuem para a manutenção e proliferação de CTHs no nicho.

\subsection{7 - Adipócitos}

O número de adipócitos na MO aumenta de acordo com a idade, especialmente em humanos. Naveiras e colaboradores, (2009) mostraram que a MO, rica em adipócitos, apresenta diminuição no número de CTHs quando comparada à MO pobre em tecido adiposo. Em camundongos com adipogênese comprometida, a atividade hematopoética está aumentada quando comparada aos animais com MO normal, sugerindo então que adipócitos tem um papel inibitório na manutenção das CTHs (81). 


\subsection{8 - Sistema nervoso simpático e células da glia (Schwann)}

O TGF- $\beta$ (do inglês, transforming-growth fator $-\beta$ ) é um importante regulador de CTHs, pois induz a quiescência destas células in vitro. Yamazaki e colaboradores, (2009), evidenciaram que a perda da sinalização de TGF- $\beta$ comprometeu a repopulação de CTHs na medula. As células da glia, especificamente as "nonmyelinating Schawann", parecem estar envolvidas com a regulação de CTHs no nicho, por serem as maiores produtoras de TGF- $\beta$ ativo na medula (82). O SNS está relacionado ao tráfego das CTHs da MO para a circulação sanguínea (31). Isto é regulado pelo ciclo circadiano e por sinais adrenérgicos provenientes dos nervos simpáticos presentes na MO. Células mesenquimais e progenitores nestina ${ }^{+}$estão em contato direto com nervos simpáticos e apresentam expressão aumentada de genes que promovem a manutenção das CTHs. A interação eletromecânica entre os nervos noradrenérgicos e as $\mathrm{CMN}^{+}$através do receptor adrenérgico $\beta 3$, diminui a expressão desses genes associados à manutenção da fisiologia das CTHs, tais como CXCL-12, Ang-1, KitL e a VCAM-1, o que conduz as CTHs para a circulação sanguínea $(67,30)$. Estudos demonstraram que o rompimento do nervoso simpático resultou na perda de células Schawann o que está associado à diminuição da expressão do TGF- $\beta$ ativo e a perda de CTHs $(32,82)$

\subsection{9 - Macrófagos}

Os macrófagos parecem ter papel contrário ao dos nervos simpáticos, ou seja, estão relacionados com a manutenção e a retenção das CTHs na medula óssea (83).

Camundongos tratados com G-CSF, o qual promove a mobilização das CTHs para o sangue periférico e aumento na produção de granulócitos, apresentaram depleção das células osteoblásticas e macrófagos resultando na redução da expressão gênica de CXCL12, SCF e Ang-1 nas células mesenquimais nestina ${ }^{+}(33,84)$. Portanto, a redução da população de macrófagos coincide com a redução de fatores que mantêm as células progenitoras no nicho (84). Estes resultados sugerem que os macrófagos são reguladores positivos das células do nicho, tais como as células mesenquimais nestina + , além de manter a expressão de vários fatores necessários para a manutenção das CTHs, incluindo CXCL-12. 


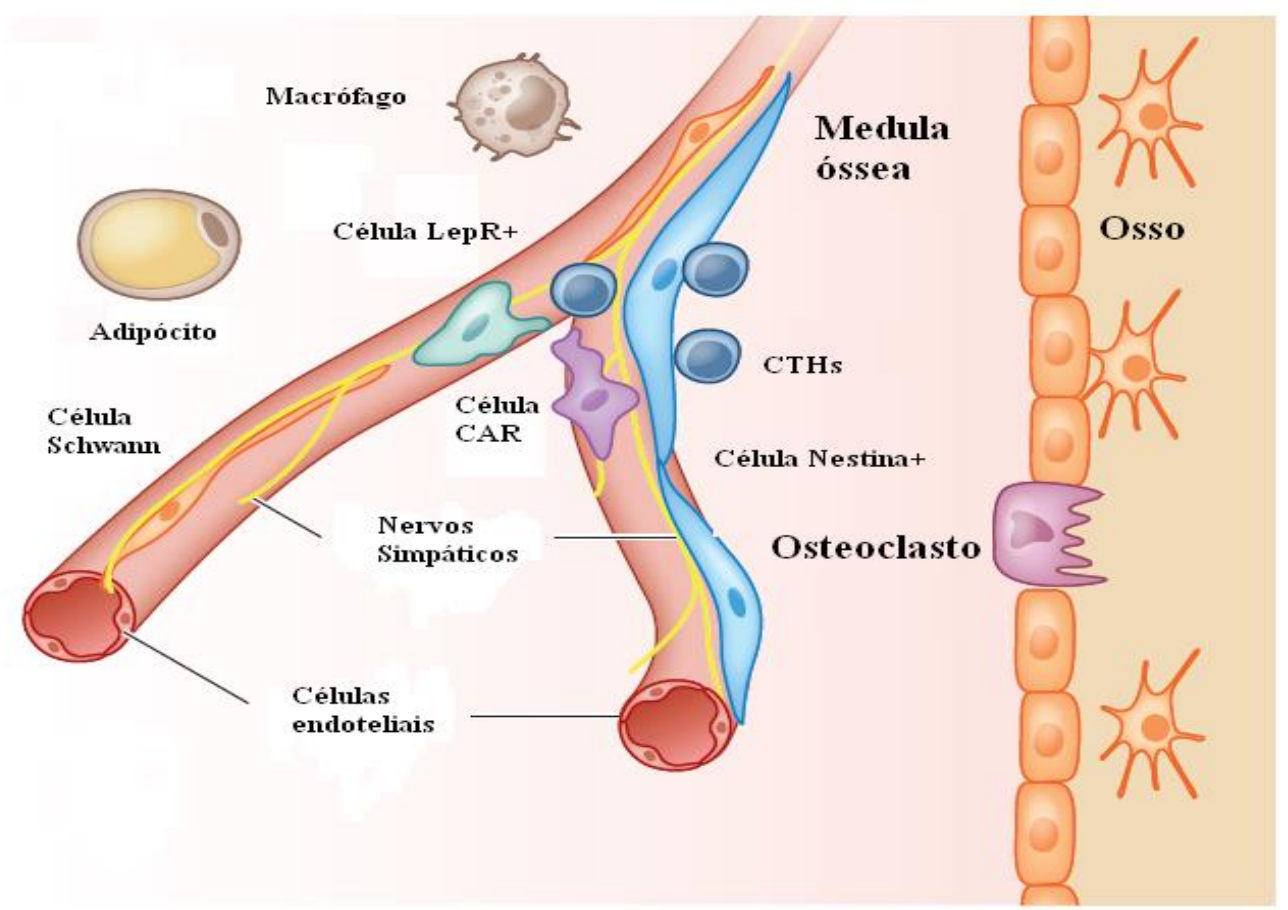

Figura 4 - Componentes celulares do nicho de células-tronco hematopoéticas. $O$ contato entre células endoteliais e células perivasculares e outros tipos de células resulta na síntese de fatores solúveis e de contato célula/célula que promove a manutenção das CTHs. Células como macrófagos, adipócitos, osteoclastos, regulam as células do nicho, contribuindo indiretamente para a manutenção da célula-tronco (adaptado de Frenette et al, 2013).

\section{6- Fatores que regulam a atividade hematopoética no nicho}

Muitas CTHs encontram-se em estado quiescente (fase G0/G1 do ciclo celular) (85). Entretanto, inúmeros estudos em modelos animais mostram que a regulação e a manutenção das CTHs são dependentes de vários fatores e sinais que ocorrem no microambiente. Além disso, vários estudos mostraram que as vias de sinalização SDF-1 (CXCL-12) /CXCR4, Mpl/Trombopoetina (TPO), Tie2/Angiopoetina, via de sinalização Notch e Wingless (Wnt) influenciam e regulam o nicho das CTHs. A seguir comentamos a função de algumas moléculas e receptores no nicho.

\subsection{1- SDF-1/CXCR-4}

A SDF-1 (CXCL-12) é uma quimiocina expressa em vários órgãos como pulmão, fígado e medula óssea (86). Pertence ao grupo das quimiocinas- $\alpha$ cuja função é atrair os progenitores primitivos e comprometidos, regular o desenvolvimento embrionário e manter a homeostase (86). O CXCR-4 (CD184) é um receptor de superfície, expresso em 
CTHs e em outros tipos de células como os linfócitos. A estimulação com citocinas como o SCF, IL6 ou HGF (do inglês, hepatocyte growth factor) leva a super expressão do CXCR-4 em células CD34+ humanas num período de 24 a 48 horas, o que resulta a ligação da SDF-1/ CXCR4 mediando a migração e a repopulação in vivo $(87,88,89)$. Esta via tem um papel importante durante o desenvolvimento embrionário na regulação da linfopoese de células $\mathrm{B}$, da mielopoese na medula óssea e na formação do septo ventricular do coração $(90,91)$. Além de ser bem conhecida por participar de processos fisiológicos importantes como a migração (homing), retenção (lodgement) e da repopulação (engraftment) de CTHs $(92,93)$.

O homing é um processo rápido (pode levar horas e não mais que 1 a 2 dias) onde as CTHs atravessam a barreira do endotélio arterial e se alojam nos compartimentos da MO. É um processo coordenado por múltiplos passos, que acontece pelo rolamento das células-tronco e progenitores, adesão destes nas células endoteliais de pequenos vasos sanguíneos e a migração é realizada através do endotélio e da matriz extracelular. Após este processo, acontece o alojamento de CTHs em nichos especializados por um processo seletivo de ancoragem, ou lodgement. (94). Vários tipos celulares, incluindo as CTHs de longo termo CD34+CD38-, e progenitores CD34+CD38+, maduros e neutrófilos podem migrar para a MO, mas somente CTHs migram para o nicho endosteal para iniciar a repopulação de longo-termo (95).

Na medula óssea, as CTHs podem se associar aos osteoblastos no nicho endosteal ou a células endoteliais do nicho vascular. A SDF-1 é expressa por osteoblastos imaturos na região do endósteo (96), por isso estudos indicam que CTHs migram preferencialmente para perto da superfície do endósteo. Apenas uma pequena fração, permanece em contato com a interface óssea. O posicionamento das CTHs no nicho ainda é bastante discutido, acreditase que devido um processo randômico as CTHs ficam no primeiro nicho que encontram, ou então isso depende do status de cada célula como, por exemplo, estágio do ciclo celular e diferenciação $(97,98,99)$.

A expressão do SDF-1/CXCR4 é regulada pelo fator regulador de hipóxia-1 (HIF1), e uma vez que a MO encontra-se parcialmente em hipóxia (100), ambos são expressos por vários tipos de células incluindo células hematopoéticas maduras e imaturas, células estromais que revestem a região do endósteo e progenitores mesenquimais $(96,101)$. 
Estudos realizados através da inativação e/ou deleção do receptor CXCR-4 em camundongos resultaram na redução das células CTHs quiescentes levando à proliferação exacerbada destas $(26,90)$. Tzheng e colaboradores, (2011) confirmaram o papel da quimiocina SDF-1 na manutenção das CTHs, uma vez que camundongos deficientes apresentaram diminuição na população de CTHs quiescentes no nicho endosteal (102).

\subsection{2- c-Mpl/TPO}

O receptor c-Mpl e seu ligante, a trombopoetina (TPO), são conhecidos por regularem a megacariopoese (103). A TPO é um hormônio glicoprotéico produzido pelo fígado e rins enquanto que seu receptor c-Mpl é expresso principalmente nas CTHs, e menos expressos em progenitores megacariocíticos, megacariócitos e plaquetas (104). A hematopoese é mediada por tecidos que expressam o receptor c-Mpl como a MO, baço e o fígado fetal (105). Alguns estudos mostram que esta via está relacionada à manutenção das CTHs em estado quiescente e à progressão do ciclo celular na superfície endosteal $(106,43)$. A expressão de c-Mpl nas CTHs foi correlacionada à quiescência por estar intimamente associada com a TPO produzida pelas células osteobláticas presentes na medula óssea (106). Um estudo recente realizado em camundongos TPO knock-in $\left(\mathrm{RAG}^{-{ }^{-}} \mathrm{\gamma c}^{-/-}\right)$, onde células progenitoras hematopoéticas humanas foram transplantadas, mostrou melhora no enxerto e na manutenção destas células na medula óssea. Portanto, este estudo sugere que a TPO é importante para a manutenção e autorrenovação das CTHs.

\subsection{3- Tie2/Ang-1}

A Ang-1 é o ligante de Tie-2 que é o receptor tirosina quinase, expresso predominantemente em células osteobásticas presentes no endósteo (42) e em CTHs (58). A interação Tie2/Ang-1 resulta na adesão de CTHs ao nicho, o que as torna ainda mais quiescentes (42).

\subsection{4- Via de sinalização Notch}

A via de sinalização Notch pode ser dividida em dois tipos: canônica e nãocanônica. A via canônica é bem conhecida pelo seu papel no desenvolvimento e no destino celular, enquanto estudos recentes mostram que a via não canônica é importante para vários processos celulares, aos quais podemos incluir a oncogênese e a ativação de 
linfócitos T (107). A contribuição da via Notch canônica na manutenção das CTHs no nicho ainda é bastante discutida $(108,109,110)$. Em humanos, a via Notch foi descoberta há 23 anos como uma oncogene que após a translocação cromossomal, era responsável pelo desencadeamento da Leucemia (111). Desde então, vários estudos foram realizados para demonstrar o papel desta via na diferenciação de linfócitos T $(112,113)$. Logo foi sugerido que a via Notch poderia ter papel na biologia das CTHs primitivas, bem como no microambiente que expressa tanto Notch quanto seus receptores $(113,114)$. Vários grupos têm desmosntrado que os ligantes da família Notch como o Jagged e o Delta podem estar relacionados com a expansão de progenitores hematopoéticos humano e murino in vitro $(115,116)$. É importante enfatizar, que a ativação desta via ocasiona aumento na autorrenovação e na capacidade de repopulação a longo termo de CTHs in vivo. (117) Quando Calvi e colaboradores (2003), descreveram que os osteoblastos faziam parte da regulação do nicho, eles mostraram que o receptor do hormônio da paratireóide ativado nestas células estimulava a expressão de Jagged-1. Uma vez ativados os osteoblastos foram capazes de aumentar a autorrenovação de CTHs primitivas. Além disso, células LSK (Lin-Sca1+Kit-) de camundongos transgênicos tinham níveis de Notch intracelular aumentados e o elevado número de CTHs primitivas poderia ser normalizado com um inibidor. Apoiando estes dados, Duncan e colaboradores (2005) observaram que o gene Notch estava ativo em células hematopoéticas c-kit no osso trabecular (38). Estes resultados indicam que não somente os osteoblastos são parte do nicho de CTHs, mas que a via de sinalização Jagged/Notch ativada por estas células podem ser importantes na regulação da autorrenovação de CTHs (118).

\subsection{5- Wnt}

A primeira evidência do envolvimento da sinalização Wnt nas funções das CTHs vem de um estudo que mostrou que os ligantes da Wnt e os receptores são produzidos não apenas pelos progenitores, mas também pelas células que constituem o microambiente circundante, tanto em camundongos como em humanos. Este padrão de expressão indica tanto efeitos autócrinos como parácrinos dos ligantes de Wnt.

Existem pelo menos três vias de sinalização Wnt, sendo que uma é a via canônica dependente de $\beta$-catenina, outra é a via conhecida como "planar cell polarity" (PCP) e a via de cálcio (Wnt-Ca+ ${ }^{+}$(119). A via canônica tem sido muito estudada em células do sistema imunológico e do sangue, onde a $\beta$-catenina é o principal alvo. A proteína $\beta$ - 
catenina está localizada no citoplasma e tem um papel importante nas junções aderentes celulares. Possui vida curta, devido à atividade do complexo de destruição multiprotéico (120).

$\mathrm{Na}$ ausência da proteína Wnt que se liga ao complexo de receptores, composto pelo receptor Frizzled (FZ) e co-receptor de baixa densidade proteica (LRP5 ou LRP6), a $\beta$-catenina é fosforilada e degradada no proteassoma através do complexo de destruição, levando a sua ubiquitinização e a degradação proteassomal. No núcleo, devido à ausência da $\beta$-catenina, o fator de transcrição TCF/LEF silencia os genes alvos da Wnt (120).

$\mathrm{Na}$ membrana da célula, a proteína Wnt se liga ao receptor Frizzeld e aos coreceptores LRP5 ou LRP6 para ativar a cascata de sinalização (Figura 5b). Após a ligação da Wnt ao receptor, ocorre a fosforilação dos co-receptores. O acúmulo de $\beta$-catenina, provavelmente na sua forma desfosforilada, leva a sua translocação para o núcleo. A formação do complexo $\beta$-catenina-TCF/LEF, promove a ativação de genes alvos da Wnt (120).

Estudos demonstram que as CTMs residem na MO e são consideradas parte do nicho das CTHs, porém poucos estudos mostram o quanto o envelhecimento destas células pode impactar nos aspectos fenotípicos e funcionais das CTHs, uma vez que a habilidade de dar suporte e manutenção às CTHs já é bem conhecida. Assim sendo, é relevante a investigação da influência das CTMs de doadores de diferentes idades na manutenção de CTHs, bem como sua relação com as vias envolvidas na manutenção do estado indiferenciados destas células. 


\section{1- HIPÓSTESE}

Nossa hipótese é de que as células-tronco mesenquimais (estromais) são células importantes na manutenção da homeostase do nicho medular, e que o envelhecimento destas células pode afetar o processo de autorrenovação, multipotência e diferenciação das células-tronco hematopoéticas.

\section{2- RELEVÂNCIA}

O estudo da interação de células-tronco hematopoéticas e células-tronco mesenquimais de diferentes idades visa elucidar o papel das CTMs na hematopoese durante o envelhecimento, trazendo novo conhecimento para a sociedade científica e esclarecimento sobre a importância das CTMs na manutenção da homeostase do nicho das CTHs.

\section{3- OBJETIVOS}

\section{1- Gerais}

Avaliar a influência das células-tronco mesenquimais derivadas da medula óssea de doadores de diferentes idades na manutenção do estado de multipotência, autorrenovação e diferenciação de células-tronco hematopoéticas.

\section{2- Específicos}

- Avaliar o perfil imunofenotípico de CTHs após o co-cultivo com as CTMs de diferentes idades.

- Avaliar a funcionalidade de CTHs e progenitores hematopoéticos por ensaio clonogênico.

- Quantificar a secreção da quimiocina CXCL-12 (SDF-1) no sobrenadante

do co-cultivo de CTHs com as CTMs de diferentes idades. 


\section{5- MATERIAIS E MÉTODOS}

\section{1- Casuística}

As amostras foram coletadas a partir de procedimentos cirúrgicos seguido pelo isolamento e a caracterização das células utilizadas no estudo.

As células utilizadas no presente estudo estão descritas na Tabela 1 e foram obtidas a partir de 22 bolsas de sangue de cordão umbilical (SCU) e 27 filtros descartáveis dos quais foram isoladas as CTMs de doadores de medula óssea de idades variadas.

\begin{tabular}{|l|l|l|}
\hline SCU & CTMs & Idades \\
\hline SCU 5 & Hmo 11 & 12 \\
\hline SCU 7 & Hmo 12 & 75 \\
\hline SCU 10 & Hmo 15 & 7 \\
\hline SCU 11 & Hmo 20 & 6 \\
\hline SCU 12 & Hmo 25 & 47 \\
\hline SCU 15 & Hmo 26 & 25 \\
\hline SCU 16 & Hmo 27 & 20 \\
\hline SCU 17 & Hmo 28 & 30 \\
\hline SCU 18 & Hmo 29 & 46 \\
\hline & Hmo 31 & 4 \\
\hline & Hmo 33 & 20 \\
\hline & Hmo 34 & 48 \\
\hline & Hmo 35 & 22 \\
\hline & Hmo 37 & 22 \\
\hline & Hmo 38 & 49 \\
\hline & Hmo 39 40 & 35 \\
\hline & Hmo 42 & 49 \\
\hline & & 65 \\
\hline Total de amostras & 18 \\
\hline 9 & &
\end{tabular}

Tabela 1 - Casuística - SCU e CTMs de diferentes idades utilizados neste estudo.

\section{2 - Obtenção, cultivo e manutenção das células-tronco mesenquimais}

As células-tronco mesenquimais foram obtidas de filtro de coleta de medula óssea descartável e são provenientes de doadores saudáveis de idades variadas. As amostras foram coletadas após a aprovação deste projeto pelos comitês de ética em pesquisa do Hospital Israelita Albert Einstein e da Faculdade de Medicina de São Paulo - FMUSP (Anexo I), registrado na Plataforma Brasil sob o CAAE número: 21840113.0.0000.0071. 
Os filtros foram lavados com meio de cultura Dubelco Modificado (DMEM) (Gibco, Carlsbad, CA) suplementado com 10\% soro fetal bovino (SFB), 1\% antibióticoantimicótico (1000 unidades $/ \mathrm{mL}$ penicilina, $1000 \mu \mathrm{g} / \mathrm{mL}$ estreptomicina e $25 \mu \mathrm{g} / \mathrm{mL}$ Fungizon) e 1\% L-glutamina (Gibco, Carlsbad, CA). Este meio de cultura suplementado será denominado no decorrer desse trabalho como Mc1.

Após a lavagem do filtro de coleta, o conteúdo obtido foi separado por gradiente de densidade Ficoll-Paque (GE Healthcare, United Kingdom) com densidade de 1.077 na proporção de $3 \mathrm{~mL}$ de ficoll para cada $4 \mathrm{~mL}$ de amostra, e centrifugado a $500 \mathrm{~g}$, por 30 minutos, a $22^{\circ} \mathrm{C}$, para a obtenção da fração de células linfomononucleares (LMN).

Em seguida, a fração LMN, separada e diluída em Mc1, foi centrifugada novamente a $500 \mathrm{~g}$ por 10 minutos, a $22^{\circ} \mathrm{C}$. Aproximadamente $1 \times 10^{6} / \mathrm{mL}$ células foram ressuspendidas em $5 \mathrm{~mL}$ de $\mathrm{Mc} 1$, semeadas em frascos de cultura de $25 \mathrm{~cm}^{2}$ e armazenados em estufa a $37^{\circ} \mathrm{C}$ e $5 \%$ de $\mathrm{CO}_{2}$.

Após 48 horas de incubação foi realizada a primeira troca do meio de cultura. $\mathrm{O}$ sobrenadante contendo células que não aderiram à superfície plástica dos frascos de cultura foi desprezado.

As células aderidas ao plástico foram consideradas na passagem zero (P.0). Após atingirem cerca de $80 \%$ a $90 \%$ de confluência, as células foram passadas a novas garrafas, ou seja, o sobrenadante foi removido, em seguida as células aderidas foram lavadas duas vezes com tampão fosfato sem cálcio e magnésio (DPBS) (Gibco,Carlsbad,CA) e $1 \mathrm{~mL}$ de tripsina (TrypLE ${ }^{\mathrm{TM}}$ express - Gibco, Carlsbad, CA) foi adicionado. Em seguida, as células foram incubadas por 5 minutos em estufa a $37^{\circ} \mathrm{C}$ e $5 \%$ de $\mathrm{CO}_{2}$ ocasionando o desprendimento das mesmas. Para inativar a ação da tripsina, todo o conteúdo foi ressuspendido em $4 \mathrm{~mL}$ de $\mathrm{Mc} 1$ e transferido para um tubo cônico de $15 \mathrm{~mL}$. Em seguida as amostras foram centrifugadas a $500 \mathrm{~g}$, por 10 minutos, a $22^{\circ} \mathrm{C}$ e semeadas na proporção de 1:3. A cada plaqueamento as células avançavam uma passagem, seguindo para P.1, P.2 e assim sucessivamente. Ao longo do cultivo celular o meio foi trocado em dias alternados. Todas as células foram testadas para contaminação aeróbia, anaeróbia e para Mycoplasma sp. 


\section{3- Caracterização Imunofenotípica das CTMs por citometria de fluxo}

As CTMs foram removidas dos frascos de cultura na $4^{\mathrm{a}}$ passagem e centrifugadas $500 \mathrm{~g}, 5$ minutos, a $22^{\circ} \mathrm{C}$. Em seguida, o sobrenadante foi descartado, as células foram homogeneizadas e ressuspendidas em $1 \mathrm{~mL}$ de tampão de lavagem para citometria $(\mathrm{C} 1)$ que é composto por tampão fosfato sem cálcio e sem magnésio DPBS, 1\% de albumina humana (Grifols, Barcelona, Espanha) e 0,1\% de azida sódica (Sigma, St Louis,MO).

As células foram marcadas com anticorpos monoclonais, CD106-FITC (clone: 51-10C9), CD73-PE (clone:AD2), CD34-PE (clone: My10), CD105-PE-CF594 (clone: 266) CD90-PE-Cy7 (clone: SE10), CD29-APC (clone: MAR04), CD14-Alexa 700 (clone: M5E2), CD45-V500 (clone:H130) e CD31-V450 (clone: WM59) BD Pharmingen (San Diego - CA), CD44-PerCPCy5 (clone: G44-26), HLA-DR-APC-H7 (clone:G46-6) BD Biosciences (San Jose - CA) e o controle realizado por FMO (do inglês Fluorescence minus one).

Para a marcação, as células foram incubadas por 30 minutos com os anticorpos, na ausência de luz a temperatura ambiente. Posteriormente, o material foi lavado com PBS e centrifugado a $500 \mathrm{~g}$ por 5 minutos, a $22^{\circ} \mathrm{C}$ e ressuspendido em $200 \mu 1$ da solução C1. A aquisição das amostras foi realizada no citometro de fluxo FACS ARIA e foram adquiridos pelo menos 10.000 eventos por tubo.

A análise foi realizada utilizando o software BD FACSDiva 6.1.3 (BD Biosciences, San Jose,CA) ou FLOWJO (TreeStar, Ashland, OR).

\section{4-Diferenciação das células-tronco-mesenquimais}

As CTMs foram diferenciadas nas seguintes linhagens celulares: adipogênica, osteoblástica e condrogênica utilizando os protocolos descritos abaixo. Para todas as diferenciações, as CTMs foram plaqueadas na $4^{\text {a }}$ passagem em placa de cultura de 6 poços. Ao atingirem a confluência de aproximadamente $80 \%$, o meio de cultura Mc1 foi substituído por um meio de cultura específico para induzir a diferenciação de cada uma das diferentes linhagens. 


\subsection{1-Protocolo de diferenciação adipogênica}

Para a diferenciação em adipócitos, o meio de cultura Mc1 foi substituído pelo meio de diferenciação adipogênica composto por alpha-MEM (Gibco, Carlsbad, CA) e suplementado com $10 \%$ de SFB, $1 \%$ de antibiótico-antimicótico, $1 \mu \mathrm{M}$ dexametasona (Sigma, St Louis, MO), 100 $\mu \mathrm{g} / \mathrm{ml}$ de isobutil-metil-xantina (IBMX -Sigma, St Louis, MO) $10 \mu \mathrm{g} / \mathrm{ml}$ de insulina (Sigma, St Louis, MO) e 100 $\mu \mathrm{M}$ de indometacina (IDT - Sigma, St Louis, MO). O meio de diferenciação adipogênica foi adicionado à cultura e trocado em dias alternados durante 21 dias. Após esse período, a diferenciação foi evidenciada por coloração imuno-histoquímica com o corante oil-red.

\subsection{2-Protocolo de diferenciação osteogênica}

Para a diferenciação em osteoblastos, o meio de cultura Mc1 foi substituído pelo meio de diferenciação osteogênica composto por alpha-MEM e suplementado com $10 \%$ de SFB, $1 \%$ de antibiótico-antimicótico, $1 \mu \mathrm{M}$ dexametasona (Sigma, St Louis, MO),

$2 \mu \mathrm{g} / \mathrm{ml}$ de ácido ascórbico (Sigma, St Louis, MO) e $10 \mu \mathrm{M}$ de beta-glycerol-fosfato (Sigma, St Louis, MO). O meio de diferenciação osteogênica foi adicionado à cultura e trocado em dias alternados durante 21 dias. Após esse período a diferenciação foi evidenciada por coloração imuno-histoquímica com o corante alizarin-red.

\subsection{3- Protocolo de diferenciação condrogênica}

Para a diferenciação em condrócitos, o meio de cultura Mc1 foi substituído pelo meio de diferenciação condrogênica composto por alpha-MEM e suplementado com $10 \%$ de SFB, $1 \mu \mathrm{g} / \mathrm{ml}$ de ácido ascórbico e $10 \mathrm{ng} / \mathrm{ml}$ de TGF- $\beta$ (Sigma, St Louis, MO). O meio de diferenciação condrogênica foi adicionado à cultura e trocado em dias alternados durante 21 dias. Após esse período, a diferenciação foi evidenciada por coloração imunohistoquímica com o corante toluidine blue. 


\title{
5.5-Métodos de coloração citoquímica
}

\section{Oil-Red}

Após o cultivo por 21 dias, as células foram fixadas com $4 \%$ paraformaldeído (Sigma, St Louis, MO) por 30 minutos, lavadas com DPBS e desidratadas com 60\% isopropanol por 2-5 minutos. As células foram incubadas por 15 minutos com a solução 0,5\% Oil Red (Sigma, St Louis, MO) diluída em isopropanol. Em seguida, toda a solução foi removida e as células coradas foram lavadas 4 vezes com água deionizada. A diferenciação adipogênica foi evidenciada pela coloração com Oil Red, a qual cora as gotas lipídicas formadas no interior da célula em vermelho e na sequência foram analisadas e registradas por microscopia óptica.

\begin{abstract}
Alizarin Red
Logo após os 21 dias de diferenciação, as células foram lavadas com DPBS e fixadas com $4 \%$ paraformaldeído por 30 minutos e lavadas com água destilada. Em seguida, as células foram incubadas por 1 hora com o corante $1 \%$ Alizarin Red (2g Alizarin Red diluídos em 100 ml de água destilada, pH 4.2) (Sigma, St Louis, MO), após esse período, a solução foi removida e cada poço foi lavado duas vezes com água destilada. A diferenciação osteogênica foi evidenciada pela coloração Alizarin Red, a qual cora os depósitos de cálcio em vermelho e na sequência foram analisadas e registradas por microscopia óptica.
\end{abstract}

\section{Toluidin Blue}

Após os 21 dias de diferenciação, os poços foram lavados e as células fixadas com a seguinte sequência: $70 \%$ etanol, $90 \%$ etanol e etanol absoluto, por 1 minuto cada lavagem. As células foram incubadas por 10-15 minutos com o corante azul de toluidina (1g toluidin-blue, $1 \mathrm{~g}$ de borato de sódio diluídos em $100 \mathrm{ml}$ de água destilada) (Sigma, St Louis, MO). A diferenciação condrogênica foi evidenciada pela coloração Toluidene Blue no qual cora a matriz rica em proteoglicanos em azul e na sequência foi analisada e registrada por microscopia óptica. 


\section{6-Obtenção de células linfomononucleares do sangue de cordão umbilical}

As células linfomononucleares foram isoladas de bolsas de sangue de cordão umbilical coletados no Centro Obstétrico do Hospital Israelita Albert Einstein e do Hospital Municipal M. Boi Mirim Dr. Moysés Deutsch, mediante a assinatura do termo de consentimento livre e esclarecido (TCLE).

As amostras foram obtidas após a aprovação do projeto que originou este trabalho pelos comitês de ética em pesquisa do Hospital Israelita Albert Einstein e da Faculdade de Medicina de São Paulo - FMUSP (Anexo I), registrado na Plataforma Brasil sob o CAAE número: 21840113.0.0000.0071.

O sangue de cordão umbilical é uma fonte rica de células-tronco hematopoéticas. Geralmente as bolsas de sangue são doadas ao banco de sangue de cordão umbilical para futura reconstituição de linhagem hematopoética de pacientes com doenças hematológicas. Existem alguns critérios de qualidade (número e volume das células obtidas) que determinam o armazenamento ou o descarte dessas bolsas doadas. Assim sendo, as bolsas descartadas foram utilizadas para a realização desta pesquisa.

Para obter a fração de células LMN do sangue do cordão umbilical foi realizada a separação de células por gradiente de densidade Ficoll Paque com densidade de 1.077 centrifugados a $500 \mathrm{~g}$, por 30 minutos, a $22^{\circ} \mathrm{C}$.

As células LMN foram coletadas e congeladas em 10 tubos de criopreservação em um meio de congelamento composto por meio de cultura DMEM suplementado com $10 \%$ de SFB, $1 \%$ antibiótico-antimicótico (1000 unidades/ml penicilina, 1000 $\mu \mathrm{g} / \mathrm{ml}$ de estreptomicina, $25 \mu \mathrm{g} / \mathrm{ml}$ de Fungizon), $1 \%$ de L-glutamina (200mM) e $10 \%$ Dimetilsulfóxido (DMSO) (Baxter,Galway,Irlanda). Este meio de cultura suplementado será referenciado nesse trabalho como Mc2.

\section{7- Obtenção células- tronco hematopoéticas}

As células LMN de sangue de cordão umbilical foram descongeladas em uma solução de descongelamento composto por meio de cultura DMEM suplementado com 40\% SFB, 10U de DNase (Invitrogen, Carlsbad, CA), 1\% antibiótico-antimicótico (1000 unidades $/ \mathrm{ml}$ penicilina, $1000 \mu \mathrm{g} / \mathrm{ml}$ estreptomicina, $25 \mu \mathrm{g} / \mathrm{ml}$ de Fungizon) e $1 \%$ L- 
glutamina $(200 \mathrm{mM})$. Este meio de cultura suplementado será referenciado nesse trabalho como Mc3.

Foi realizada a contagem e a análise da viabilidade das células por câmera de Neubauer utilizando o Azul de Tripan (do inglês, Trypan Blue). Em seguida, as células foram centrifugadas $500 \mathrm{~g}$ por 5 minutos, a $22^{\circ} \mathrm{C}$ ressuspensas em $5 \mathrm{ml}$ de meio Mc1. Logo após, realizada a separação de células vivas e mortas por gradiente de densidade FicollPaque na densidade de 1.077 e centrifugado a $500 \mathrm{~g}$ por 30 minutos, a $22^{\circ} \mathrm{C}$.

A fração contendo as células vivas foi coletada, lavada com DPBS e centrifugada a $500 \mathrm{~g}$ por 5 minutos, a $22^{\circ} \mathrm{C}$. Para eliminar possíveis grumos de células, as mesmas foram filtradas em um filtro com o poro de $30 \mu \mathrm{m}$ (Macs Miltenyi Biotec, Bergisch Gladbach, Germany) e foi realizada a contagem de células com Azul de Tripan para avaliar a quantidade e viabilidade dessas células.

Em seguida as células foram ressuspensas em 500 $\mu 1$ tampão, o qual era composto por DPBS ( $\mathrm{pH} 7,2), 0,5 \%$ albumina humana e $2 \mathrm{mM}$ EDTA (S1), e foram centrifugadas a $300 \mathrm{~g}$, por 10 minutos, a $22^{\circ} \mathrm{C}$. O sobrenadante foi descartado e as células foram ressuspensas em $300 \mu 1$ de $S 1$.

As células CD34 foram separadas de acordo com o protocolo de separação CD34 Microbead Kit Human. O procedimento de marcação por microbeads foi realizado da seguinte maneira: quando o número de células foi de até $10^{8}$, as células foram marcadas

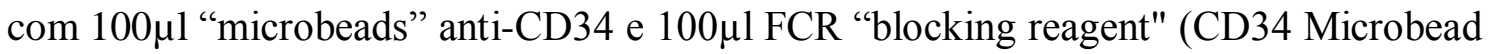
Kit human, Macs Miltenyi Biotec, Bergisch Gladbach, Germany) e quando o número de células foi inferior a $10^{8}$, utilizamos uma quantidade de beads proporcional. Estas foram incubadas por 30 minutos a $4^{\circ} \mathrm{C}$. Posteriormente, as células foram lavadas com $5 \mathrm{ml}$ do tampão S1, centrifugadas a $300 \mathrm{~g}$, por 10 minutos, a $22^{\circ} \mathrm{C}$. O sobrenadante foi descartado, o precipitado de células foi ressuspenso em $500 \mu 1$ de S1 e o procedimento de separação por cromatografia de afinidade foi realizado.

A separação das células $\mathrm{CD} 34^{+}$consiste na passagem destas células marcadas por um sistema de coluna acoplada a um magneto (Figura 5C). A coluna é lavada com o

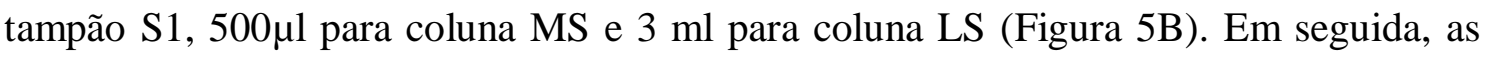
células foram adicionadas à coluna e após a passagem, é realizada a lavagem das mesmas com os volumes adequados de tampão S1. As células de interesse ficam retidas na coluna, a qual é destacada do magneto e com o auxílio da pressão de um embolo, as células de interesse são coletadas em um tubo novo. Após a separação por microbeads, o número de 
células e a viabilidade são determinados pela contagem em câmara de Neubauer utilizando Azul de Tripan (do inglês, Trypan Blue).
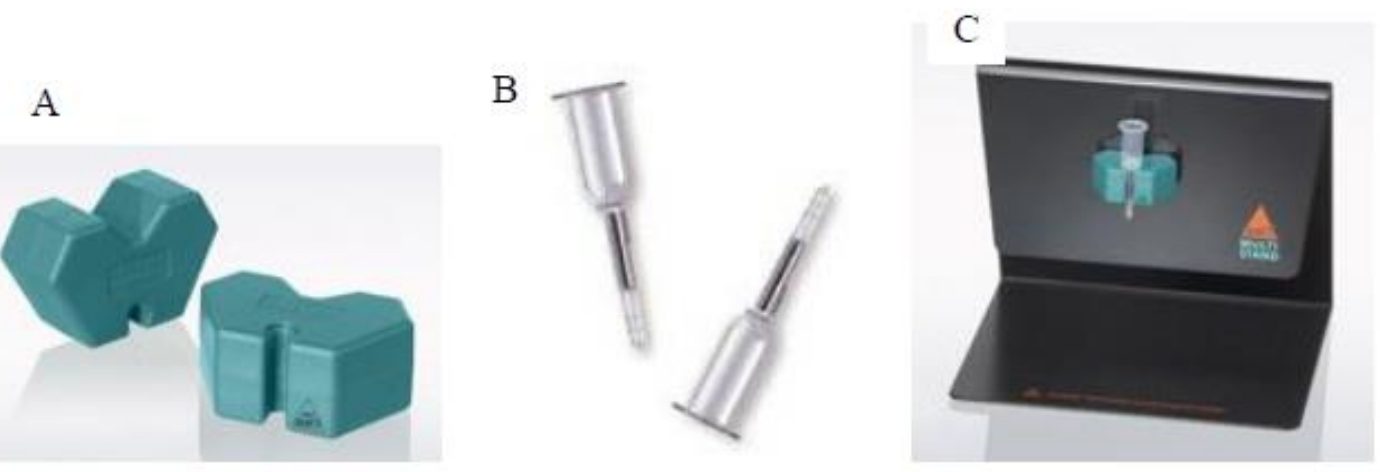

Figura 5: Separador de células miniMACS (Miltenyi Biotec), utilizado na separação de células CD34 ${ }^{+}$ (Fonte:http://www.miltenyibiotec.com)

\section{8-Caracterização imunofenotípica de células-tronco hematopoéticas}

Após a separação das células-tronco hematopoéticas (CTHs) por cromatografia de afinidade, as células foram caracterizadas por citometria de fluxo. De maneira geral, uma amostra contendo aproximadamente $4 \times 10^{5}$ células foram separadas e cerca de $3 \times 10^{5}$ células foram utilizadas para o controle isotípico, ensaio de morte celular e para a caracterização imunofenotípica. Em seguida as células foram marcadas com anticorpos monoclonais de interesse, incubadas à temperatura ambiente protegidas da luz por 30 minutos. Após esse período, as células foram lavadas com o tampão C1, centrifugadas a $500 \mathrm{~g}$, por 5 minutos, a $22^{\circ} \mathrm{C}$, ressuspendidas em $100 \mu 1$ de solução tampão $\mathrm{C} 1$ e adquiridas por citometria de fluxo.

A quantificação de células $\mathrm{CD} 34^{+}$por citometria de fluxo foi baseado no protocolo recomendado pela ISHAGE (do inglês, International Society for Hematotherapy and Graft Engineering). Além da avaliação do tamanho e complexidade celular, o protocolo permite a seleção da subpopulação de células $\mathrm{CD} 34^{+}$a partir da população total de leucócitos, marcados como anticorpo monoclonal anti-CD45 (células CD45 ${ }^{+}$).

Os anticorpos monoclonais utilizados foram: Lin- FITC, CD34-PE-Cy7 (clone: 8G12) e CD117-APC (clone: 104D2) (BD Pharmingen, San Diego, CA), CD38-PE (clone: T16) e CD45 PerCP-Cy5.5 (clone: J33) (Beckman Coulter, Marseille, France). A aquisição das amostras foi realizada no citometro de fluxo FACS ARIA e foram adquiridos pelo menos 10.000 eventos por tubo. 
Para esta análise foram utilizados os softwares FACSDIVA (BD Biosciences, San Jose, CA) e FLOWJO (TreeStar, Ashland, OR).

\section{9-Co-cultivo de células tronco-mesenquimais e células-tronco hematopoéticas}

As CTHs selecionadas por cromatografia de afinidade co-cultivadas com CTMs de diferentes idades. Em uma placa de 24 poços, as CTMs foram plaqueadas na densidade de $2 \times 10^{4}$ com o meio de cultura Mc1 e foram cultivadas a $37^{\circ} \mathrm{C}$ com $5 \%$ de $\mathrm{CO}_{2}$ em incubadora umidificada até atingirem 70\% de confluência. Em seguida, as CTHs foram semeadas na densidade de $1 \times 10^{4}$ por poço com o meio de cultura StemSpan H3000 (Stem Cell Technologies, Vancouver,Canada) suplementado com $5 \mathrm{ng} / \mathrm{ml}$ de fator de célula tronco (do inglês stem cell factor-SCF), $5 \mathrm{ng} / \mathrm{ml}$ de interleucina 6 (do inglês, interleukin 6), $5 \mathrm{ng} / \mathrm{ml}$ de Interleucina-3 (IL-3) e 6,2ng/ml de ligante da tirosina quinase-3 (do inglês, tyrosina kinase -3 ligand - Flt3-L) (R\&D Systems, Minneapolis, MN). Este meio de cultura suplementado será denominado Mc3 no decorrer deste trabalho.

As CTHs foram coletadas nos $3^{\circ}$ e $7^{\circ}$ dia para realização da análise imunofenotípica por citometria de fluxo.

\subsection{0-Coleta das duas frações de células tronco-hematopoéticas}

No $3^{\circ}$ e $7^{\circ}$ dia de co-cultivo o sobrenadante foi coletado juntamente com as CTHs que estavam em suspensão no meio de cultura (fração $S$ ). As mesmas foram centrifugadas a $500 \mathrm{~g}$, por 5 minutos, a $22^{\circ} \mathrm{C}$ e ressuspensas em $500 \mu 1$ de meio $\mathrm{Mc} 1$. Ao observar no microscópio que ainda haviam células aderidas na superfície das CTMs, foi adicionado em cada poço $1 \mathrm{~mL}$ de tripsina e incubado por 10 minutos a $37^{\circ} \mathrm{C} \operatorname{com} 5 \%$ de $\mathrm{CO}_{2}$ para o desprendimento das CTMs e CTHs aderidas à superfície das CTMs (fração A).

Em seguida, o meio Mc1 foi adicionado, as células foram coletadas e passadas para um tubo cônico de $15 \mathrm{ml}$, centrifugadas $500 \mathrm{~g}$ por 5 minutos, a $22^{\circ} \mathrm{C}$ e ressuspensas em $80 \mu 1$ de tampão S1 para realizar a separação das CTHs por cromatografia de afinidade.

Depois de ressuspensas, as células foram marcadas com 20 $\mu 1$ de CD45 Microbead Kit Human (Macs Milteny Biotec, Bergisch Gladbach, Germany) e incubadas por 15 minutos a $4^{\circ} \mathrm{C}$. Posteriormente, as células foram lavadas com $1 \mathrm{ml}$ do tampão $\mathrm{S} 1 \mathrm{e}$ centrifugadas $300 \mathrm{~g}$, por 10 minutos, a $22^{\circ} \mathrm{C}$. O sobrenadante foi descartado e o 
precipitado de células foi ressuspendido em $500 \mu 1$ de S1. Posteriormente, o procedimento de separação por cromatografia de afinidade foi realizado. Após a separação, as células foram caracterizadas por citometria de fluxo.

\subsection{1-Ensaio de Morte Celular}

Para o ensaio de morte celular, as células foram marcadas com o anticorpo monoclonal CD45- APC (clone: J33) (Beckman Coulter, Marseille, France), Anexina VFITC e Iodeto de propídeo (BD Pharmingen, San Diego, CA).

As células foram incubadas à temperatura ambiente, protegidas da luz por 15 minutos. Após esse período, as células foram ressuspendidas em $400 \mu \mathrm{l}$ de Annexin V binding buffer (BD Biosciences, San Jose, CA) e adquiridas imediatamente por citometria de fluxo. A aquisição dos dados foi realizada utilizando o citometro de fluxo FACS ARIA. Para esta análise foram utilizados os softwares FACSDIVA (BD Biosciences, San Jose, CA) e FLOWJO (TreeStar, Ashland, OR).

\subsection{2-Cytospin}

Para análise citoquímica foi realizada a técnica cytospin, onde uma amostra de $100 \mu 1$ contendo $10^{5}$ células diluídas em Mc1 foi fixada a uma lâmina previamente preparada da seguinte maneira: a amostra foi colocada em um recipiente plástico acoplado sobre uma lâmina de vidro recoberta com papel filtro vazado. Este sistema foi centrifugado em uma citocentrífuga por 5 minutos a 1000rpm, para fixar a amostra na lâmina de maneira uniforme em uma área delimitada.

Para a coloração, foi utilizado o corante de Rosenfeld (Rosenfeld, 1977) que é um corante pancromático para hematologia e citologia clínica, cuja composição é a combinação de May-Grünwald e Giemsa. Este corante marca o núcleo em violetaavermelhado, o citoplasma basófilo em azul, o citoplasma acidófilo em vermelho e as granulações basófilas se coram em violeta-escuro.

O corante foi deixado sobre a lâmina por 2 minutos em seguida foi adicionado tampão fosfato por 6 minutos. O tampão fosfato era composto por: $20 \mathrm{~g}$ de fosfato de sódio bibásico e $25 \mathrm{~g}$ fosfato de potássio monobásico. Após a coloração as lâminas foram observadas por microscopia ótica nos aumentos de 10x, 20x, 40x e 60x. 


\subsection{3-Ensaio clonogênico}

Os ensaios clonogênicos foram realizados para avaliar a capacidade das CTHs e progenitores funcionais formarem colônias nos dias 0 e 3, após o co-cultivo com CTMs de diferentes idades. Foram inoculadas $1 \times 10^{3}$ células para cada $1000 \mu 1$ de meio Methocult H4434 (Stem Cell Technologies, Vancouver,Canada) em placa de 6 poços, na qual foram mantidas a $37^{\circ} \mathrm{C}, 5 \% \mathrm{CO}_{2}$ em incubadora umidificada por 14 dias. Após esse período as colônias foram contadas e especificadas como: BFU-E (eritrócitos), CFU-GM (granulócitos e macrófagos), CFU-M (megacariócitos) e CFU-GEMM (granulócitos, macrófagos, eritrócitos e megacariócitos).

\subsection{4- Análise imunofenotípica da expressão do receptor CXCR4}

A análise imunofenotípica do receptor CXCR4 foi realizada após o descongelamento de células LMN em solução de descongelamento Mc3. Em seguida foi realizada a contagem e a análise da viabilidade das células por câmara de Neubauer utilizando o Azul de Tripan. Após a contagem e análise, as células foram marcadas com os anticorpos monoclonais Lin- FITC, CD34-PE-Cy7 (clone: 8G12) e CD117-APC (clone: 104D2) (BD Pharmingen, San Diego, CA), CXCR4- PE (clone: 12G5) (BD Pharmingen, San Diego, CA) e CD45 PerCP-Cy5.5 (clone: J33) (Beckman Coulter, Marselle, France). A aquisição das amostras foi realizada no citometro de fluxo FACS ARIA e foram adquiridos pelo menos 10.000 eventos por tubo.

Para esta análise foram utilizados os softwares FACSDIVA (BD Biosciences, San Jose, CA) e FLOWJO (TreeStar, Ashland, OR).

\subsection{5- ELISA}

Para a detecção da quimiocina CXCL-12/SDF-1 no sobrenadante do controle e do co-cultivo de CTHs com CTMs de diferentes idades. Foi realizada a técnica quantitativa imunoenzimática sanduíche ELISA, para a qual foi utilizado o Kit Human CXCL12/SDF1 $\alpha$ da R\&D Systems. A técnica foi realizada com as amostras em duplicata da seguinte maneira:

Foram adicionados à microplaca $100 \mu 1$ do diluente RD1-55, logo em seguida adicionamos $100 \mu \mathrm{l}$ do sobrenadante do controle e do co-cultivo e as amostras foram 
incubadas por 2 horas à temperatura ambiente. Após o período de incubação, cada poço foi lavado 4 vezes com $400 \mu 1$ de Wash Buffer. Posteriormente, foi acrescentado $200 \mu 1$ de SDF-1 que permaneceu na placa em agitação por 2 horas, o procedimento de lavagem foi repetido novamente. Acrescentamos $200 \mu \mathrm{l}$ da solução de substrato em cada poço e incubamos por 30 minutos em temperatura ambiente protegido de luz. Foi adicionado $50 \mu \mathrm{l}$ de $\mathrm{H}_{2} \mathrm{SO}_{2}$ para parar a reação. Depois deste procedimento, a quantificação foi realizada pela leitura da absorbância pelo leitor de ELISA.

\subsection{6-Análise estatística}

As análises estatísticas foram realizadas no programa GraphPad Prisma. (GraphPad Software, San Diego, CA). O teste $t$-student foi utilizado para comparação entre 2 grupos e ANOVA para comparações de mais de 2 grupos, foi utilizado a correção de Bonferroni, quando necessário. Foi considerado significativo $\mathrm{p}<0,05 \mathrm{em}$ todos os experimentos. 


\section{6- RESULTADOS}

6.1- Parte I - Caracterização de células-tronco mesenquimais da medula óssea e CTHs provenientes de sangue de cordão

6.1.1- As CTMs isoladas preencheram todos os critérios estabelecidos pela Sociedade Internacional de Terapia Celular (ISCT).

As células obtidas a partir dos filtros de coleta de MO, foram submetidas Á análise imunofenotípica (Figura 6), bem como à da capacidade de diferenciação em condrócito (Figura 7A), adipócitos (Figura 7B) e osteócitos (Figura 7C), três linhagens de origem mesodérmica. Como esperado as células preencheram todos os requisitos da Sociedade Internacional de Terapia Celular (ISCT, do inglês, International Society for Cellular Therapy) comprovando que realmente eram células-tronco-mesenquimais. 


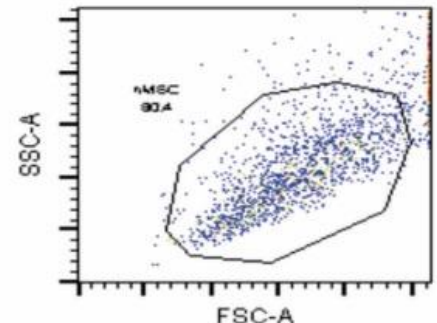

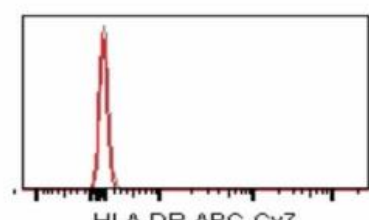

HLA-DR-APC-Cy?

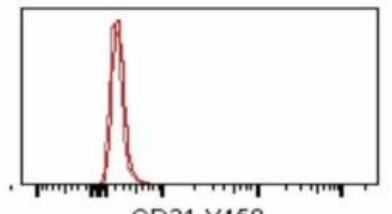

CD31-V450

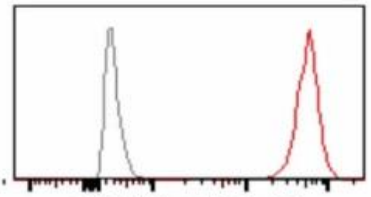

CD44-PerCP-Cy5.5

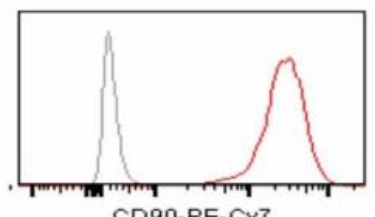

CD90-PE-Cy7
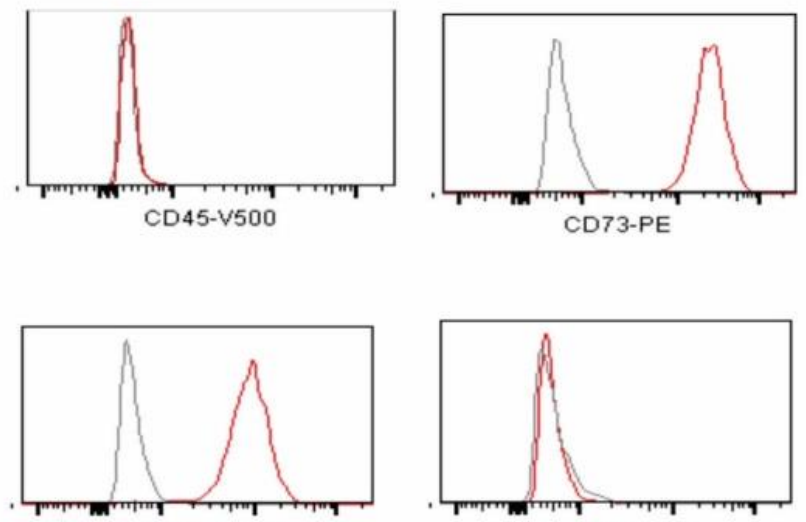

CD105-PE-CF594

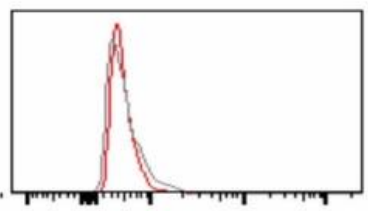

CD106-FITC

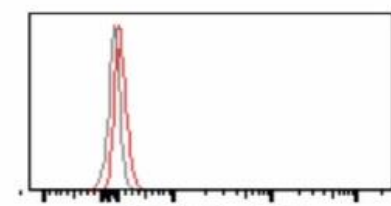

CD14-Alexa700

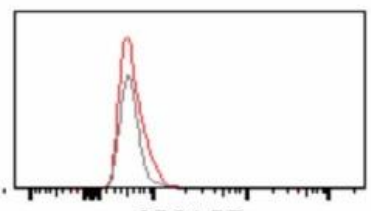

CD34-PE

Figura 6 - Perfil de expressão fenotípica de CTMs isoladas da MO. Estratégia de seleção populacional característica de células estromais (gate inicial), segundo o seu tamanho (FSC) versus granulosidade (SSC). Histogramas selecionados a partir do gate inicial mostram células sem marcação (linha cinza) e as células marcadas (linha vermelha). As células apresentaram 90\% de positividade para os marcadores CD29, CD44, CD73, CD90 e CD105. E são negativas para HLA-DR, CD14, CD31, CD34, CD45 e CD106, excluindo contaminação das culturas com células hematopoeticas e vasculares. 


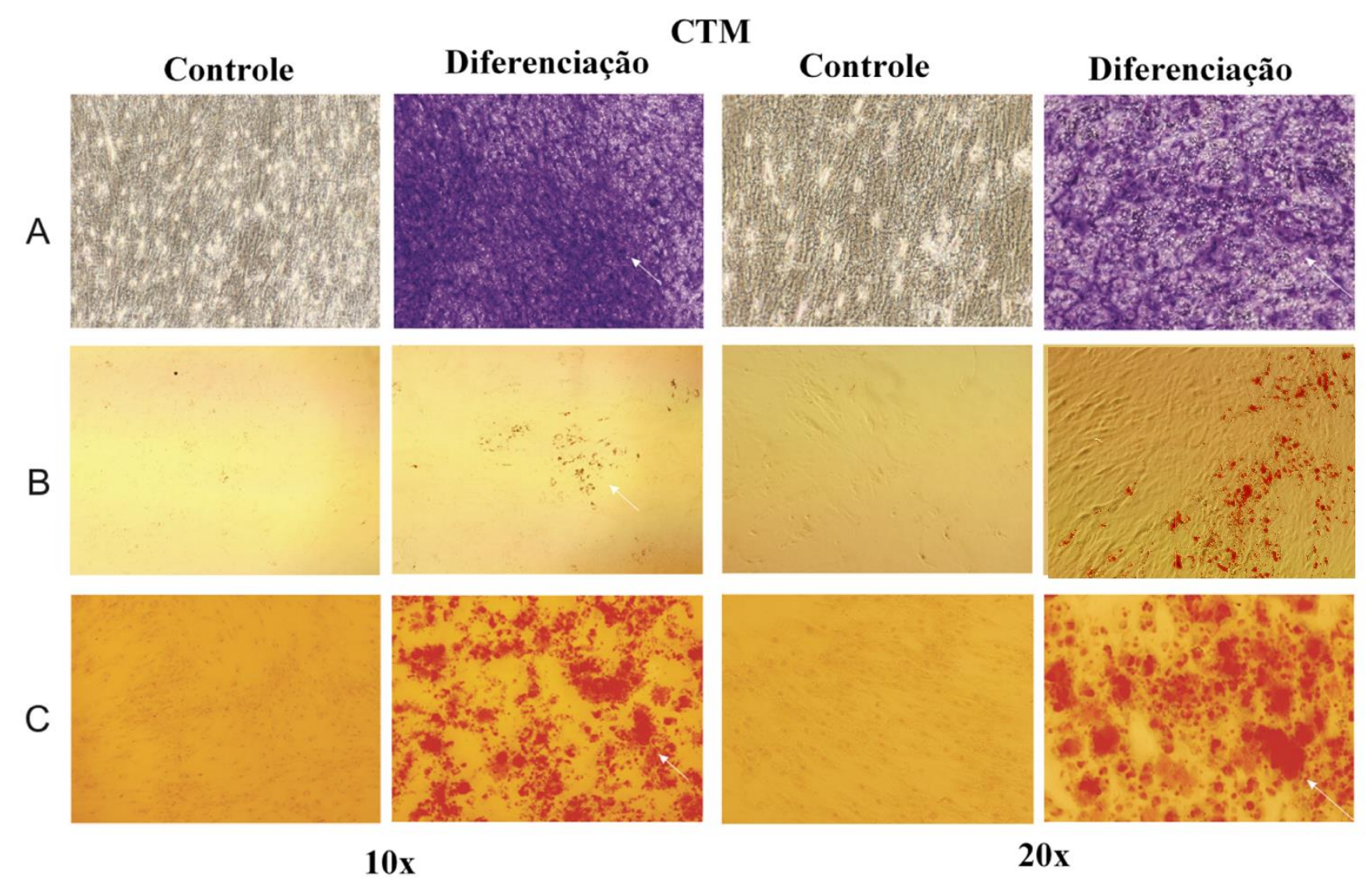

Figura 7- Diferenciação das CTMs em condrócitos, adipócitos e osteoblastos. (A) Coloração com azul de toluidina mostrando a formação da matriz de proteoglicanos na diferenciação condrogênica. (B) Formação de gotas lipídicas marcadas pelo corante Oil Red na diferenciação adipogênica. (C) Coloração da matriz de cálcio evidenciada pela marcação com o corante Alizarin red na diferenciação osteogênica. Células cultivadas na ausência de fatores de diferenciação foram denominadas controle e as células cultivadas com meio de diferenciação específico foram denominadas diferenciação. Aumento: 10x e 20x.

\subsection{2- CTHs isoladas e co-cultivadas com CTMs apresentam diferentes estágios de maturação}

As células progenitoras primitivas, são conhecidas pela capacidade de autorrenovação. Enquanto que as intermediárias e progenitoras hematopoéticas podem estar comprometidas com a linhagem mielóide, ou seja, são mais diferenciadas. Portanto as CTHs e suas subpopulações foram identificadas pela expressão ou ausência dos marcadores Lin, CD34, CD38 e CD117. As subpopulações progenitoras primitivas e intermediárias foram fenotipadas de acordo com a expressão Lin-CD34+CD38 ${ }^{+} /{ }^{-} \mathrm{CD} 117^{-}$ , enquanto as progenitoras foram identificadas como in $^{-} \mathrm{CD} 34^{+} \mathrm{CD} 38^{+} /{ }^{-} \mathrm{CD} 117^{+}$(Figura 8). 

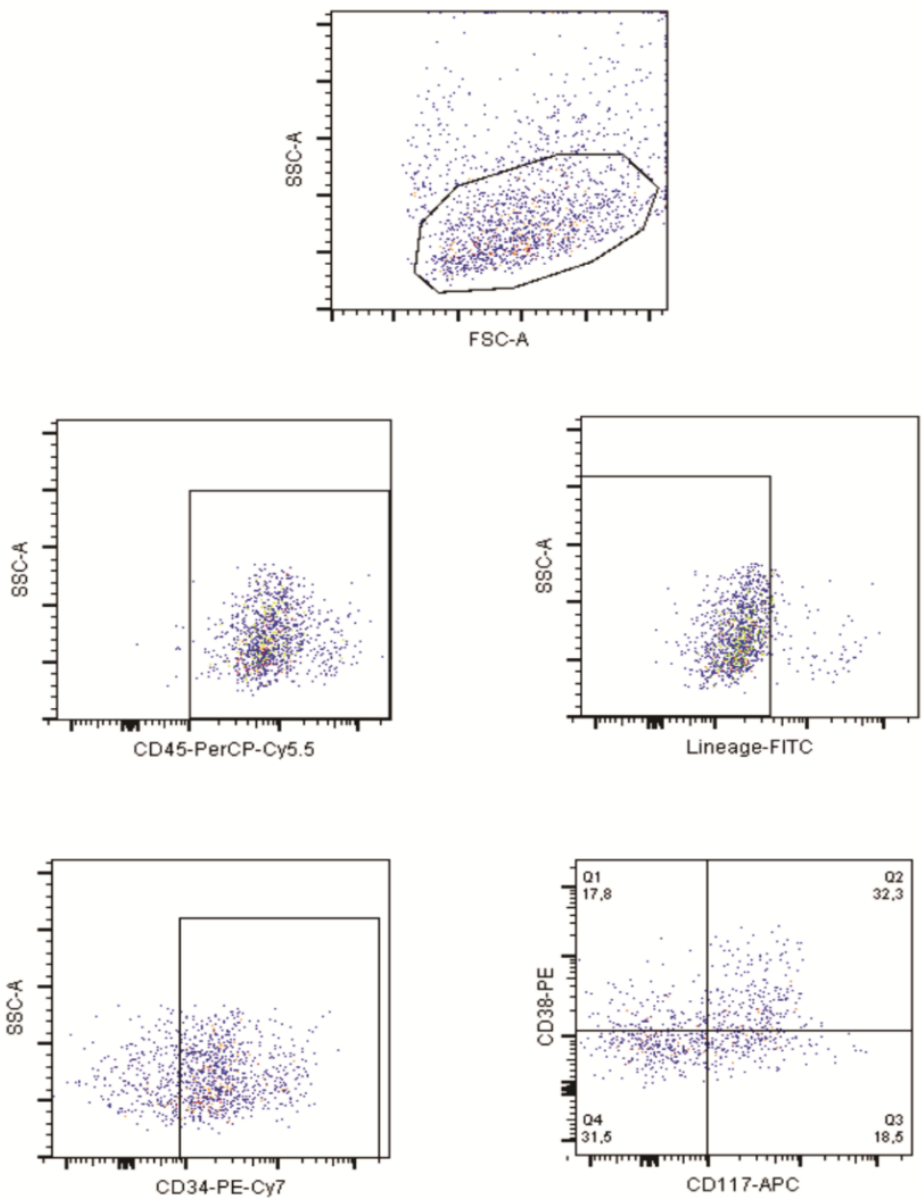

Figura 8 - Perfil de expressão fenotípica de CTHs e subpopulações. As células $\operatorname{Lin}^{-} \mathrm{CD} 34^{+}$foram quantificadas pelo protocolo ISHAGE (do inglês, International Society of Hematotherapy and Graft Engineering). As células foram marcadas com o anticorpo monoclonal anti-CD45 para delimitar a população total de leucócitos e posteriormente a população de células Lin-CD34+ foram selecionadas. A partir do gate de células Lin- e CD34+, as subpopulações de células foram caracterizadas pela expressão dos marcadores CD38 e CD117. 


\subsection{3- CTHs e CTMs são morfologicamente distintas}

Para avaliar a morfologia das CTHs e CTMs, foi realizada análise citoquímica das células utilizadas no ensaio de co-cultivo. Este dado nos mostrou que as células apresentaram diferenças em sua morfologia e tamanho. As CTHs possuem a membrana citoplasmática regular e o núcleo mais condensado diferente das CTMs que possuem a membrana citoplasmática irregular, citoplasma abundante e núcleo pequeno. Estas células também possuem tamanhos diferentes, as CTHs são menores que as CTMs (Figura 9).
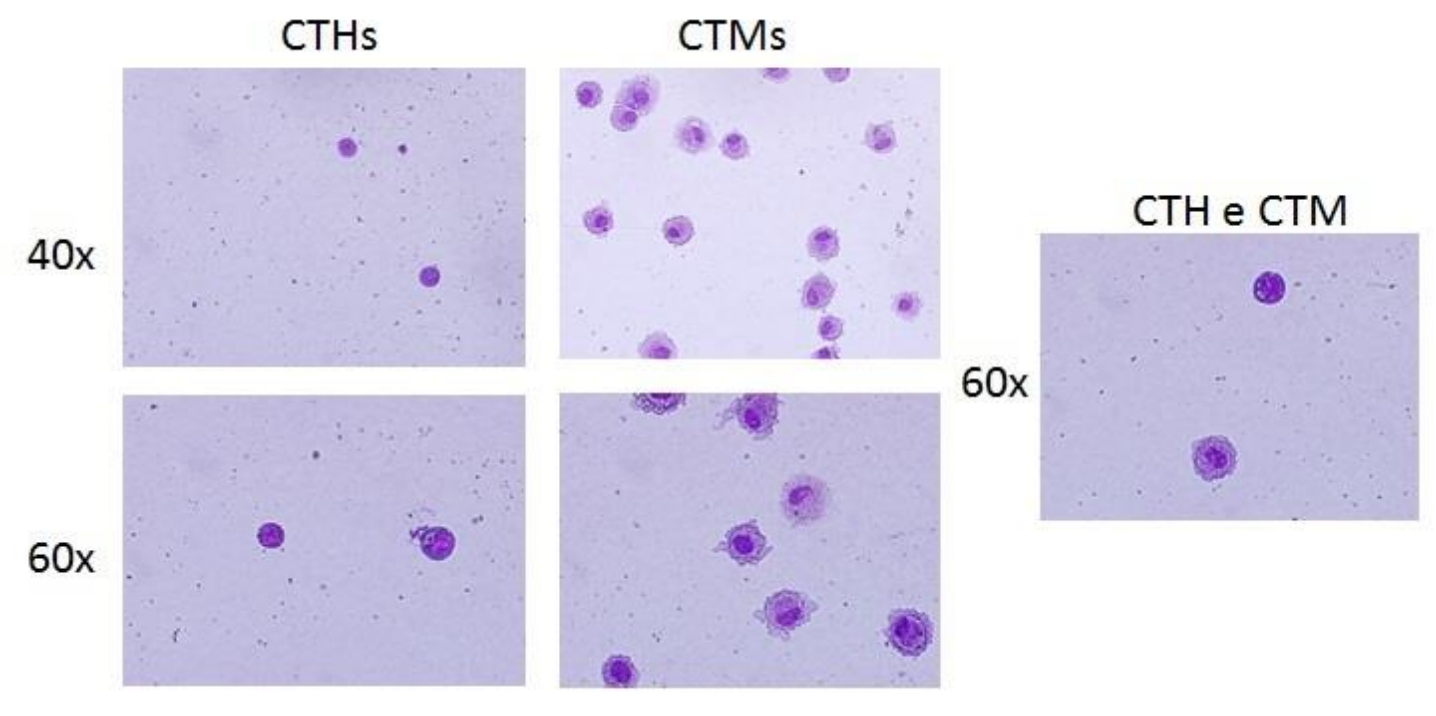

Figura 9- Análise citoquímica de CTHs e CTMs. Coloração realizada com corante de Rosenfeld, mostrando as diferenças morfológicas das células-tronco hematopoéticas (CTHs) e mesenquimais (CTMs).

\section{2- Parte II - Co-cultivo de CTHs de sangue de cordão umbilical com CTMs provenientes de doadores de medula}

Após o co-cultivo por três e sete dias, de CTHs com CTMs, as CTHs foram separadas e analisadas de acordo com a sua localização no poço de cultura. As células que estavam em suspensão no sobrenadante foram denominadas de fração "S", as que se encontravam aderidas à superfície das CTMs, fração "A”. Ambas foram comparadas com as CTHs cultivadas na ausência de CTMs as quais chamamos "C" (Controle). 


\subsection{1 - O co-cultivo das CTHs com CTMs favoreceu a manutenção da população de células indiferenciadas $\mathrm{Lin}^{-} \mathrm{CD}^{+} 4^{+}$, após sete dias de cultivo}

Os resultados da Figura 10, são referentes à percentagem de células Lin-CD34+ após o cultivo por três e sete dias de CTHs com CTMs.

No terceiro dia de cultivo, a percentagem de células Lin $^{-C D} 34^{+}$das frações $\mathbf{S}$ e $\mathbf{A}$ mantiveram-se similares ao C. Observamos que conforme o período de cultivo se ampliava, havia diferença significativa das células $\operatorname{Lin}^{-} \mathrm{CD} 34^{+}$nas condições $\mathbf{S}$ e $\mathbf{A}$ quando comparadas ao C. As CTHs em co-cultivo com CTMs por sete dias apresentaram uma percentagem maior de células $\operatorname{Lin}^{-} \mathrm{CD} 34^{+}$, sugerindo a influência das CTMs na manutenção do estado indiferenciado das CTHs.

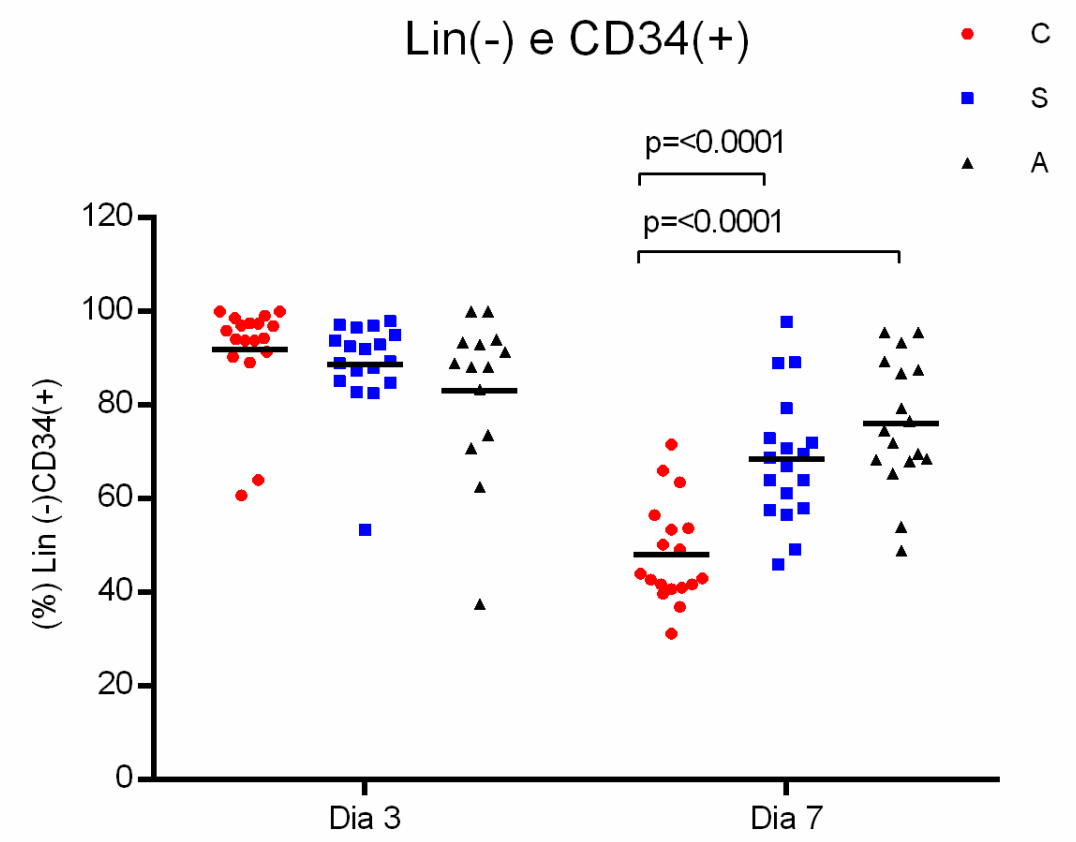

Figura 10- O co-cultivo das CTHs com CTMs favorece a manutenção da população de células indiferenciadas Lin- CD34+ após sete dias de cultivo - A percentagem de células Lin $^{-} \mathrm{CD}^{+} 4^{+}$foi de $91,91 \pm 11,22 \%$ em C, 88,7£10,12\% em $\mathbf{S}$ e em $\mathbf{A}$ de $83,2 \pm 17,07 \%$, não mostrando diferenças significativas entre as percentagens nas diferentes condições. Entretanto, após sete dias de cultivo, observamos que a população Lin $^{-} \mathrm{CD}^{+} 4^{+}$foi de $48,19 \pm 10,82 \%$, em C, de $68,49 \pm 13,73 \%$ em S e de $79,47 \pm 11,00 \%$ em A. Sendo estas diferenças significativas quando comparadas ao controle. Número amostral (CTMs $=18)$ 
6.2.2 - Não foram observadas diferenças significativas da população de células LinCD34+ após três dias de cultivo, quando as CTMs foram agrupadas por idade

Os resultados da Figura 11 (A-D), representam a percentagem de células LinCD34+ após serem cultivadas por três dias na ausência e presença de CTMs de doadores das seguintes faixas etárias: 0 a 20 anos, 21-40 anos, 41-60 anos e >61 anos de idade. A percentagem de células das frações $\mathbf{S}$ e $\mathbf{A}$ apresentaram-se similares ao $\mathbf{C}$, portanto não houve diferenças significativas.

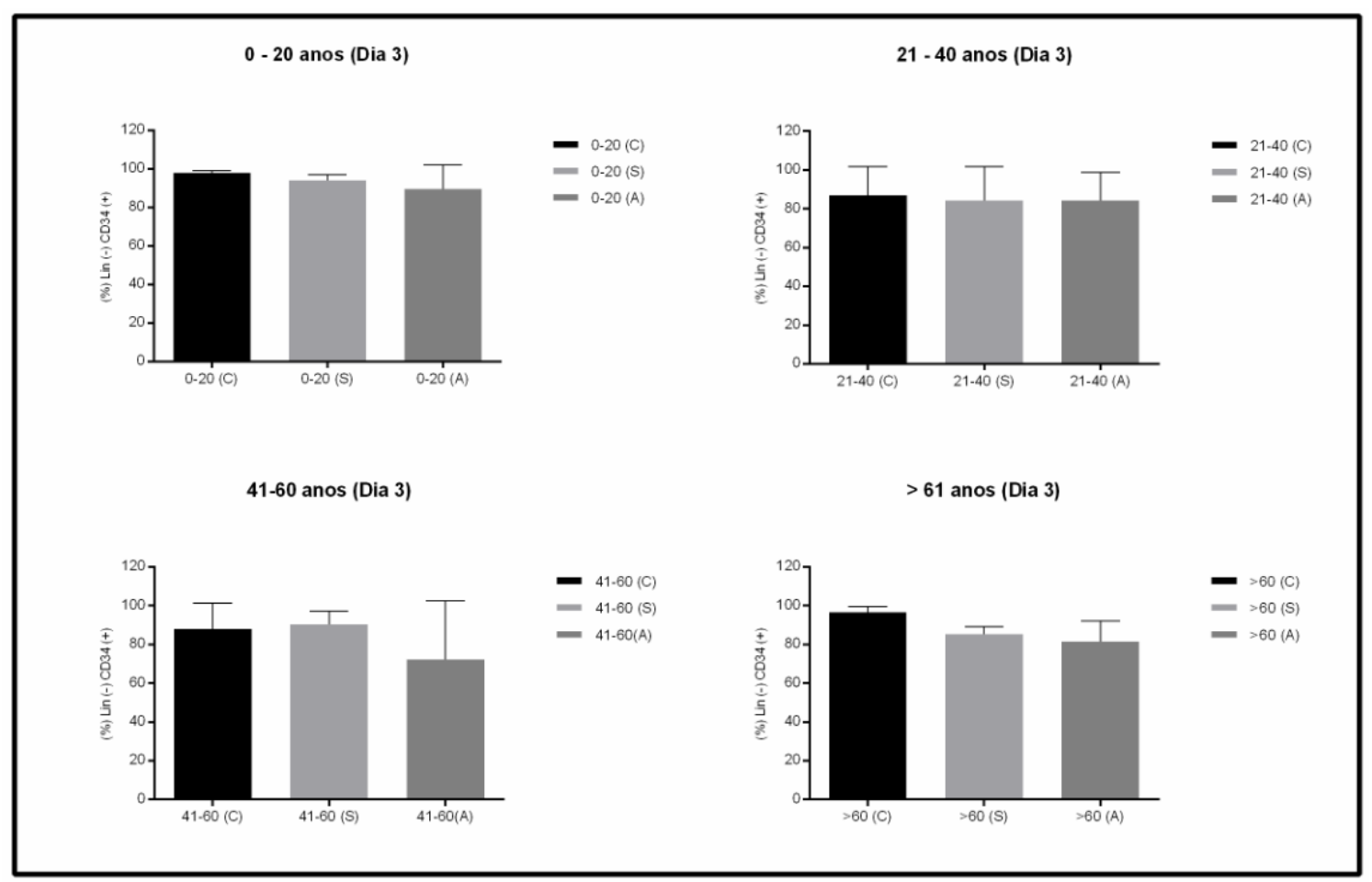

Figura 11 (A-D) - Percentagem de células Lin-CD34+ agrupadas por idade no terceiro dia de cocultivo. Os dados representados nestes gráficos não apresentaram diferenças significativas. 


\subsection{3 - O co-cultivo das CTHs com CTMs favoreceu a manutenção da população de células indiferenciadas $\mathrm{Lin}^{-} \mathrm{CD34}^{+}$na fração A após sete dias de cultivo, quando as CTMs foram agrupadas por idade}

Os resultados da Figuras 12 (A-D), representam a percentagem de células LinCD34+ após serem cultivadas por sete dias na ausência e presença de CTMs de doadores de diferentes idades.

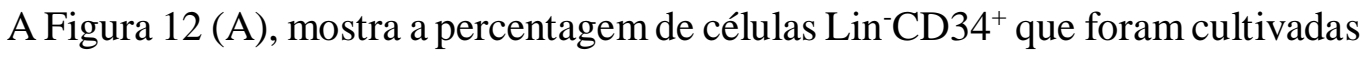
por sete dias com CTMs de doadores de idades de 0 a 20 anos. Estes dados mostram uma diferença significativa na percentagem de células $\operatorname{Lin}^{-C D} 34^{+}$da fração A quando comparadas ao $\mathbf{C}$.

As Figuras 12 (B- D) mostra a percentagem de células Lin $^{-C D} 34^{+}$que foram cultivadas por sete dias com CTMs de doadores de idade de 21-40, 41-60 e > 61 anos. Não foram observadas diferenças significativas nestes grupos.

Estes dados sugerem aumento na capacidade das CTHs em manterem seu fenótipo indiferenciado quando em contato com CTMs mais jovens. 


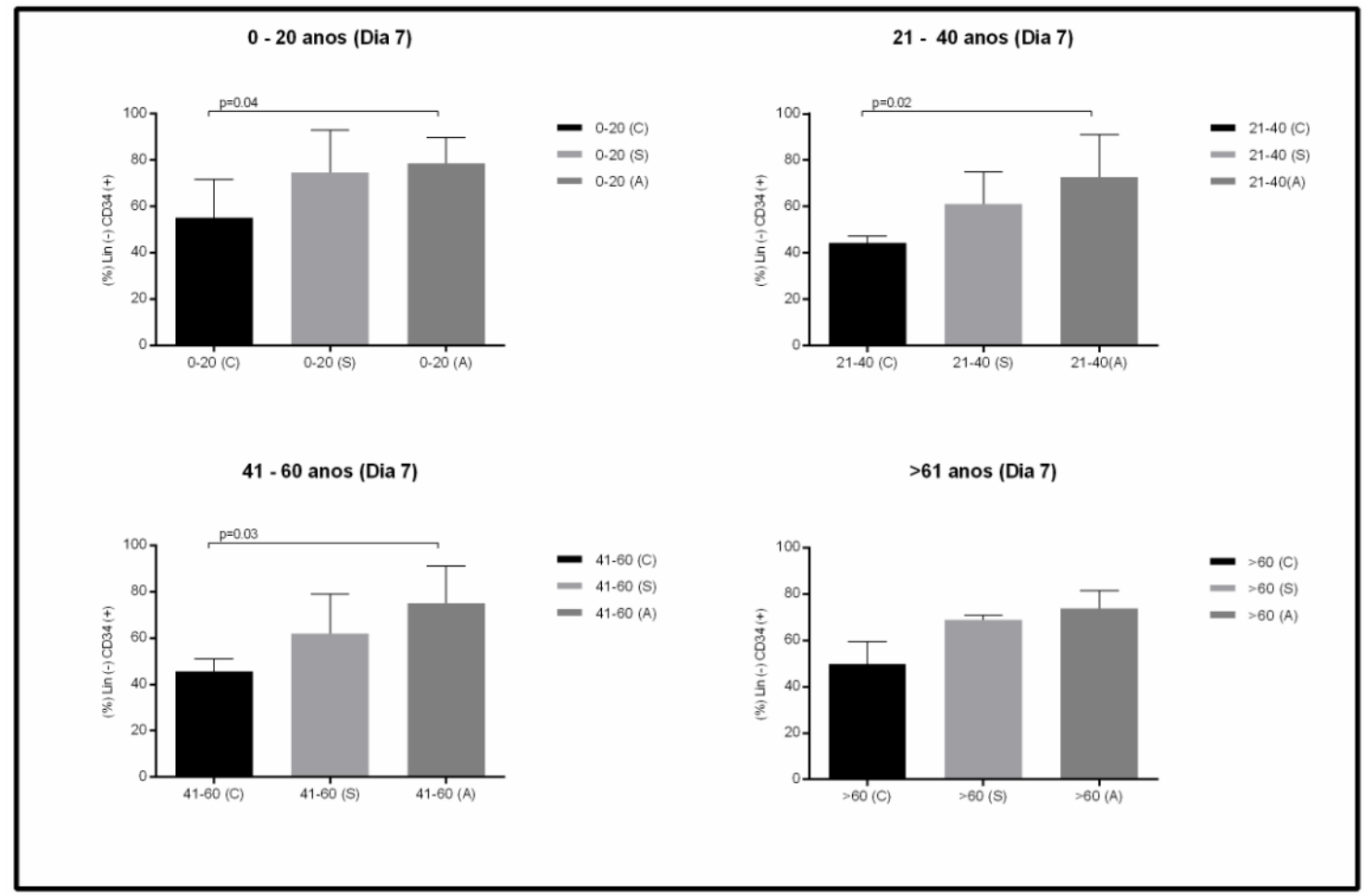

Figura 12 - A percentagem de células Lin-CD34+ da fração A aumenta, quando CTHs são cultivadas com CTMs de doadores de 0-20 anos por sete dias. (A) A percentagem de células Lin ${ }^{-C D} 34^{+}$do grupo

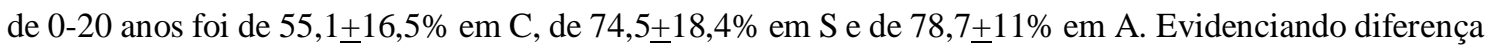
significativa nestas frações quando comparadas ao controle. (B-D) Nos demais grupos, não houve diferença significativa. Número amostral de CTMs por grupos - (0-20 anos = 6), (21-40 anos =5), (41-60 anos = 5), $(>61$ anos $=2)$.

\subsection{4 - CTMs mantêm as subpopulações de CTHs com perfil mais indiferenciado no terceiro e sétimo dia de co-cultivo.}

Os resultados da Figura 13 (A-B) representa a percentagem das subpopulações de células progenitoras primitivas e intermediárias $\left(\mathrm{CD} 38^{+} \%^{-} \mathrm{CD} 117^{-}\right)$e progenitoras $\left(\mathrm{CD} 38^{+} /^{-} \mathrm{CD} 117^{+}\right)$após o cultivo por três e sete dias na ausência e presença de CTMs.

No terceiro dia de cultivo, houve diferença significativa na percentagem de células progenitoras primitivas e intermediárias nas frações $\mathbf{S}$ e $\mathbf{A}$ quando comparadas ao $\mathbf{C}$. Além disso, observamos diminuição da subpopulação de células progenitoras, sugerindo que CTHs mantêm seu fenótipo mais indiferenciado quando cultivadas com CTMs. 
A

Subpopulações

Dia 3

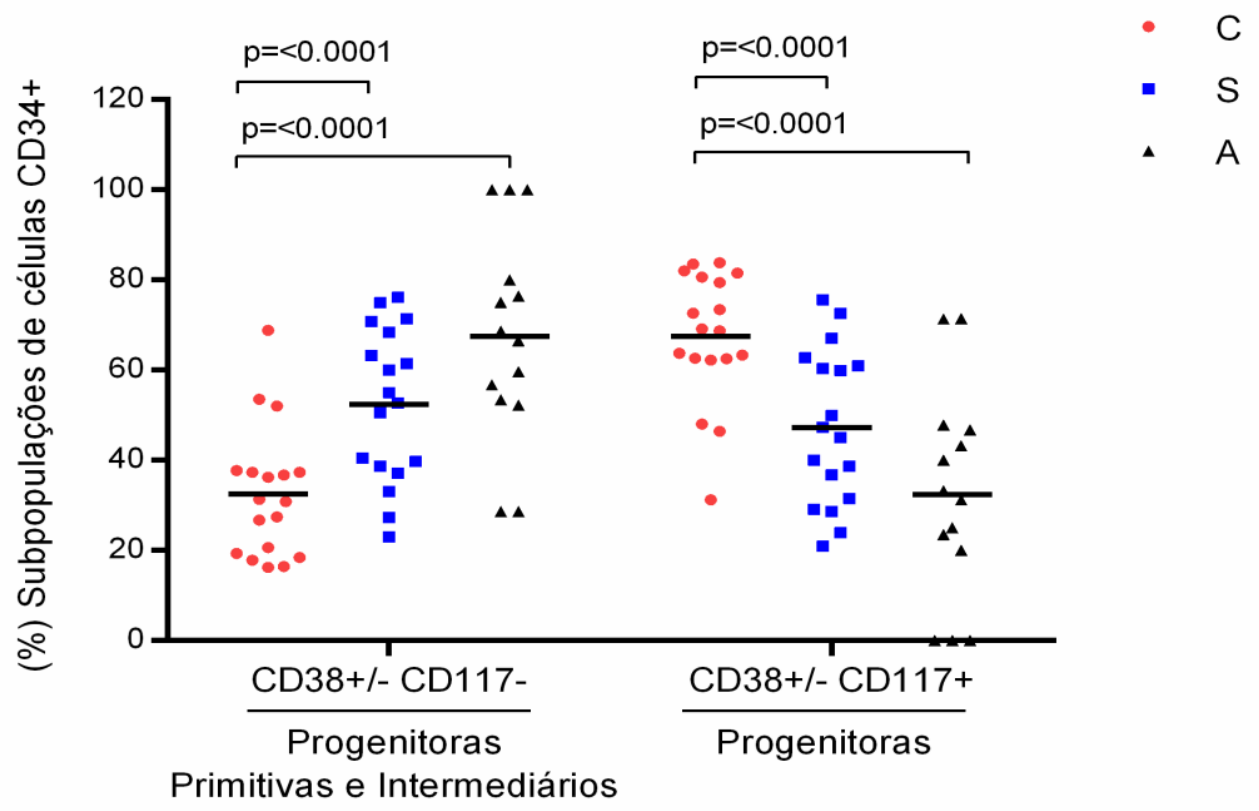

Figura 13A - A percentagem de células progenitoras primitivas e intermediárias é maior quando cultivadas por três dias com CTMs. A percentagem de células progenitoras primitivas e intermediárias foi de $32,5 \pm 14 \%$ em $\mathbf{C}, 52 \pm 17 \%$ na fração $\mathbf{S}$ e $67,5 \pm 23 \%$ na fração $\mathbf{A}$, mostrando diferença significativa nas diferentes condições. A percentagem de células progenitoras foi de $67,5 \pm 14 \%$ em C, $47 \pm 17 \%$ na fração S e $32 \pm 23 \%$ em A. Estes dados são significativos quando comparados ao controle (Número amostral $\mathrm{CTMs}=18)$.

No sétimo dia de cultivo, as células progenitoras primitivas e intermediárias da fração A, apresentaram diferenças significativas quando comparadas ao $\mathbf{C}$. Além disso, a percentagem de células progenitoras foi menor nesta condição quando comparada a $\mathbf{C}$, indicando que as CTMs influenciam a manutenção do estado indiferenciado das CTHs mesmo quando o tempo de cultivo se amplia. 


\section{Subpopulações}

Dia 7

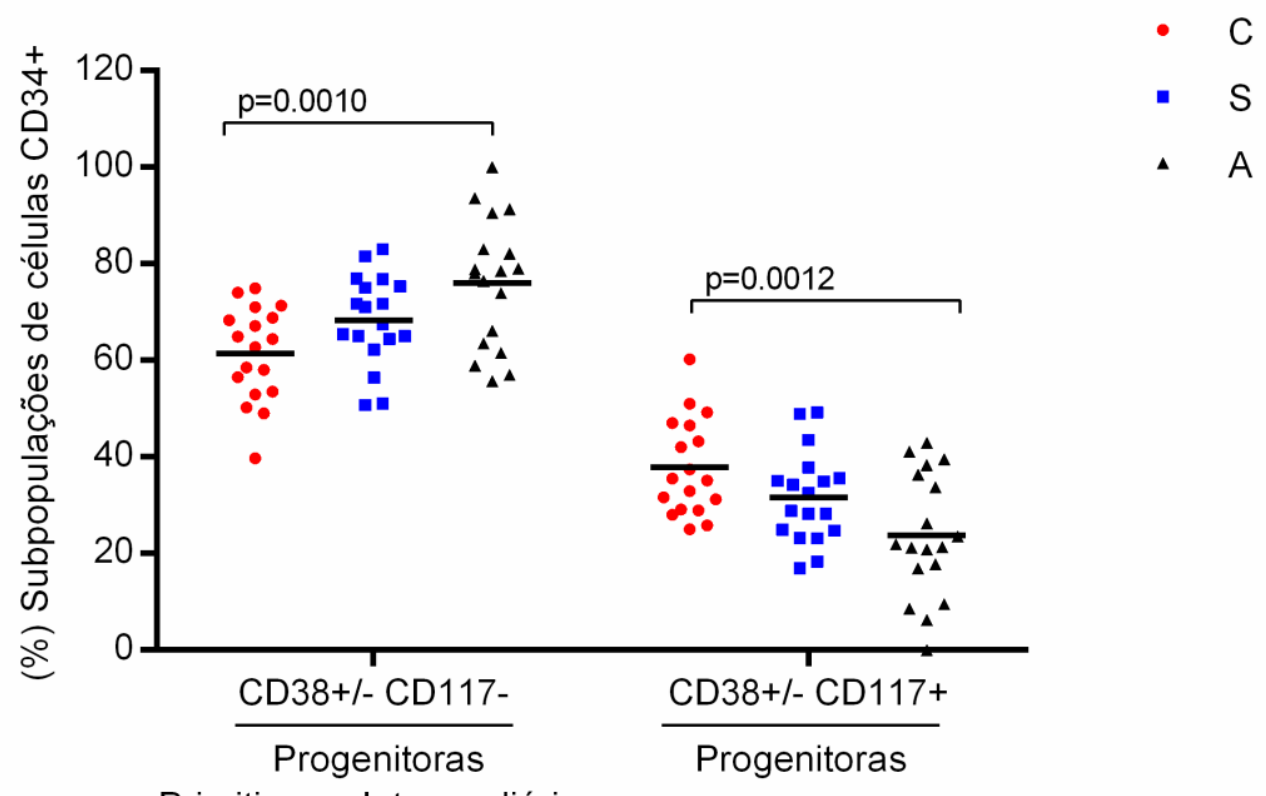

Figura 13B - A percentagem de células progenitoras primitivas e intermediárias é maior no sétimo dia de cultivo com CTMs. A percentagem de células progenitoras primitivas e intermediárias foi de $61 \pm 10 \%$ em C, $68 \pm 9 \%$ em S e 76+13\% na fração A, mostrando diferença significativa nas percentagens da fração A. Além disso, também observamos menor percentagem de células progenitoras na fração A, que foi de $38 \pm 10 \%$ em C, $32 \pm 9 \%$ em S e $24 \pm 13 \%$ em A, mostrando maior percentagem de células diferenciadas na ausência de CTMs. Estes resultados são significativos quando comparados ao controle. (Número amostral- CTMs $=18$ )

\subsection{5 - CTMs de indivíduos de diferentes idades mantêm o estado indiferenciado de CTHs, após o terceiro e o sétimo dia de cultivo.}

Os dados a seguir representam a percentagem de subpopulações de células cultivadas no período de três dias com CTMs de diferentes idades.

$\mathrm{Na}$ Figura 14 (A) observamos que a percentagem de células progenitoras primitivas e intermediárias é maior na fração A em CTHs cultivadas com CTMs de indivíduos de 0-20 anos, quando comparadas ao controle. Além disso, observamos menor percentagem de células progenitoras mais diferenciadas na fração $\mathbf{A}$ quando a comparamos com o $\mathbf{C}$. 
A Figura 14 (B) mostra a percentagem de células cultivadas com CTMs de indivíduos de 21-40 anos, onde foi observada diferença significativa de células progenitoras primitivas e intermediárias tanto na fração $\mathbf{S}$ quanto na $\mathbf{A}$ em relação ao $\mathbf{C}$. Além disso, observamos menor percentagem de células progenitoras mais diferenciadas nas frações $\mathbf{A}$ e $\mathbf{S}$ comparadas ao $\mathbf{C}$.

As Figuras 14 (C e D) mostram a percentagem de subpopulação de células cultivadas com CTMs de indivíduos entre 41-60 e > 61 anos, respectivamente. Ambos não apresentaram resultados significativos.

Estes resultados sugerem que CTMs de indivíduos mais jovens influenciam a manutenção do fenótipo imaturo em CTHs. 
A

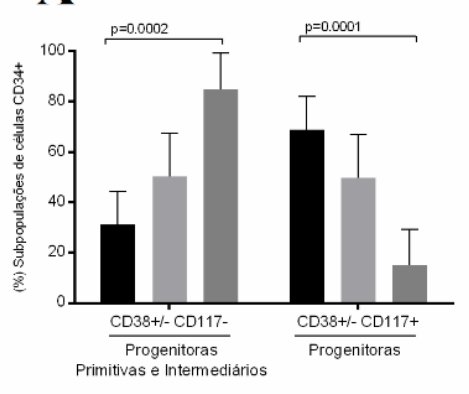

C

$41-60$ anos (Dia 3)

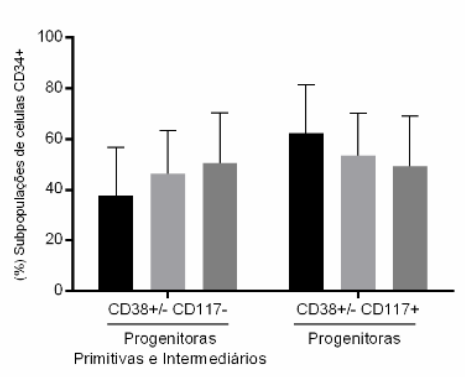

B
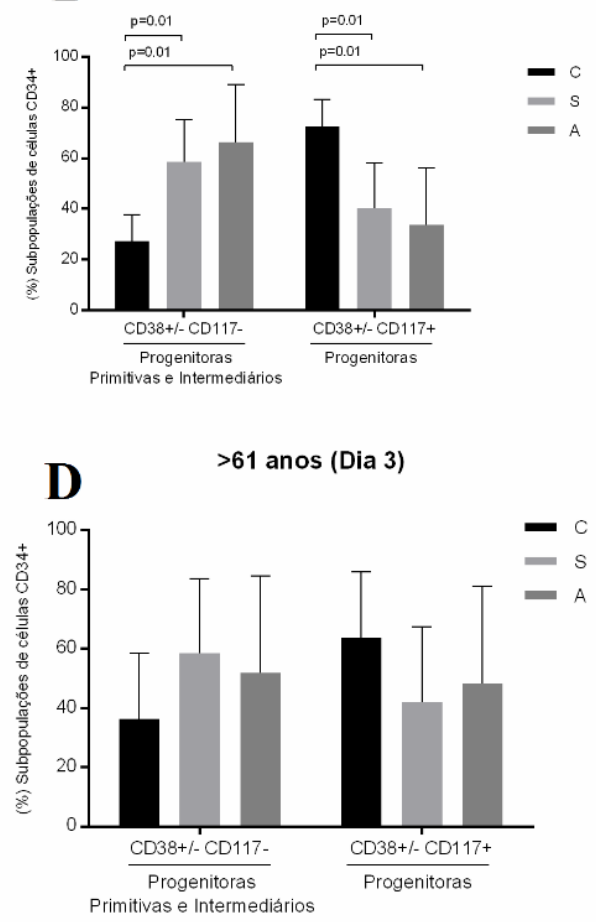

Figura 14 - CTMs de indivíduos de diferentes idades mantêm o estado indiferenciado de CTHs, após o terceiro dia de cultivo. (A) A percentagem de células progenitoras primitivas e intermediárias foi maior no grupo de $0-20$ anos. (CTRL $=31,1 \pm 13,2 \%)$ e $(A=85 \pm 14,2 \%)$. A percentagem de progenitoras foi menor. $(\mathrm{CTRL}=68,8+13,2 \%)$ e $(\mathrm{A}=14,9 \pm 14,2 \%)$. (B) No grupo de 21-40 observamos maior percentagem de células progenitoras primitivas e intermediárias nas condições $(\mathrm{S}=58,7 \pm 16,4 \%)$ e $(\mathrm{A}=66,3 \pm 22,6 \%)$ comparadas ao $(\mathrm{C}=27,4 \pm 10,4 \%)$, e menor percentagem de células progenitoras $(\mathrm{S}=40,4 \pm 17,5 \%)$ e $(\mathrm{A}=$ $33,6 \pm 22,6 \%)$ comparadas ao $(C=72,5 \pm 10,4 \%)$.(C-D) Os grupos de 41-60 e >61 anos não apresentaram diferenças significativas. Número amostral de CTMs por grupos - $(0-20$ anos $=6),(21-40$ anos $=5),(41-60$ anos $=5),(>61$ anos $=2)$.

Os dados a seguir representam a percentagem de subpopulações de células cultivadas no período de sete dias com CTMs de diferentes idades.

A Figura 15 (A) mostra os dados de células cultivadas com CTMs de indivíduos entre 0-20 anos de idade. A subpopulação de células progenitoras primitivas e intermediárias da fração A é maior, mas a de células progenitoras é menor quando comparadas ao C. As Figuras 15 (B-D) mostram a percentagem de células cultivadas com CTMs de indivíduos, cuja faixa etária é de (21-40), (41-60) e (>61) anos. Estes dados não apresentaram significância estatística. 
Conforme o cultivo se amplia somente CTMs de indivíduos de 0-20 anos apresentaram diferença significativa nas células mais imaturas. Sugerindo maior capacidade de CTMs mais jovens em manterem CTHs com um fenótipo imaturo.

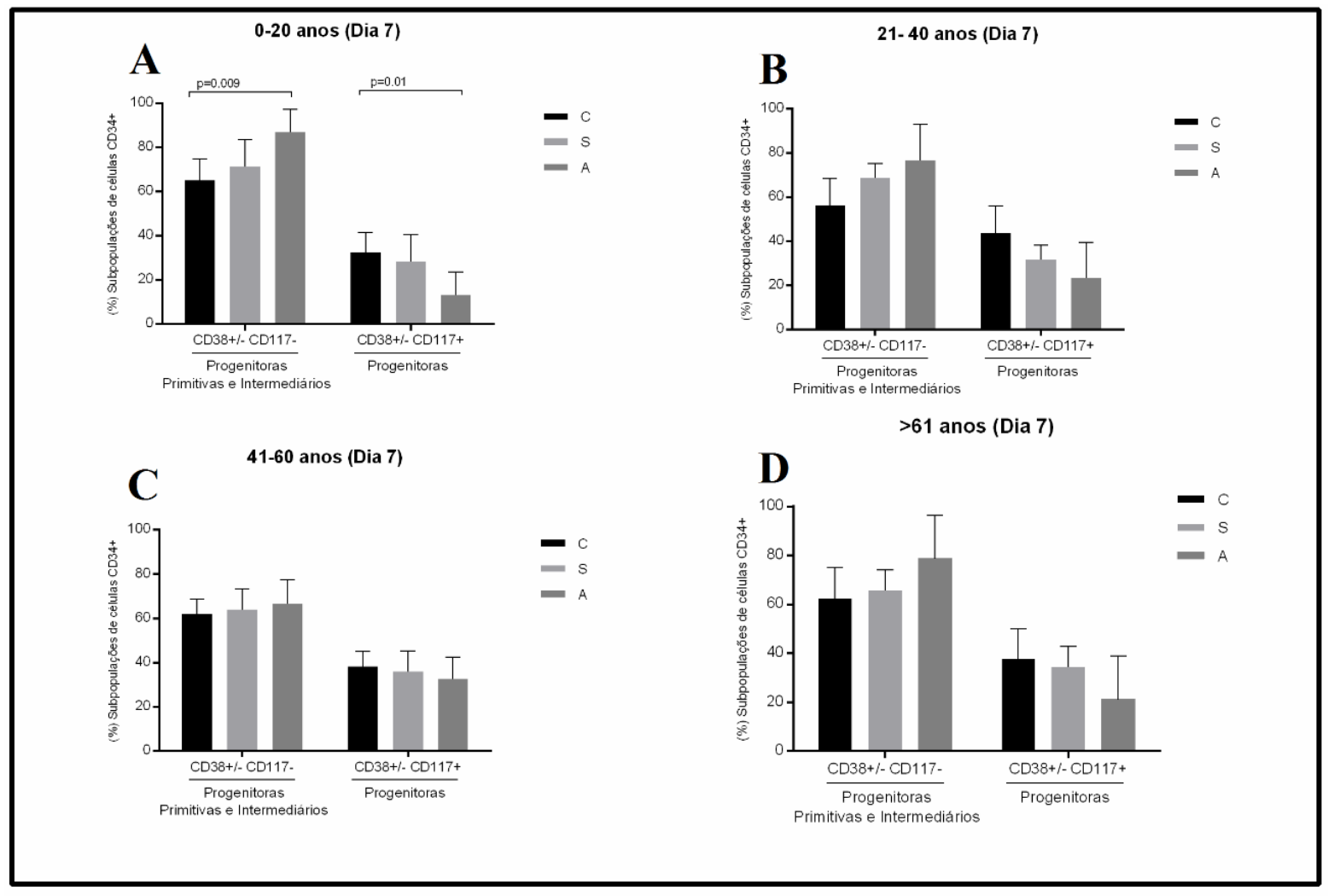

Figura 15 - CTMs de indivíduos mais jovens mantém o estado indiferenciado de CTHs, após o sétimo dia de cultivo. (A) A percentagem de células progenitoras primitivas e intermediárias foi maior na fração $(A=86,7 \pm 10,5 \%)$ do grupo de $0-20$ anos quando comparadas ao $(C T R L=66,1 \pm 9,5 \%)$. A subpopulação de células progenitoras foi menor em $(\mathrm{A}=13,2 \pm 10,4 \%)$ quando comparada ao (CTRL= 32,5 $\pm 9 \%)$. (B-D) Os grupos de 21- 40, 41-60 e >61 anos não apresentaram diferenças significativas. Número amostral de CTMs por grupos $-(0-20$ anos $=6),(21-40$ anos $=5),(41-60$ anos $=5),(>61$ anos $=2)$.

\subsection{6 - O co-cultivo de CTHs com CTMs de diferentes idades influenciou na} quantidade de CXCL-12 no sobrenadante do terceiro e sétimo dia de cultivo.

Os dados abaixo, representam a quantidade da quimiocina CXCL-12 no sobrenadante do co-cultivo de CTHs com CTMs no terceiro e sétimo de cultivo. A quantidade de CXCL-12 secretada foi maior nos sobrenadantes do co-cultivo em relação ao $\mathbf{C}$ (apenas CTHs). Observamos que conforme o tempo de cultivo se amplia, a quantidade de CXCL-12 presente no meio aumenta. Este resultado indica que as CTMs possuem um papel importante na produção desta quimiocina. 


\section{CXCL12 (SDF-1)}

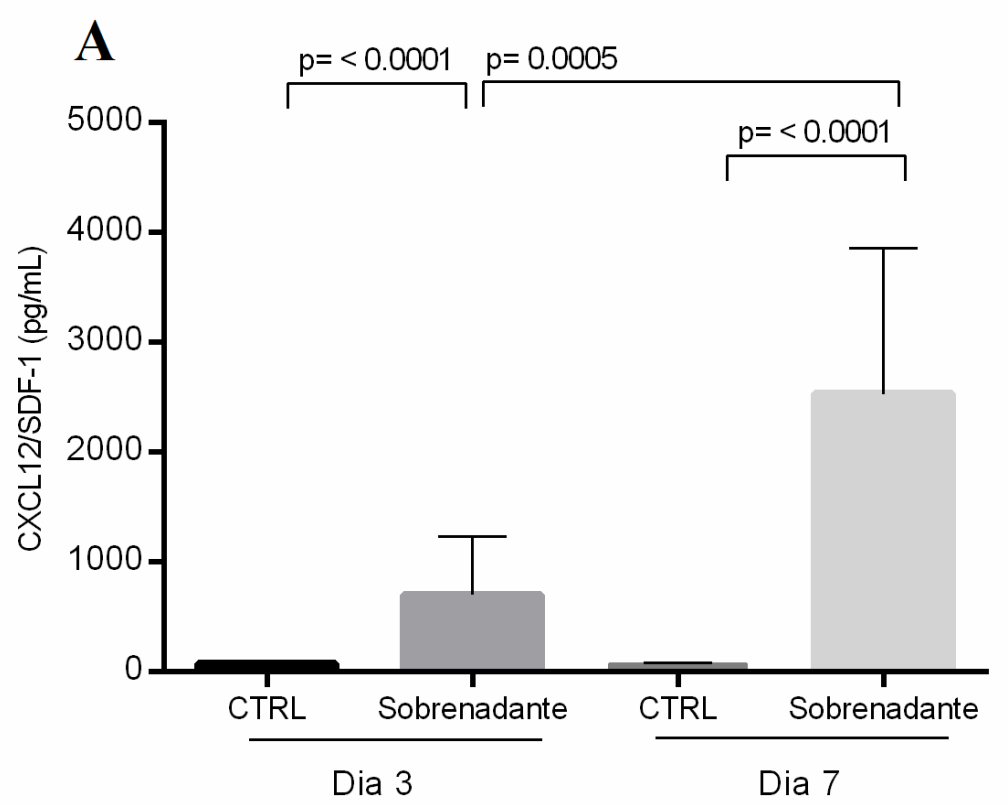

Figura 16A - Quantidade de CXCL-12 é maior no co-cultivo de CTHs com CTMs no terceiro e sétimo dia de cultivo quando comparada ao controle. No terceiro dia de cultura, a quantidade de CXCL-12 no sobrenadante $(\mathrm{S}=698,7 \mathrm{pg} / \mathrm{mL} \pm 528 \mathrm{pg} / \mathrm{mL})$ do co-cultivo com CTMs é significativamente maior que apenas nas CTHs (controle) $(\mathrm{CTRL}=71,7 \mathrm{pg} / \mathrm{mL} \pm 1,75 \mathrm{pg} / \mathrm{mL})$. O mesmo acontece no sétimo dia de cultivo, a quantidade de CXCL12 no sobrenadante $(\mathrm{S}=2527,0 / \mathrm{mL} \pm 1328,1 \mathrm{pg} / \mathrm{mL})$ é significativamente maior que no controle $(\mathrm{CTRL}=71,8 \mathrm{pg} / \mathrm{mL} \pm 4,35 \mathrm{pg} / \mathrm{mL})$. (Número amostral-20)

A Figura 16 (B), mostra a quantidade de CXCL-12 secretada no sobrenadante do cultivo de CTHs e CTMs isoladas (controles) e no co-cultivo de CTHs com CTMs de indivíduos de diferentes idades no período de três dias. Neste experimento, cultivamos CTHs na presença e ausência de CTMs e CTMs isoladas nas mesmas condições, a fim de observar se a quimiocina CXCL-12 era secretada por CTMs, CTHs ou ainda se esta secreção dependia de contato.

O sobrenadante do co-cultivo dos grupos 21-40 e 41-60 anos apresentaram aumento na secreção de CXCL-12 quando comparados aos controles. Ao realizarmos comparações entre os grupos, a quantidade de CXCL-12 no sobrenadante do grupo 0-20 era menor quando comparado ao do grupo 41-60 anos, porém, quando comparamos este último com o de >61 anos, observamos diminuição significativa na secreção de CXCL12 pelo grupo de >61anos. Sugerindo que a idade das CTHs influência de forma significativa na secreção de CXCL-12. 
Nossos resultados sugerem que a idade do indivíduo, no qual as CTMS foram isoladas tem influência no resultado da produção da CXCL-12.

B

CXCL12 (SDF-1)

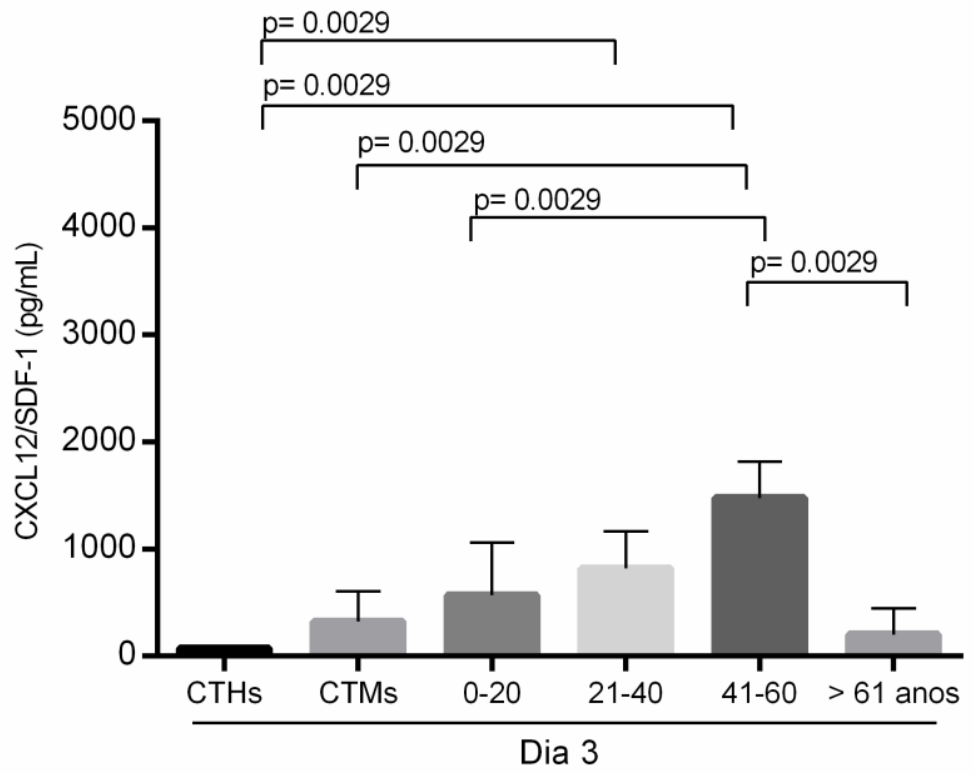

Figura 16B - Quantidade de CXCL-12 nos controles e nos co-cultivos de CTHs com CTMs de diferentes idades. No terceiro dia de co-cultivo, observamos aumento na quantidade de CXCL-12 no sobrenadante dos grupos $(0-20=569,61 \mathrm{pg} / \mathrm{mL} \pm 491,12 \mathrm{pg} / \mathrm{mL}),(21-40=820,24 \mathrm{pg} / \mathrm{mL} \pm 343,39 \mathrm{pg} / \mathrm{mL})$, $(41-60=1475,17 \mathrm{pg} / \mathrm{mL} \pm 342,33 \mathrm{pg} / \mathrm{mL})$ quando comparadas aos controles. (CTHs= 71,78pg/mL \pm $1,75 \mathrm{pg} / \mathrm{mL})$ e $(\mathrm{CTMs}=321,55 \mathrm{pg} / \mathrm{mL} \pm 283,40 \mathrm{pg} / \mathrm{mL})$ cultivadas isoladamente, exceto pelo grupo $(>61$ anos $=202,50 \mathrm{pg} / \mathrm{mL} \pm 244,65 \mathrm{pg} / \mathrm{mL}$ ) no qual não há diferença significativa quando comparado a qualquer dos controles. Número amostral = CTHs (04), CTMs (04), e co-cultivos 0-20 (04), 21-40 (04), 41-60 (03) e $>61$ anos (02).

Os dados a seguir representam a quantificação de CXCL-12 no sobrenadante do cultivo de CTHs com CTMs de diferentes idades, no período de sete dias.

Notamos que nos grupos de co-cultivo com CTMs de 21-40 e 41-60 anos ocorreu aumento significante na secreção de CXCL-12 quando comparamos com CTHs e CTMs cultivadas isoladamente, mostrando que o co-cultivo induz o aumento na secreção de CXCL-12. Os dados mostram secreção crescente de CXCL12 conforme a idade das CTMs de co-cultivo, exceto pelas CTMs $>61$ anos, onde notamos uma queda brusca na produção desta quimiocina. 


\section{CXCL12 (SDF-1)}

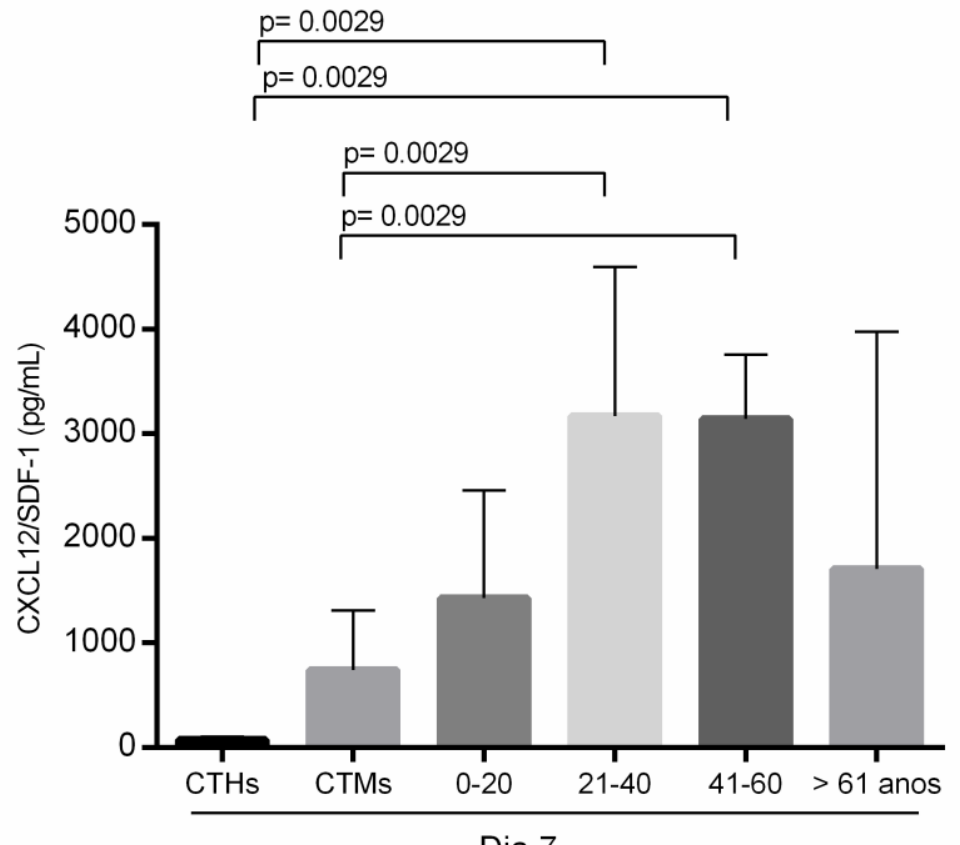

Dia 7

Figura 16C - Quantidade de CXCL-12 nos controles e nos co-cultivos de CTHs com CTMs de diferentes idades. No sétimo dia de co-cultivo, observamos aumento na quantidade de CXCL-12 no sobrenadante dos grupos $(21-40=3169,48 \mathrm{pg} / \mathrm{mL} \pm 1422,27 \mathrm{pg} / \mathrm{mL}), \quad(41-60=3138,05 \mathrm{pg} / \mathrm{mL} \pm$ $620,02 \mathrm{pg} / \mathrm{mL}$ ) quando comparadas aos controles. (CTHs== 71,85pg/mL $+4,35 \mathrm{pg} / \mathrm{mL})$ e $(\mathrm{CTMs}=$ $741,58 \mathrm{pg} / \mathrm{mL} \pm 570,20 \mathrm{pg} / \mathrm{mL})$, cultivadas isoladamente, exceto pelos grupos $(0-20$ anos=1426, pg $/ \mathrm{mL} \pm$ $1030,6 \mathrm{pg} / \mathrm{mL})$ e $(>61$ anos $=1705,75 \mathrm{pg} / \mathrm{mL} \pm 2275,0 \mathrm{pg} / \mathrm{mL})$ no qual não há diferença significativa quando comparado com os controles. Número amostral = CTHs (04), CTMs (04), e co-cultivos 0-20 (04), 21-40 (04), 41-60 (03) e >61 anos (02). 


\subsection{7- Estratégia de análise do receptor CXCR-4 em CTHs}
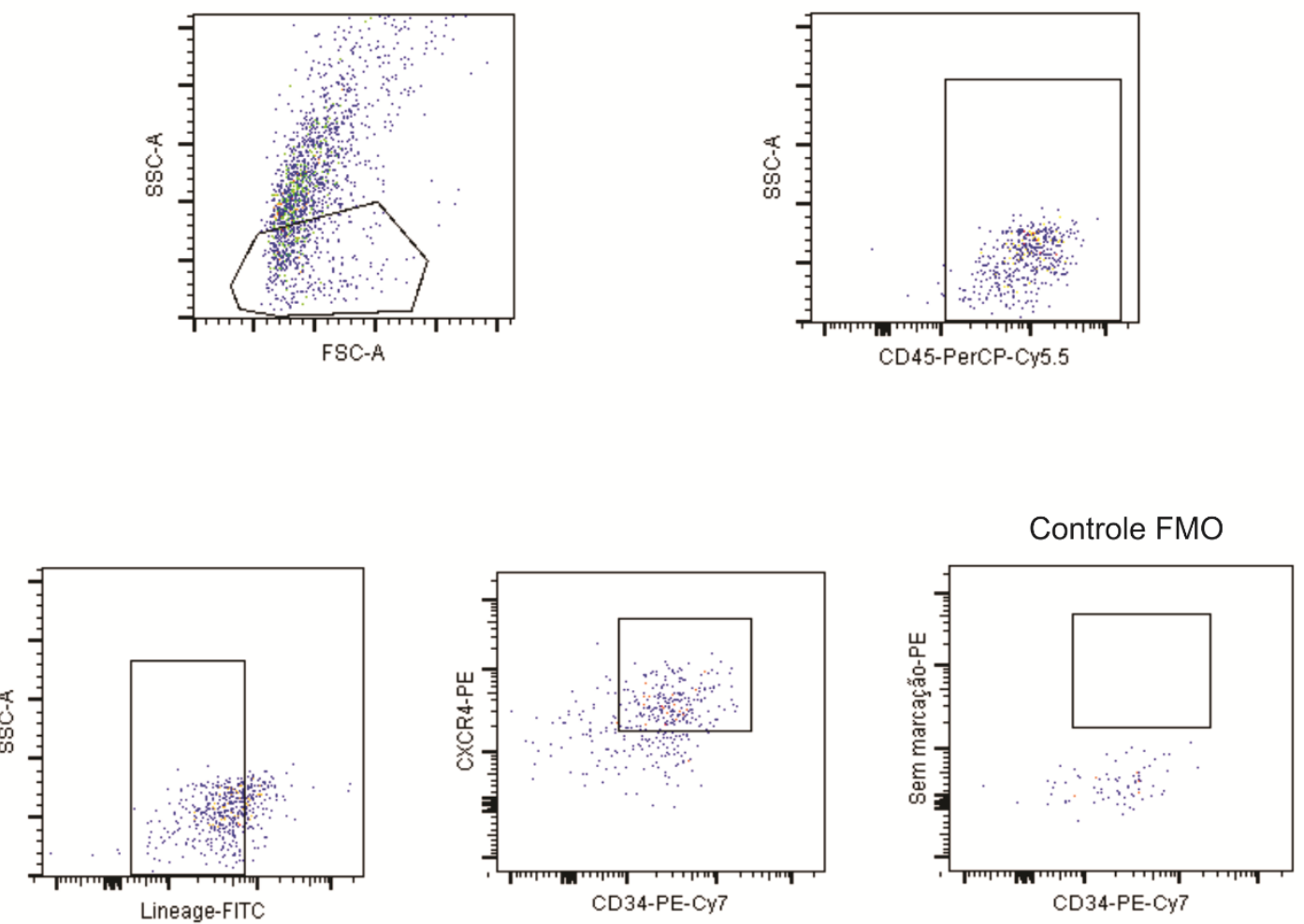

Figura 17 - Estratégia de análise do receptor CXCR4 em CTHs. As células Lin-CD34+ foram quantificadas pelo protocolo ISHAGE. As células foram marcadas com o anticorpo monoclonal anti-CD45 para delimitar a população total de leucócitos e posteriormente a população de células Lin-CD34+ foi caracterizada pela expressão do marcador do receptor CXCR-4.

\subsection{8 - A expressão do CXCR-4 diminui em CTHs de indivíduos idosos.}

Ao analisarmos a expressão do receptor CXCR-4 em CTHs de doadores de medula óssea de diferentes idades, observamos diminuição significativa na expressão do receptor nas CTHs de indivíduos >61 anos. Este resultado sugere que há diferença significativa na expressão do receptor CXCR-4 em CTHs de indivíduos > 61 anos. 


\section{Expressão de CXCR4 nas CTHs}

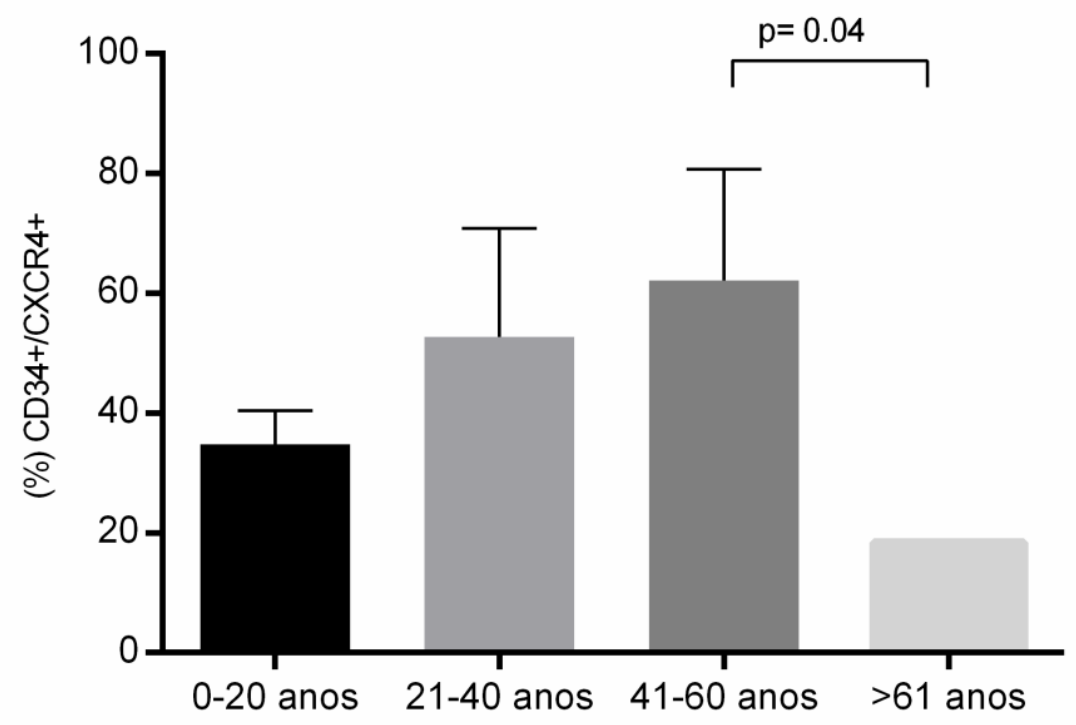

Figura 18 - Expressão de CXCR-4 em CTHs de indivíduos de diferentes idades. A expressão de CXCR-4 em células CD34+ de indivíduos (41-60 anos $=62,18 \% \pm 18,52 \%)$ foi significativamente maior quando comparamos com ( $>61$ anos $=19,2 \% \pm 1,13 \%)$. A expressão de CXCR4 nas células CD34+ dos diferentes grupos $(0-20$ anos $=34,8 \% \pm 5,65 \%), \quad(21-40$ anos $=52,8 \% \pm 18,08 \%), \quad(41-60$ anos $=$ $62,18 \% \pm 18,52 \%)$ e $(>61$ anos $=19,2 \% \pm 1,13 \%)$. Número amostral $=0-20$ anos $(02), 21-40$ anos $(04), 41-$ 60 anos $(04)$ e $>61$ anos (02).

\subsection{9 - Ensaio Clonogênico de CTHs co-cultivadas com CTMs de doadores de diferentes idades}

Foi realizado ensaio clonogênico das CTHs após o co-cultivo com CTMs por três dias para avaliar a funcionalidade destas células. A quantificação e o registro foram realizados por microscopia óptica. 


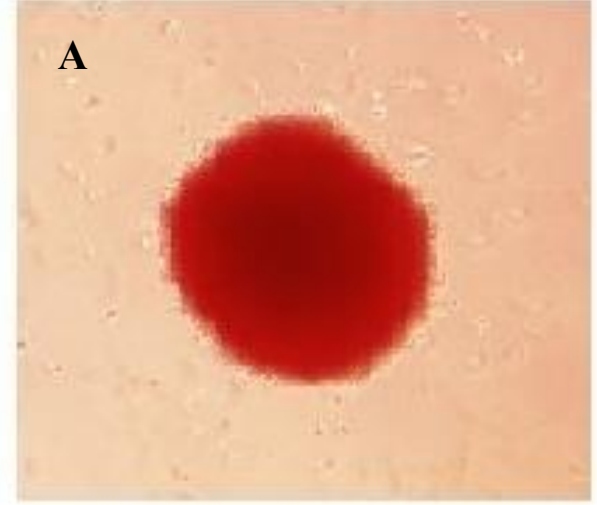

BFU-E

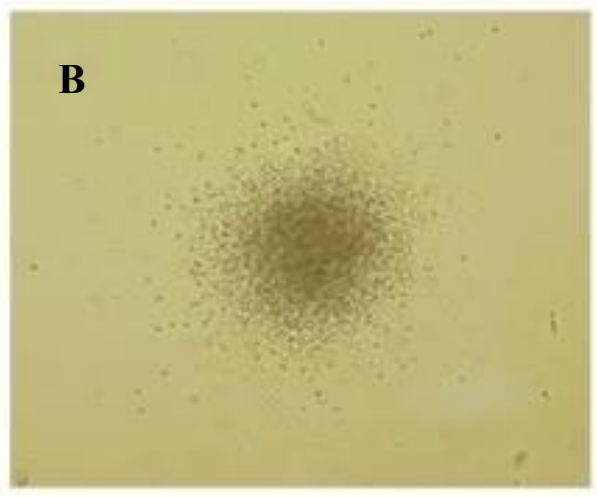

CFU-GM

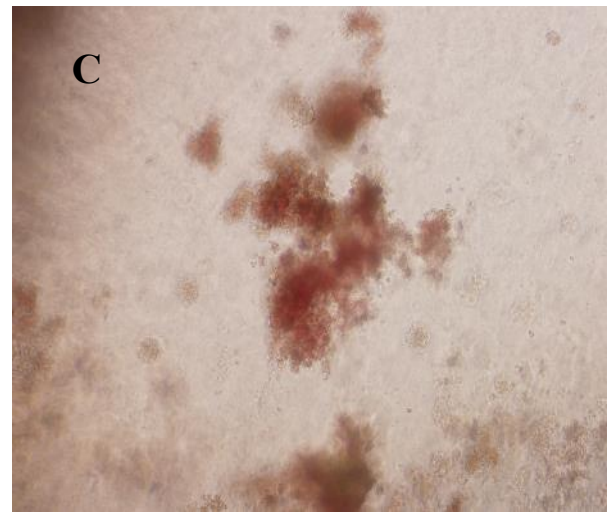

CFU-GEMM

Figura 19- Ensaio clonogênico. Imagens representativas de formação de colônias. (A) Colônia formadora de eritrócitos BFU-E (do inglês, burst forming unit erythroid), (B) colônia formadora de granulócitos e macrófagos CFU-GM (do inglês, colony forming unit granulocyte-macrophage), (D)colônia formadora de eritrócitos, megacariócitos, granulócitos e macrófagos CFU-GEMM (do inglês, colony forming unit granulocyte, erythroid, monocyte/macrophage, megakaryocytes). Aumento de 10x.

\subsubsection{0- CTHs co-cultivadas com CTMs formaram maior número de colônias}

A Figura 20 mostra o número total de colônias mielóides e eritróides formadas por CTHs na ausência (CTRL) e presença de CTMs por três dias. Todas as células tanto o controle quanto as do co-cultivo formaram colônias mostrando que ambas as frações eram funcionais. Porém, notamos que CTHs co-cultivadas com CTMs foram capazes de 
formar mais colônias do que as do controle. Sugerindo que CTHs co-cultivadas com CTMs possuem maior capacidade de diferenciação.

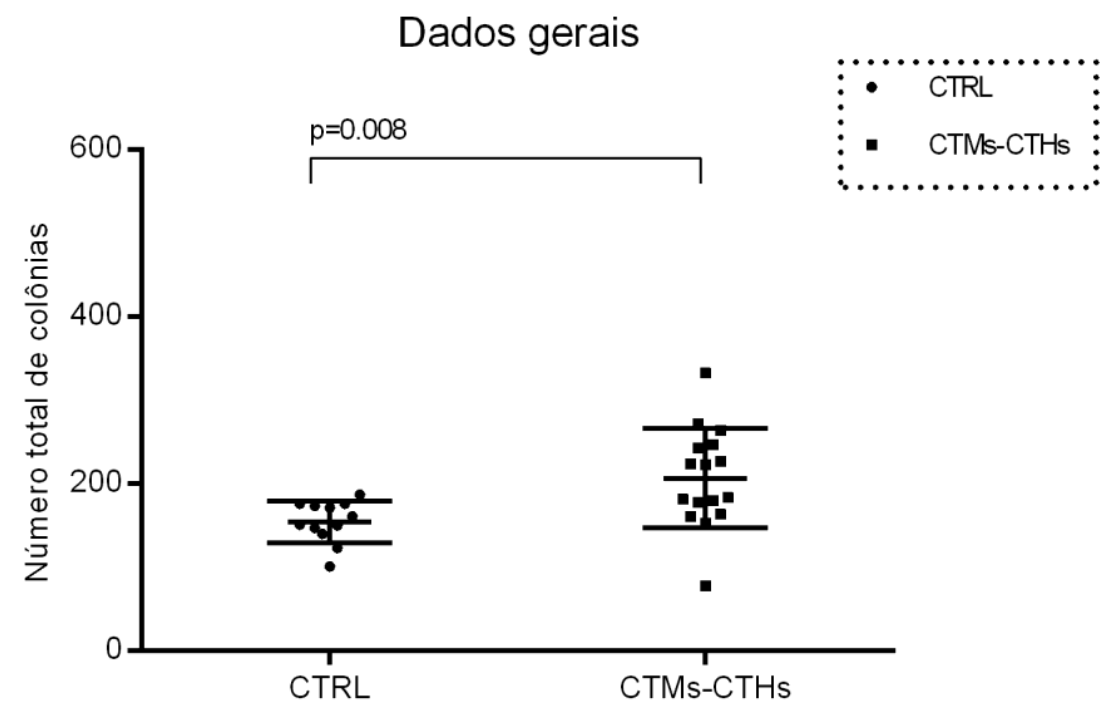

Figura 20 - CTHs co-cultivadas com CTMs apresentaram maior número de colônias. Após 14 dias de cultivo, o número total de colônias foi maior em CTHs co-cultivadas com CTMs. Total de colônias $(\mathrm{CTRL}=154 \pm 24$ colônias e CTMs-CTHs $=206 \pm 59$ colônias). Número amostral CTRL $(\mathrm{n}=12)$ CTHsCTMs $(n=16)$.

\subsubsection{1- CTHs co-cultivadas com CTMs do grupo 0-20 anos formaram mais colônias}

Após o cultivo, o número total de colônias foi quantificado e agrupado de acordo com as idades das CTMs. As células cultivadas com CTMs de doadores de 0-20 anos apresentaram número maior no total de colônias quando comparados ao controle. Indicando maior capacidade funcional destas células. 
Total de colônias por grupos de diferentes idades

(BFU, CFU-GM e CFU-GEMM)

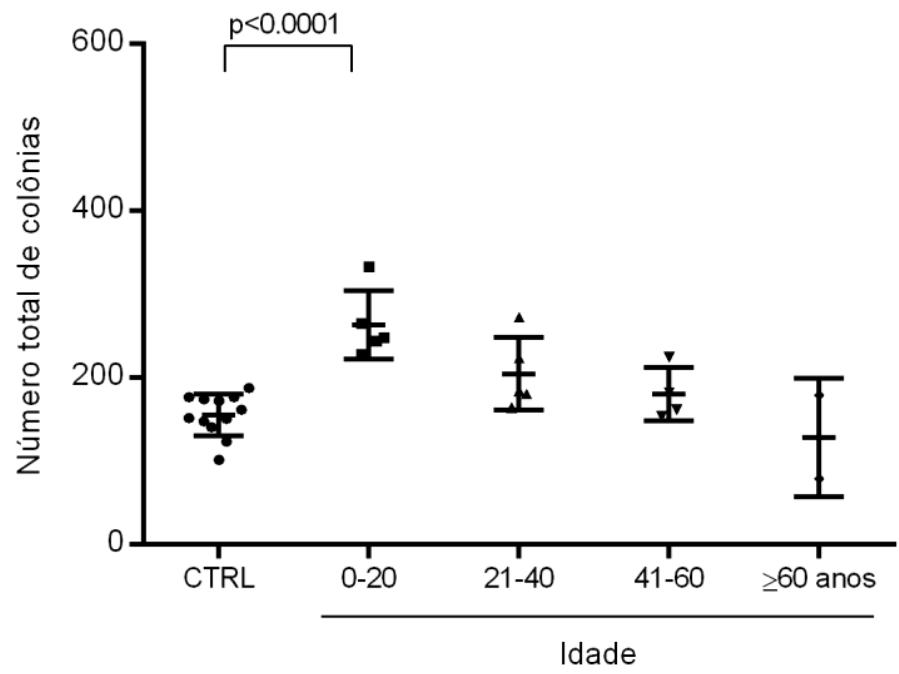

Figura 21 - CTHs co-cultivadas com CTMs do grupo 0-20 anos formaram mais colônias. O número total de colônias foi significativamente maior em CTHs co-cultivadas com CTMs de $(0-20$ anos $=262+41$ colônias), quando comparadas ao controle ( $C T R L=154+24$ colônias), Número total de colônias dos grupos $(\mathrm{CTRL}=154+24$ colônias $),(0-20$ anos $=262+41$ colônias $),(21-40$ anos $=204+43$ colônias $),(41-60$ anos $=179 \pm 31$ colônias $),(>61$ anos $=128+70$ colônias). Número amostral CTRL ( $\mathrm{n}=12)$ 0-20 anos $(\mathrm{n}=05), 21-$ 40 anos $=(\mathrm{n}=05), 41-60$ anos $=(\mathrm{n}=04),>61$ anos $=(\mathrm{n}=02)$. 

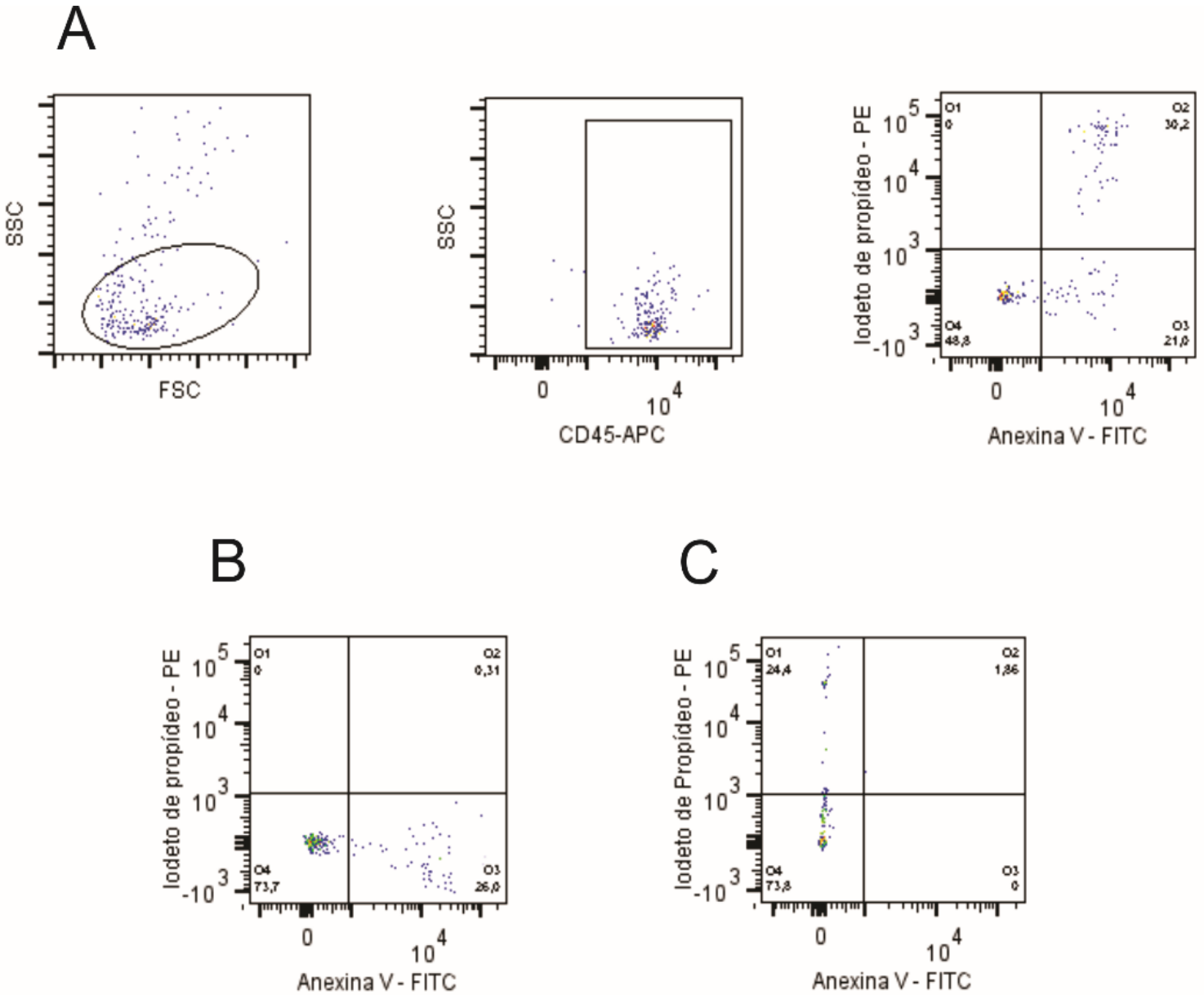

Figura 22- Estratégia de análise de apoptose. Esquema de análise de apoptose em CTH (A) Gate em FSC vs SSC seguido de gate em CD45, e em sequência a análise das percentagens de iodeto de propídeo e anexina-V (B) Controle sem iodeto de propídeo (C) Controle sem Anexina V.

\subsubsection{3- Na análise de apoptose, não foram observadas diferenças significativas} entre as frações $S$ e A quando comparadas ao controle, ou nos co-cultivos com CTMs de diferentes idades.

A Figura 22 (A) mostra a percentagem de morte celular (apoptose inicial/tardia e/ou necrose) das frações $\mathbf{S}$ e $\mathbf{A}$ do co-cultivo com CTHs comparadas ao controle. A Figura 22 (B) mostra a fração $\mathbf{S}$ das CTHs co-cultivadas com CTMs de diferentes idades após sete dias de cultivo. Não houve diferença significativa entre as frações $\mathbf{S}$ 
e A quando comparadas ao controle, e também quando comparamos a fração $\mathrm{S}$ das CTHs co-cultivadas com CTMs de diferentes idades em relação ao controle.
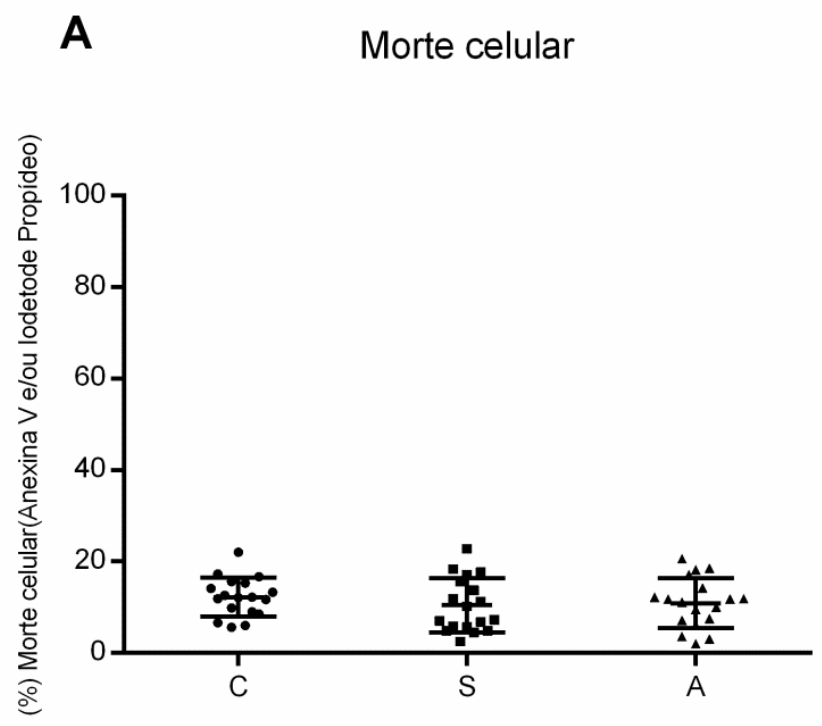

B

(\%) Morte celular nas CTHs co- cultivadas com CTMs de diferentes idades (Fração S)

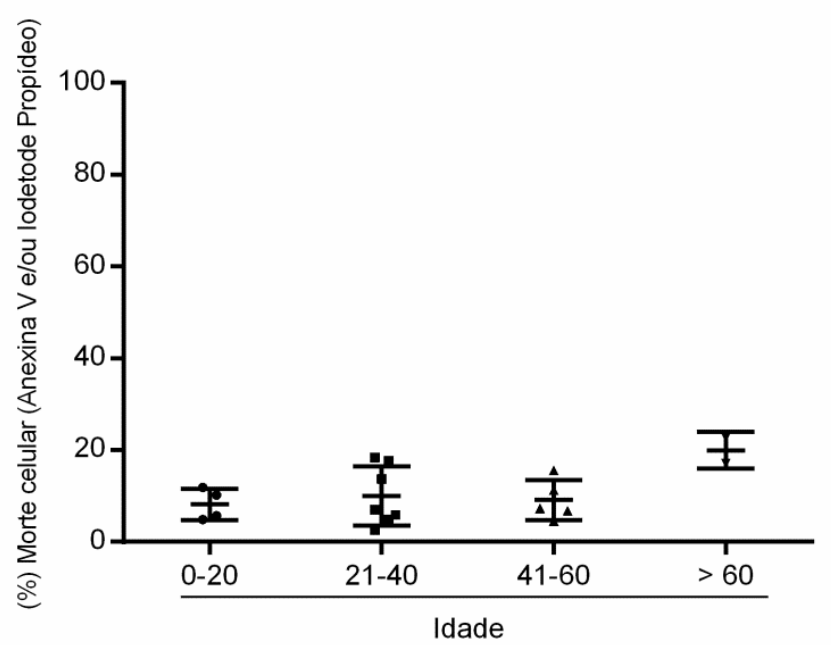

Figura 23- Não houve diferença significativa na morte celular entre as frações A e S comparadas ao controle ou entre as a fração $S$ dos co-cultivos com CTMs de diferentes idades. (A) Não houve diferença significativa na morte celular (apoptose inicial/tardia e/ou necrose) entre as frações $\mathrm{S}=10,4 \% \pm 5 \%$ e $\mathrm{A}=10,8 \% \pm 5 \%$ co-cultivadas com CTMs comparadas ao controle CTRL=12,2\% $\pm 4 \%$. (B) Não houve diferença significativa na morte celular (apoptose inicial/tardia e/ou necrose) nos co-cultivos (Fração S) quando comparamos a idade das CTMs. 


\section{7-DISCUSSÃO}

A medula óssea adulta é formada por um microambiente especializado composto por vários tipos celulares que são responsáveis pela regulação da quiescência, autorrenovação, proliferação e diferenciação de CTHs (16). Várias células parecem participar da manutenção da homeostase do nicho medular, entretanto alguns artigos descrevem a importância do papel de CTMs neste ambiente, seja por interação célulacélula com as CTHs ou pela secreção de fatores solúveis $(121,122)$ Além disso, nos últimos anos, a utilização de CTMs como "camadas alimentadoras" para dar suporte à expansão de CTHs aumentou devido ao seu papel na manutenção da quiescência de CTHs in vivo e in vitro (121). Entretanto, não há relatos na literatura sobre o envelhecimento de CTMs e como este fator pode afetar as CTHs.

Na primeira fase deste estudo, mostramos através de ensaios de caracterização que CTMs humanas de doadores de diferentes idades eram funcionais, e que poderiam ser isoladas a partir da lavagem de filtros reutilizáveis e descartáveis de coleta de medula óssea e, portanto adequadas para serem utilizadas neste estudo (123).

As CTHs foram obtidas de bolsas de sangue de cordão umbilical e caracterizadas por citometria de fluxo utilizando o protocolo ISHAGE. Nestes ensaios observamos que as CTHs estão em diferentes estágios de maturação quando isoladas e por isso as classificamos de acordo com a expressão dos marcadores: Lin ${ }^{-C D} 34^{+} \mathrm{CD} 38^{+} /{ }^{-} \mathrm{CD} 117^{-}$ (células progenitoras primitivas e intermediárias) e $\mathrm{Lin}^{-\mathrm{CD}} 34^{+} \mathrm{CD} 38^{+} /{ }^{-} \mathrm{CD} 117^{+}$(células progenitoras) o que esta de acordo com Oh e colaboradores que descrevem a ontogenia das células CD34+ e CD38- (124).

Através de ensaios de morte celular (apoptose e necrose) e clonogênico mostramos que as células estavam viáveis e funcionais após o isolamento e cultivo, corroborando os primeiros trabalhos publicados pelos bancos de sangue de cordão, os quais mostram que CTHs separadas por gradiente de densidade e criopreservadas continuam funcionais e podem ser utilizadas no transplante de medula óssea $(125,126)$. 
Após a obtenção e caracterização das células iniciamos os ensaios de co-cultivo de CTHs derivadas de SCU (células jovens) com CTMs provenientes de doadores de MO (idades variadas). Observamos nestes co-cultivos, que as CTHs, nos poços de cultura, estão distribuidas em duas regiões distintas, uma parte encontra-se em suspensão no sobrenadante (S) enquanto a outra parte permanece aderida a superfície das CTMs (A) no poço de cultura. As CTHs aderidas às CTMs apresentam fenótipo mais imaturo, sugerindo que a manutenção das CTHs em estado mais indiferenciado é dependente de contato com as CTMs. Além disso, quando em co-cultivo as células tanto (A) quanto (S) mantêm o perfil mais indiferenciado quando comparadas ao controle $(\mathbf{C})$. Estes resultados estão de acordo com os dados reportados nos trabalhos de Alakel e colaboradores, 2008 e Jing e colaboradores, 2010, onde sugerem a influência de fatores solúveis e de contato célula-célula no perfil mais imaturo das CTHs $(122,127)$.

Inicialmente avaliamos a percentagem total de células Lin-CD34+ das frações $\mathbf{S}$ e A nos co-cultivos. Observamos que a percentagem de células com este fenótipo era maior nas CTHS das frações $\mathbf{S}$ e $\mathbf{A}$ no sétimo dia de cultivo quando comparadas ao $\mathbf{C}$. As mesmas foram separadas em grupos de: 0-20, 21-40, 41-60 e >61 anos, e observamos diferenças significativas após sete dias de cultivo nas CTHs da fração (A) quando cultivadas com CTMs dos grupos 0-20, 21-40 and 41-60 anos em relação ao controle. A maior percentagem de células $\operatorname{Lin}^{-} \mathrm{CD} 34^{+}$nesta fração sugere aumento na capacidade da manutenção de um fenótipo indiferenciado das CTHs quando em contato mais íntimo com CTMs, apenas não observamos esta manutenção no grupo >61 anos, sugerindo um efeito da idade que interfere na capacidade das CTMs em manter as CTHs mais próximas e indiferenciadas.

Ao avaliarmos a diferença das subpopulações de células CD34 das CTHs em cultivo com os grupos de CTMs de diferentes idades, a percentagem de células progenitoras primitivas e intermediárias na fração A no grupo 0-20 anos foi maior enquanto a frequência de células progenitoras foi menor quando comparadas ao $\mathbf{C}$. No grupo de 21-40 anos a percentagem de células progenitoras primitivas e intermediárias foi maior tanto na fração $\mathbf{S}$ quanto na $\mathbf{A}$. Já, a percentagem de células progenitoras foi menor nas frações $\mathbf{S}$ e A quando comparadas a $\mathbf{C}$. Estes dados sugerem que CTHs cocultivadas com CTMs derivadas de dois grupos 0-20 e 21-40 apresentam fenótipo mais indiferenciado quando comparadas ao controle, de forma independente de contato. Este 
dado sugere que fatores solúveis também podem estar envolvidos na manutenção de estados mais indiferenciados das CTHs.

Conforme o período de cultivo se ampliou, observamos que a percentagem de células progenitoras primitivas e intermediárias da fração $\mathbf{A}$ foi maior e de progenitoras menor em relação a $\mathbf{C}$, apenas no grupo mais jovem (0-20 anos). Nos grupos 41-60 anos e > 61 anos não foram observadas diferenças significativas. Estes resultados indicam que CTMs jovens possuem maior capacidade em manter CTHs com fenótipos imaturos.

A quimiocina SDF-1, também conhecida como CXCL-12, está presente no nicho e é secretada por células presentes no estroma da MO, dentre elas as CTMs. SDF-1 tem importante papel na retenção $(92,128 z e n g)$, quiescência $(129,130)$, e na atividade de repopulação (131) de CTHs na MO. Sabendo da importância deste fator, avaliamos a secreção desta quimiocina e a expressão do seu receptor CXCR-4.

Para saber se as CTMs de diferentes idades secretam diferentes quantidades de SDF-1, quantificamos esta quimiocina no sobrenadante do terceiro e sétimo dia de cultivo. A síntese proteica de SDF-1 aumenta com a idade, exceto pelo grupo >61anos que apresenta diminuição brusca da secreção desta quimiocina. Ao compararmos a produção de SDF-1 entre os grupos, notamos que a secreção era menor nos grupos 0-20 anos e >61 anos quando comparados ao grupo de 41-60 anos. No sétimo dia, os grupos de 21-40 e 41-60 anos apresentavam maior secreção de SDF-1 quando comparados aos controles, mostrando uma produção crescente nestas faixas etárias. Estes resultados sugerem que o envelhecimento de CTMs pode influenciar a produção de SDF-1 no nicho e, consequentemente levar a alteração nos processos fisiológicos nos quais esta quimiocina está envolvida.

A seguir avaliamos a expressão do receptor CXCR-4 em CTHs autólogas, ou seja, células dos doadores dos quais isolamos as CTMs de diferentes idades. Os dados mostraram que a expressão deste receptor aumenta conforme o indivíduo envelhece exceto pelo grupo >61 anos, o qual apresenta queda brusca desta expressão. Portanto, estes resultados sugerem que a idade do indivíduo influenciou tanto a secreção da SDF-1 pelas CTMs quanto a expressão de CXCR4 pelas CTHs, indicando que o processo de homing na medula óssea pode sofrer desequilíbrio em indivíduos mais idosos, uma vez que a expressão deste receptor está intimamente ligada ao processo de recrutamento de CTHs 
(94). Além do conhecido papel no homing de SDF-1/CXCR4, Ghosh e Kneissel (2009) sugerem uma sinalização cruzada entre a sinalização SDF-1/CXCR-4 e via da WNT (Wnt5a) indicando um possível papel na migração de linfócitos. Entretanto, achamos que esta sinalização cruzada deve ser investigada no contexto da manutenção e autorenovação das células-tronco hematopoeticas no nicho medular $(131,132)$.

As CTHs co-cultivadas com CTMs são funcionais, pois foram capazes de gerar colônias eritróides e mielóides nos ensaios clonogênicos. Observamos que CTHs cocultivadas com CTMs formaram maior número de colônias comparadas aos controles corroborando dados da literatura (133). Quando avaliamos a influência da idade na diferenciação, notamos que CTHs que foram cultivadas com CTMs de doadores mais jovens de 0-20 anos apresentaram um maior número de colônias. Diante destes resultados, podemos sugerir que as CTMs provenientes de microambiente envelhecido podem afetar a função das CTHs no nicho medular. Por fim, avaliamos a morte celular de CTHs das frações $\mathbf{S}$ e $\mathbf{A}$ no sétimo dia de cultivo e não foram observadas diferenças significativas quando comparadas ao controle, sugerindo que as CTMs não afetam a sobrevida "in vitro" deste subtipo celular. 


\section{8-CONCLUSÃO}

As células-tronco mesenquimais foram capazes de manter as células-tronco hematopoéticas em estado indiferenciado e funcionais em condições de co-cultivo, este dado foi mais evidente nos experimentos utilizando células de doadores jovens (0-20 anos) e menos evidente nos experimentos utilizando células de doadores idosos (>61 anos), estas células de indivíduos idosos secretam menos CXCL-12 ao mesmo tempo em que as células-tronco hematopoéticas destes mesmos indivíduos expressam menos o receptor CXCR-4.

Observamos neste trabalho diferenças em parâmetros fenotípicos e funcionais de células-tronco hematopoeticas co-cultivadas com células-tronco mesenquimais de doadores de diferentes idades, e identificamos um possível mecanismo pelo qual o envelhecimento das células estromais pode afetar a homeostase do microambiente medular. 


\title{
9- ANEXOS
}

\section{1- Parecer - Certificado de apresentação para apreciação ética}

\author{
FACULDADE DE MEDICINA DA \\ UNIVERSIDADE DE SÃO \\ PAULO - FMUSP
}

\section{PARECER CONSUBSTANCIADO DO CEP}

Elaborado pela Instituição Coparticipante

\section{DADOS DO PROJETO DE PESQUISA}

Título da Pesquisa: Potencial influência do envelhecimento das células-tronco mesenquimais na autorenovação, diferenciação e multipotência de células-tronco hematopoéticas.

Pesquisador: Luciana Cavalheiro Marti

Área Temática:

Versão: 3

CAAE: 21840113.0 .0000 .0071

Instituição Proponente:Hospital Israelita Albert Einstein-SP

Patrocinador Principal: Hospital Israelita Albert Einstein-SP

\section{DADOS DO PARECER}

Número do Parecer: 523.747

Data da Relatoria: 05/02/2014

Apresentação do Projeto:

Trata-se de adequação de TCLE de projeto já avaliado e cuja única recomendação era a modificação do TCLE para incluir possibilidade de indenização

Objetivo da Pesquisa:

Avaliar a influencia da idade do doadro de células tronco mesenquimais no resultado de seu uso.

Avaliação dos Riscos e Benefícios:

Sem riscos e com beneficios cientificos e operacionais para o TMO

Comentários e Considerações sobre a Pesquisa:

Correção do TCLE necessária

Considerações sobre os Termos de apresentação obrigatória:

TCLE corrigido

Recomendações:

Uso do TCLE corrigido e exclusão do arquivo do TCLE deficiente

Conclusões ou Pendências e Lista de Inadequações:

Sem pendencias

Endereço: DOUTOR ARNALDO 455

Bairro: PACAEMBU

UF: SP Municipio: SAO PAULO

CEP: $\quad 01.246-903$

Telefonè: (11)3061-8004

E-mail: cep.fm@usp.br 


\section{FACULDADE DE MEDICINA DA UNIVERSIDADE DE SÃO PAULO - FMUSP}

Continuaçวo do Parecer: 523.74

Situação do Parecer:

Aprovado

Necessita Apreciação da CONEP:

Não

Consideraçōes Finais a critério do CEP:

Aprovado

SAO PAULO, 07 de Fevereiro de 2014

Assinador por:

Roger Chammas

(Coordenador)

Endereço: DOUTOR ARNALDO 455

Bairro: PACAEMBU

UF: SP Municipio: SAO PAULO

CEP: $01.246-903$

Telefone: (11)3061-8004

E-mail: cep.fm@usp.br 


\title{
9.2- Termo de ciência do comitê de ética em pesquisa
}

\author{
4.1 1.1 \\ MEDICINA \\ COMITÊ DE ÉTICA EM PESQUISA
}

\section{CIÊNCIA}

O Comitê de Ética em Pesquisa da Faculdade de Medicina da Universidade de São Paulo, em 17.02.14 tomou ciência do Projeto $n^{0}$ o19/14 intitulado "Potencial influência do envelhecimento das células-tronco mesenquimais na autorenovação, diferenciação e multipotência de células-tronco hematopoéticas.", vinculado à pós-graduação do Departamento de Clínica Médica, que não envolverá atividade prática e/ou experimental no âmbito da Faculdade de Medicina ou Instituto do Câncer do Estado de São Paulo e que conta com prévia aprovação do Comitê de Ética em Pesquisa do Hospital Israelita Albert Einstein.

Pesquisador(a) Responsável: Luciana Cavalheiro Marti

Pesquisador(a) Executante : Suzana da Silva Benedito

CEP-FMUSP, 17 de fevereiro de 2014

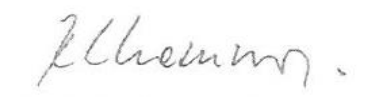

Prof. Dr.Roger Chammas Coordenador

Comitê de Ética em Pesquisa

Comitè de Ética em Pesquisa

Faculdade de Medicina da Universidade de São Paulo 


\section{3 - Artigo submetido}

American Journal of Hematology

Stromal cells aging and the impact in hematopoietic stem cells differentiation and self-renew

\begin{tabular}{|r|l|}
\hline Journal: & American Joumal of Hematoloqy \\
\hline Manuscript ID & Draft \\
\hline Date Submitted by the Author: & Research Article \\
\hline Complete List of Authors: & $\begin{array}{l}\text { Benedito, Suzana; Hospital Israelita Albert Einstein, Experimental } \\
\text { Research; Universidade de Sao Paulo Faculdade de Medicina, Programa de } \\
\text { Pós-graduação em Alergia e Imunopatologia } \\
\text { Almeida, Camila; Hospital Israelita Albert Einstein } \\
\text { Rocha, Fernanda; Hospital Israelita Albert Einstein, Experimental Research } \\
\text { Kutner, Jose; Hospital Israelita Albert Einstein, Blood Bank } \\
\text { Kondo, Andrea; Hospital Israelita Albert Einstein, Blood Bank } \\
\text { Marti, Luciana; Hospital Israelita Albert Einstein, Experimental Research; } \\
\text { Universidade de Sao Paulo Faculdade de Medicina, Programa de Pós- } \\
\text { qraduação em Alerqia e Imunopatoloqia }\end{array}$ \\
\hline Keywords: & $\begin{array}{l}\text { Stroma cells, Hematopoiesis- stem and primitive progenitor cells, Bone } \\
\text { marrow niche }\end{array}$ \\
\hline
\end{tabular}

SCHOLARONE

Manuscripts 
1

2

3

4

5

6

7

8

9

Stromal cells aging and the impact in hematopoietic stem cells

\section{differentiation and self-renew}

Benedito $\mathrm{S}^{1,3}$, Almeida $\mathrm{CB}^{1}$, Rocha $\mathrm{FA}^{1}$, Kutner $\mathrm{JM}^{2}$, Kondo $\mathrm{A}^{2}$, Marti $\mathrm{L}^{1,3}$.

1- Hospital Israelita Albert Einstein - Experimental Research Department - São Paulo - Brazil

2- Hospital Israelita Albert Einstein - Blood Bank Department - São Paulo - Brazil

3- Programa de Pós-graduaçào em Alergia e Imunopatologia - Faculdade de Medicina da Universidade de Sào Paulo (FMUSP).

Corresponding author:

Luciana Cavalheiro Marti, $\mathrm{PhD}$

Email: luciana.marti@einstein br, Phone: +55 1121511353

Adress:

Hospital Israelita Albert Einstein

Experimental Research Department

Av. Albert Einstein, 627, Bloco A, $2^{\circ} \mathrm{SS}$

Morumbi - São Paulo - SP - Brazil

Zip code: 05652000 


\begin{abstract}
Certainly, aging is one of the best identified features of the human biology, and is also the least understood. This is largely attributed to the fact that aging is gradual and fundamentally complex, due to all modifications in the physiological and phenotypic aspects. One of the most striking features of aging is the decreased ability to maintain homeostasis and tissue repair. Consistent with those findings, many of the pathophysiological conditions affecting aging, such as anemia, dysplasia, leukemia and anemia suggest an imbalance between cell losses and the ability to self-renew or differentiation. Increasing evidences point to the stem cells as major accountable for the aging pathophysiology in several tissues. The hematopoietic stem cell microenvironment is located in the bone marrow and is divided in two domains: the endosteal niche near to bone surface and vascular niche associated with the sinusoidal endothelium; the niche consist of several heterogeneous cells types, among them, are mesenchymal stem cells. These cells express molecules that control hematopoietic stem cells functions. Therefore, this study investigates the role of mesenchymal stem cells aging in the self-renewal, multipotency and differentiation of hematopoietic stem cells. This study evaluated percentage of hematopoietic stem cell $\mathrm{Lin}^{-} \mathrm{CD} 34^{+}$and their subpopulations in co-culture with mesenchymal stem cell bone marrow-derived from donors with different ages, their ability of self-renewal, differentiation, secretion of CXCL-12 chemokine and expression of the CXCR-4 receptor. Our results suggest that the mesenchymal stem cells aging can affect bone marrow niche homeostasis.
\end{abstract}




\section{INTRODUCTION}

Certainly, aging is one of the most identified features of the human biology, and is also the less understood. This is largely attributed to the fact that aging is gradual and fundamentally complex, due to all the modifications in the physiological and phenotypic aspects.

One of the most striking features of aging is the decreased ability to maintain homeostasis and tissue repair. The increasing age is accompanied by many pathophysiological changes in hematopoietic system wherein the etiology suggests loss of homeostatic control and a possible involvement of stem and progenitor cells. The clinically relevant changes are related to diminished competence of adaptive immune system [1], increased myeloid diseases including leukemia [2] and the onset of anemia in the elderly [3].

Hematopoietic stem cells (HSCs) have ability of self-renew and derive all blood cells types [4]. HSCs ability to derive progenitor cells decreases substantially during the ontological transition from the fetal liver to the adult bone marrow [5], suggesting a progressive loss of their potential for self-renewal and differentiation with advancing age.

HSCs and hematopoietic progenitors are located inside bone marrow microenvironment known as niches, which provide the regulatory signals for maintenance, proliferation and differentiation of these cells.

Since 1970 mumerous studies have been conducted in order to elucidate the role and the cellular and molecular components of niche. The concept of stem cell niche has been proposed by Schofield in 1978; when carrying out cells derived from bone marrow or spleen into irradiated mice, they observed that bone marrow cells were more efficient than spleen cells in hematopoietic reconstitution. These results suggested that bone marrow cells have hematopoietic reconstitution ability preserved and then considered the microenvironment of these cells [6].

Later, other studies have suggested that bone marrow are divided into two niches types throughout development responsible for $\mathrm{HSC}$ s maintaining which are mainly regulated by intrinsic factors in a complex network of molecules signaling and growth factors. These niches are distributed in a special architecture inside bone marrow, where $\mathrm{HSC}$ s can be found in the endosteal region (osteoblastic niche) or close to the sinusoidal 
endothelium (perivascular niche). Oh and Kwon have demonstrated the existence of these two niches with distinct functions and cellular interactions [7]. Niches are complex and comprise a wide variety of cells including bone lineage (osteoblasts and osteoclasts), mesenchymal stem cells (mesenchymal stromal cells), sinusoidal endothelial cells, perivascular stromal cells, and other immune cells which play different roles in the $\mathrm{HSC}$ s regulation $[7,8]$.

Endosteal niche is located at bone marrow cavity surface which is composed by cortical and trabecular bone, and their surface is composed by osteoblasts and osteoclasts. [9]. HSCs are located mainly adjacent to sinusoidal vessels throughout the bone marrow [10-13], where endothelial and mesenchymal cells promote their maintenance by the production of stem cell factor [14], CXCL-12 chemokine [13-15] and probably other factors.

Others cells may also promote the HSCs maintenance around other blood vessels such as arterioles. The perivascular stromal cells, such as cells CAR (CXCL-12 abundant reticular cells) [13], are compromised to the bone formation [16]. Other cells types can also participate in the niche regulation, as the sympathetic nerve $[17,18]$, nonmyelinating Schwann cells, which are also nestin positive [19], macrophages [20] and osteoclasts [21]. Osteoblasts may promote the maintenance and differentiation of some lymphoid progenitors by secreting CXCL-12 and other factors [22-25].

The bone marrow microenvironment changes substantially with aging. Differences in cellular composition of $\mathrm{HSC}$ niche during aging were observed in haematopoietic system [26]. Previous studies conducted with rats showed that mesenchymal stem cells are able to regulate $\mathrm{HSC}$ s niche and aging consequences are related to mesenchymal stem cells $\mathrm{CD} 90^{+} \mathrm{CD} 105^{+}$decline [27]. Stolzing et al showed in humans that a major difference in numbers of fibroblast colonies units formation (CFU-F) occur between an adolescent group (age below 20) and adult group (age above 20), finding a decline in the CFU-F number with aging $[28,29]$. However, yet consensus has not been reached as to whether MSC change niche functions with age in mice and humans [30].

Therefore, our hypothesis is that mesenchymal stem cells aging can affect the niche homeostasis by interfering with $\mathrm{HSC}$ maintenance, self-renewal, multipotency and differentiation processes. 
Our study showed that different ages donors derived mesenchymal stem cell were able to keep HSCs under undifferentiated and functional states, this data was more evident in experiments using cells from younger donors ( $0-20$ years) and less obvious in experiments using cells from elderly donors $(>61$ years). We observed that elderly individual cells secrete less CXCL-12 at the same time HSCs from the same individuals express least CXCR-4 receptor. Differences were observed in phenotypic and functional parameters of HSCs co-cultured with mesenchymal stem cells from donors of different ages, and we were able to identify a possible role by which stromal cells aging may affect the homeostasis of bone marrow microenvironment.

\section{MATERIAL AND METHOD}

\section{Cells}

Mesenchymal stem cells (MSC) were obtained from healthy bone marrow donors by washing the cells trapped in the dischargeable collection filter as previously described by Deus et al. [31]. Umbilical cord blood (UCB) samples were obtained from rejected low volume/cellularity units of umbilical cord blood donation from public bank following informed consent signing. This project was approved by Ethical Committees from Hospital Israelita Albert Einstein and Faculdade da Medicine da Universidade de São Paulo - USP, under CAAE number: 21840113.0.0000.0071.

MSC were isolated from 19 individuals and they were grouped by age as: $0-20$ years old (6 samples), 21-40 years old ( 5 samples), 41-60 years old ( 5 samples), and $>61$ years old (3 samples). Twenty UCB samples were collected and HSC was isolated by ficoll and frozen for further experiments.

Briefly, umbilical cord blood cells were diluted 1:3 (vol/vol) with Phosphate Buffered Saline (PBS). Next, this suspension was transferred to a $50 \mathrm{~mL}$ conical tube containing $20 \mathrm{~mL}$ of Ficoll-Paque 1.077 density (GE Healthcare, United Kingdom) and centrifuged $\left(30 \mathrm{~min} / 500 \mathrm{~g}\right.$ ) at $22^{\circ} \mathrm{C}$. Then, the cells from the interface were collected, ressuspended and centrifuged again $(5 \mathrm{~min} / 500 \mathrm{~g})$. The supernatant was discarded and cells ressuspended with freezing media (DMEM-LG, supplemented with $40 \% \mathrm{FBS}, 10 \%$ DMSO, $1 \%$ antibiotic-antimycotic and $2 \mathrm{mM} \mathrm{L}$-glutamine) and frozen at the concentration of $1 \times 10^{6}$ cells $/ \mathrm{mL}$, for the further experiments. 
Bone marrow collection filters were washed with $20 \mathrm{~mL}$ DMEM-LG and diluted 1:3 ( $\mathrm{rol} / \mathrm{vol}$ ) with Phosphate Buffered Saline (PBS). Next, this suspension was transferred to a $50 \mathrm{~mL}$ conical tube containing $20 \mathrm{~mL}$ of Ficoll-Paque 1.077 density (GE Healthcare, United Kingdom) and centrifuged $(30 \mathrm{~min} / 500 \mathrm{~g})$ at $22^{\circ} \mathrm{C}$. Cells from interface were collected, ressuspended and centrifuged again $(5 \mathrm{~min} / 500 \mathrm{~g})$. Supematant was discarded and cells were ressuspended with DMEM-LG, supplemented with 10\% FBS, $1 \%$ antibiotic-antimycotic, $2 \mathrm{mM}$ L-glutamine, in order to achieve $1 \times 10^{5}$ cells $/ \mathrm{mL}$. DMEM-LG, supplements and PBS were acquired by Gibco (Carlsbad, CA). Next, cells $\left(5 \mathrm{~mL}\right.$ ) were cultivated into $25 \mathrm{~cm}^{2}$ flasks for 48 hours and maintained in humidified $5 \%$ $\mathrm{CO}_{2}$ incubators at $37^{\circ} \mathrm{C}$ to favor the attachment of the MSCs to the flask bottom. Nonadherent cells were discarded; adherent layer was washed twice with DMEM-LG and maintained in culture until the $4^{\text {th }}$ passage.

Mesenchymal stem cell characterization by flow cytometric expression markers Cells from passage four were used to analysis of cell surface markers according previous described by Normanton et al [32]. Cells were washed with PBS, and then detached from plastic surface with TryPLE (Gibco Carlsbad, CA). Next, cells were stained for CD106-FITC (clone: 51-10C9), CD73-PE (clone: AD2), CD34-PE (clone: My10), CD105-PE-CF594 (clone: 266), CD90-PE-Cy7 (clone: SE10), CD29-APC (clone: MAR04), CD14-Alexa 700 (clone: M5E2) from BD Pharmingen (San DiegoCA), CD44-PerCPCy5 (clone: G44-26), HLA-DR-APC-H7 (clone: G46-6) from Biosciences (San Jose - CA), CD45-V500 (clone: H130) and CD31-V450 (clone: WM59) from Biolegend (San Diego-CA), and for fluorescence minus one (FMO). After staining, cells were incubated at room temperature for 30 minutes, followed by a wash step; cells were ressuspended and measurements were performed using FACSARIA equipment (BD Biosciences).

\section{Mesenchymal stem cell characterization by adipocyte, chondrocyte and osteocyte} differentiation

After establishment of hMSCs cultures on the fourth passage, cells were differentiated into adipocytes, osteoblasts, and chondrocytes. Adipogenesis was induced by addition of an adipogenic medium to hMSCs culture, this medium was comprised by AlphaMEM supplemented with $10 \%$ FBS, $1 \mu \mathrm{m}$ dexamethasone, $100 \mu \mathrm{g} / \mathrm{mL}$ 3-Isobutyl-1methylxanthine, $10 \mu \mathrm{g} / \mathrm{mL}$ insulin and $100 \mu \mathrm{M}$ indomethacin. Adipogenic medium was 
changed every other day for 3 weeks. After 3 cells were fixed in $4 \%$ paraformaldehyde for 30 minutes, washed, dehydrated in $60 \%$ isopropanol for 2 to 5 minutes, and stained with $0.5 \%$ Oil Red O in $100 \%$ isopropanol previously diluted in water to evidence lipid droplets formation.

Osteogenesis was induced by addition of an osteogenic medium (Alpha-MEM supplemented with $10 \% \mathrm{FBS}, 1 \mu \mathrm{m}$ dexamethasone, $2 \mu \mathrm{g} / \mathrm{mL}$ ascorbic acid and $10 \mu \mathrm{m}$ $\beta$-glycerophosphate) and chondrogenesis was induced by addition of a chondrogenic medium (Alpha-MEM supplemented with 10\% FBS, $1 \mu \mathrm{m}$ dexamethasone, $2 \mu \mathrm{g} / \mathrm{mL}$ ascorbic acid, $6,25 \mu \mathrm{g} / \mathrm{mL}$ insulin, and $10 \mathrm{ng} / \mathrm{mL}$ TGF- $\beta$ ). Next steps were similar to adipogenisis procedure except by stained, that was with Alizarin Red ( $2 \mathrm{~g}$ in $100 \mathrm{~mL}$ of distillated water) $\mathrm{pH} 4.2$ to evidence the calcium deposition in osteogenic marker and toluidine blue to evidence the proteoglycans enriched matrix in condrocytes.

The mentioned culture medium and FBS were purchased from Gibco (Carlsbad, CA) and all other reagents were from Sigma (St Louis, MO).

\section{Umbilical cord blood hematopoietic stem cell isolation}

Umbilical cord blood cells were defrosted in thawing media (DMEM-LG, supplemented with $40 \% \mathrm{FBS}, 1 \%$ antibiotic-antimycotic and $2 \mathrm{mM} \mathrm{L}$-glutamine). Next, cells were centrifuged $(5 \mathrm{~min} / 500 \mathrm{~g})$ at $22^{\circ} \mathrm{C}$, pellet cells was diluted in culture media and transferred to tube containing $5 \mathrm{~mL}$ of Ficoll-Paque 1.077 density and centrifuged (30 $\min / 500 \mathrm{~g}$ ) at $22^{\circ} \mathrm{C}$. Then, cells from interface were collected, ressuspended and centrifuged again $(5 \mathrm{~min} / 500 \mathrm{~g})$ at $22^{\circ} \mathrm{C}$. Supematant was discarded and cells ressuspended in DMEM-LG, supplemented with $10 \%$ FBS, $1 \%$ antibiotic-antimycotic and $2 \mathrm{mM} \mathrm{L}$-glutamine. Cells were evaluated for the viability using Trypan blue solution $0.4 \%$ (Gibco), and only samples over $90 \%$ viability were used for hematopoietic stem cells selection.

Hematopoietic stem cells derived from umbilical cord blood $(C D 34+)$ were separated by direct cell targeting using CD34 Microbead Kit human isolation Kit II (Miltenyi biotec) according manufactures instruction. However, to increase cells purity we have used two columns to select cells. Number and viability of isolated CD34+ cell were determined by manual counting with trypan blue solution and by flow cytometry. 
Hematopoietic stem cell characterization and viability by flow cytometric analysis After $\mathrm{CD} 34+$ isolation, they were used to analyse surface markers using the International Society for Hematotherapy and Graft Engineering - ISHAGE protocol recommendation [33]. Cells were stained for Lineage-FITC, CD34-PE-Cy7 (clone: 8G12), CD117-APC (clone: 104D2) and CXCR4-PE (clone: 12G5) (BD Pharmingen, San Diego, CA), CD38-PE (clone: T16) and CD45 PerCP-Cy5.5 (clone: J33) (Beckman Coulter, Marseille, France).

To analysis viability/cell death was used a combination of CD45-APC (clone: J33) (Beckman Coulter, Marseille, France), Annexin-V-FITC and Propidium iodide (BD Pharmingen, San Diego, CA).

Corresponding isotype controls were used as control and/or for fluorescence minus one (FMO) for both staining protocol. After staining, cells were incubated at room temperature for 30 minutes, followed by a wash step or for viability/cell death addition of $400 \mu 1$ de Annexin-V binding buffer (BD Biosciences, San Jose, CA); cells were ressuspended and measurements were performed using FACSARIA equipment (BD Biosciences).

\section{Culture of hematopoietic stem cells}

Hematopoietic stem cells were culture at density of $1 \times 10^{4}$ cells per well (24 well plate) with StemSpan H3000 (Stem Cell Technologies, Vancouver, Canada) supplemented with minimal concentration of stem cell factor (SCF) $5 \mathrm{ng} / \mathrm{ml}$, interleukin 6 (ㄴ-6) $5 \mathrm{ng} / \mathrm{ml}$, interleukin 3 (ㅍ- -3) $5 \mathrm{ng} / \mathrm{ml}$ and tyrosine kinase-3 ligand (Flt3-L) 6,2ng/ml (all factors were purchased from $R \& D$ Systems, Minneapolis, MN) to avoid cell death.

HSCs were cultured alone (control) or together with MSCs previous plated at concentration of $2 \times 10^{4}$ cells/well. Phenotypic analysis was performed on days 0,3 and 7 in the HSCs co-cultures with MSCs or alone (control). Viability/cell death analysis was fulfilled only on day 0 and 7 .

\section{Harvest of hematopoietic stem cells from mesenchymal stem cells co-cultures}

Non-adherent $\mathrm{HSCs}$ in culture were harvested from supernatant on days 3 and 7 and were designated as cells from " $\mathrm{S}$ " fraction. However, there were remaining HSCs adhered to MSCs, for this cells removal was necessary to use trypsin, following a CD45 selection, separated by direct cell targeting using CD45 Microbead Kit human isolation 
Kit (Miltenyi biotec) according manufactures instructions, in order to deplete MSCs and capture the whole hematopoietic cells that remained in culture.

\section{Clonogenic assay}

Clonogenic assays were performed to evaluate HSCs and progenitors capacity to generate colonies on days 0 and 3 . HSCs alone (control) or after co-culture with MSCs were inoculated at a concentration of $1 \times 10^{3}$ to $1 \mathrm{~mL}$ of Methocult H4434 (Stem Cell Technologies, Vancouver, Canada) in a well of a 6 well plate. These assays were incubated for 14 days in humidified $\mathrm{CO}_{2}$ incubator and analyzed for colonies formation of BFU-E (erythroid colony), CFU-GM (granulocytes and macrophages colonies) and CFU-GEMM (mixed).

\section{ELISA}

Chemokine CXCL-12/SDF-1 was measured in supernatant of HSCs cultures (control) and in the MSCs co-cultures. A quantitative analysis was perfermed using Human CXCL12/SDF-1 alpha Quantiline ELISA Kit from R\&D Systems, following the manufactors recommendations. Plate readings were carried out using microplate reader SpectraMax is (Molecular Devices, Sunnyvale, CA). Readings were performed at $450 \mathrm{~nm} / 540 \mathrm{~nm}$ and the standard curve was set at 4 parameters logistic or $\log \log$ curve fit, according to each manufacturer's protocols.

\section{Statistics analysis}

GraphPad Prisma Program (GraphPad Software, San Diego, CA) was used to perform the statistical analyses. Statistical significance was calculated by Student's $t$-test or ANOVA with Bonferroni correction for multiple comparisons; $p<0.05$ was considered significant. 


\title{
RESULTS
}

\section{Mesenchymal stem cells characterization}

Human mesenchymal stem cells used in our assays completely fulfilled the identity criteria established by the International Society for Cell Therapy (ISCT), as shown by Figure 1A-D.

\begin{abstract}
Mesenchymal stem cells aging can diminish their ability to mantain hematopoietic stem cells in culture for extended periods preserving Lin-CD34+ phenotype.

Hematopoietic stem cells were characterized using the International Society of Hematotherapy and Graft Engineering (ISHAGE) protocol and the gate strategy is shown in Figure 2A. First, our analysis were performed for total CD34 population (LinCD34+). HSCs were categorized according their localization in culture well, cells suspensed in the supematant were called S fraction, and those adhered to MSCs were called A. Cells cultured in absence of MSCs were called C (control), as detailed in
\end{abstract} Figure 2B.

A total of 19 different MSCs were co-cultured with umbilical cord blood HSCs which were tested for expression of lineage and CD34 and we observe after 3 days in culture that the percentages of $\mathrm{Lin}-\mathrm{CD} 34+$ was $91.87 \pm 10.90 \%$ for $\mathrm{C}, 87.83 \pm 10.58 \%$ for $\mathrm{S}$ and $80.32 \pm 18.05 \%$ for $\mathrm{A}$, without significative differences among groups. However, when we analysed the same conditions after 7 days in culture, we observed a intense decrease of Lin-CD34+ population in C $(49.37 \pm 11.72 \%)$, but not in S $(69.42 \pm 13.94 \%)$ or A $(75.74 \pm 13.11 \%)$, with significance difference between control and $\mathrm{HSC}$ s co-cultured fractions $\mathrm{S}$ and $\mathrm{A}$, as shown in Figure $2 \mathrm{C}$. This data suggest an ability of MSCs to mantain hematopoietic stem cells in culture for extended periods, preserving LinCD34+ phenotype.

Experiments were grouped by MSCs age donor and we observed no significative difference in HSCs after 3 days in culture for Lin-CD34+ population comparing fractions $\mathrm{S}$ and $\mathrm{A}$ to $\mathrm{C}$. However, after 7 days in culture we observed significative differences for $\mathrm{Lin}-\mathrm{CD} 34+$ population between $\mathrm{C}$ and co-cultured fractions $\mathrm{S}$ and $\mathrm{A}$ for 0-20, 21-40 and 41-60 years groups (Figure 2D-E). 
These results suggest a possible impaired ability of aged $\mathrm{MSC}$ s to mantain hematopoietic stem cells in culture for extended periods preserving Lin-CD34+ phenotype.

Mesenchymal stem cells aging can diminish their ability to mantain hematopoietic stem cells in culture preserving Lin-CD34+CD38+/-CD117- subpopulations

Stem cells are known for their self-renewal capacity, while hematopoietic progenitor may be committed to myeloid lineage, thus, they are more differentiated cells. In order to identify the stem cells subpopulations we use in addition to Lineage and CD34, other markers CD38 and CD117. Stem cells were characterized by absence of CD117 while progenitors were identified by expression of CD117 and the gate strategy was shown in Figure $3 \mathrm{~A}$

Generally, after 3 days in culture we were able to observe that stem cells percentages were increased in co-cultures compared to control as seem by C $31.1 \pm 15 \%, \mathrm{~S}$ $50.17 \pm 19 \%$ and $A 66.33 \pm 24 \%$, showing significant differences among conditions. On the other hand, progenitor cells percentage were lower in co-cultures compared to control, as shown by $\mathrm{C} 68.92 \pm 15 \%, \mathrm{~S} 51.77 \pm 18 \%$ and $\mathrm{A} 37.74 \pm 25 \%$, showing significant differences among conditions as shown in Figure 3B. Further, after 7 days in culture we observed that stem cells percentages werehigher in co-cultures compared to control as seem by $\mathrm{C} 58.595 \pm 11 \%, \mathrm{~S} 61.79+17 \%$ and $\mathrm{A} 68.85 \pm 21 \%$, while progenitors cells percentages were for $\mathrm{C} 40.67 \pm 11 \%, \mathrm{~S} 38.19 \pm 17 \%$ and $\mathrm{A} 30.93 \pm 21 \%$, showing higher percentage of differentiated cells in absence of MSCs, as shown in Figure $3 \mathrm{C}$. These results suggest that MSCs are able to maintain HSCs undifferentiated phenotype. Experiments were grouped by MSCs donor age and we observed after 3 days of culture that stem cells percentage were higher in the fraction $\mathrm{A}(85.04 \pm 13 \%, 66.31 \pm 23 \%)$ and $\mathrm{S}$ $(50.32 \pm 17 \%, 58.74 \pm 16 \%)$ in groups $0-20$ and $21-40$ years comparing the control $\mathrm{C}$ $(31.16+13 \%, 27.42+10 \%)$ respectively. As expected, progenitor cells percentage in these groups were lower, while in the same groups the percentages of progenitors where decreased in the fraction $\mathrm{A}(14.78 \pm 12 \%, 33.64 \pm 22 \%)$ and $\mathrm{S}(49.64 \pm 17 \%, 40.46 \pm 17 \%)$ compared to the control C $(68.8+13 . \%, 72.56 \pm 10 \%)$ respectively. Groups $41-60$ and $>61$ years did not show significative differences, as shown in the Figure 3D. After 7 days of culture stem cells percentage increased only in fraction $A(86.77 \pm 10 \%$, $76.74 \pm 16 \%$ ) of the groups $0-20$ and $21-40$ years comparing to the controls $\mathrm{C}$ 
$(65.17 \pm 9 \%, 56.16 \pm 12 \%)$ respectively. However, progenitors cells where lower in the fraction A $(13.21 \pm 10 \%, 23.26 \pm 16 \%)$ compared to the controls C $(32.52 \pm 9 \%$, $43.81 \pm 12 \%$ ) for the same groups, respectively. The others groups $41-60$ and $>61$ years old did not show significative differences Figure $3 \mathrm{E}$. These results suggest that MSCs aging can decrease their ability of maintain the $\mathrm{HSC}$ s under undifferentiated phenotype.

Cellular aging correlates either with MSCs CXCL12/SDF-1 lower secretion as also to $\mathrm{CXCR} 4$ diminished expression in $\mathrm{HSC}$ s

In general, after 3 and 7 days of culture the amount of CXCL-12 secreted in co-cultures of MSCs and HSCs (day $3-699 \mathrm{pg} / \mathrm{mL} \pm 528 \mathrm{pg} / \mathrm{mL}$; day $7-2527 \mathrm{pg} / \mathrm{mL} \pm$ $1328 \mathrm{pg} / \mathrm{mL}$ ) are significantly higher than in cultures with only HSCs (control) (day3 $72 \mathrm{pg} / \mathrm{mL} \pm 1.75 \mathrm{pg} / \mathrm{mL}$; day $7-7.8 \mathrm{pg} / \mathrm{mL} \pm 4.35 \mathrm{pg} / \mathrm{mL}$ ) as showed in Figure $4 \mathrm{~A}$. These results suggest an import role of MSCs in CXCL12 secretion.

These experiments were grouped by MSCs donor age and we observed higher amount of CXCL12 in supernatant of $0-20,21-40$ and $41-60$ years old that were $56.61 \mathrm{pg} / \mathrm{mL} \pm$ $491.12 \mathrm{pg} / \mathrm{mL}, 820.24 \mathrm{pg} / \mathrm{mL} \pm 343.39 \mathrm{pg} / \mathrm{mL}$ and $1475.17 \mathrm{pg} / \mathrm{mL} \pm 342.33 \mathrm{pg} / \mathrm{mL}$ respectively when compared to the controls $\mathrm{HSC}-71,78 \mathrm{pg} / \mathrm{mL} \pm 1,75 \mathrm{pg} / \mathrm{mL}$ or MSC $321,55 \mathrm{pg} / \mathrm{mL} \pm 283,40 \mathrm{pg} / \mathrm{mL}$. This difference was not observed in e $>61$ years old group - $202,50 \mathrm{pg} / \mathrm{mL} \pm 244,65 \mathrm{pg} / \mathrm{mL}$ as shown in Figure 4B, suggesting that aging may lead to an impairment of CXCL12 secretion by MSCs. In addition, we have used the bone marrow $\mathrm{HSC}$ s paired with MSCs to evaluate their CXCR4 expression as shown in Figure $4 \mathrm{C}-\mathrm{D}$, and we observed a significative decrease, on CXCR4 expression on $\mathrm{HSC}$ s from the $>61$ years.

HSCs cultured with MSCs, mainly the younger ones, are functional and able to generate more colonies forming cells

Clonogenic assays were performed in order to measure colonies forming units such as BFU-E, CFU-GM and CFU-GEMM, as shown in Figure 5A. HSC's co-cultivated with MSCs formed more colonies $206 \pm 59$ compared to the control $154 \pm 24$ as seen in Figure $5 \mathrm{~B}$. These results suggest that $\mathrm{MSC}$ s are able to favor the ability of $\mathrm{HSCs}$ forming colonies. These experiments were grouped by MSCs donor age and we observed that the groups formed: $0-20$ years old $262 \pm 41$ colonies, $21-40$ years old $204 \pm 43$ colonies, $41-60$ years old $179 \pm 31$ colonies, $>61$ years $128 \pm 70$ colonies and controls formed 
around $154 \pm 24$ colonies as seen in Figure 5C. The younger MSCs were able to induce more colonies formation by $\mathrm{HSCs}$, but the same effect was not observed on aged MSCs.

HSCs viability in co-culture show no significative differences in the fractions (S) and (A) or by MSCs aging groups

Cell death assay was performed after 7 days of cell culture and we did not observed significative differences in the percentages of annexin- $\mathrm{V}$ and Propidium iodide between fractions: $\mathrm{A}(11.32 \% \pm 5 \%)$ or $\mathrm{S}(11.01 \%+6 \%)$ and the control $(12.13 \% \pm 4 \%)$ as shown in Figure 6 A-C. These experiments were grouped by MSCs donor age and there were no significative differences in cell death between groups (Figure 6D). These results show a low percentage of cells dying in culture.

\section{DISCUSSION}

Adult bone marrow was described as being a specialized microenvironment composed of several cell types that control HSCs quiescence, self-renewal, proliferation and differentiation [6]. Different cellular populations participate in maintenance of medullar niche homeostasis; however some articles describe the important role of mesenchymal stem cells (MSCs) in this environment, either by cell-cell interaction with HSCs or by secretion of soluble factors [34]. Furthermore, in recent years, the use of MSCs as feeder layers to support HSCs expansion increased due to their ability in maintaining these cells undifferentiate phenotype in vivo and in vitro [35]. Nevertheless, there are no reports in literature how MSCs aging can affect HSCs homeostasis.

Herein, we demonstrated that human MSCs of different ages are functional and therefore suitable for use in this study [31]. Additionally, we presented data showing that $\mathrm{HSC}$ s were viable and functional after isolation and cultivation using cell death (apoptosis and necrosis) and clonogenic assays, corroborating the description that cryopreserved HSC remains functional and can be used to hematopoietic reconstitution in bone marrow transplantation setting $[36,37]$.

HSCs co-cultivated with MSCs showed a particular distribuition in culture wells, a part was suspended in supernatant (S) while another part was adhered to MSCs surface (A). Interesting, these cells showed a very immature phenotype, suggesting that the $\mathrm{HSC}$ s maintenance under undifferentiated states could be MSCs contact-dependent. In addition, $\mathrm{HSCs}(\mathrm{A})$ and $(\mathrm{S})$ maintain more undifferentiated profile when compared to 
the control (C). These results are consistent with data reported by Alakel et al, 2008 and Jing et al, 2010, which suggest the influence of soluble factors and cell-cell contact in HSC's immature profile maintenance $[38,39]$.

We were able to observe significant differences in the percentage of $\mathrm{HSCs}(\mathrm{Lin}-\mathrm{CD} 34+)$ population after MSCs co-culture for seven days in all ages groups, except by the >61 years group, compared to the control. This high percentage of Lin-CD34+ cells suggests MSCs ability of preserving HSCs under undifferentiated phenotype and proposes that MSC aging can interfere in the phenotype maintenance. Our findings corroborate Méndez-Ferrer study that establishes a structurally unique niche in the bone marrow made of MSC-HSC combinations [18].

Regarding HSCs subsets, after three days of culture the percentage of stem cells was higher, while percentage of progentors was lower in the fraction (A) compare to control in the group 0-20 years. Similar data was observed for fractions (A) and (S) in group 21-40 years, after seven days of culture. Older groups show no significant difference, suggesting a marked role of MSCs derived from younger donors in $\mathrm{HSCs}$ undifferentiated phenotype mantainance. This result maybe explained by the results from a study which demonstrated that recovery of blood lineages at one year after transplantation was strongly affected by patients advanced age, occurring in only $29 \%$ of the older patients, compared with $56 \%$ of the younger patients suggesting that the niche aging can affect $\mathrm{HSC}$ s population [40].

SDF-1 chemokine, also known as CXCL-12 is present in the niche and is secreted by several bone marrow cells, mainly described in a specific type of MSCs. CXCL12 plays an important role in $\mathrm{HSC}$ s retaining [41, 42], quiescence [43, 44], and repopulating activity [44].

Therefore, taking the importance of CXCL-12, we evaluate their secretion by MSCs and the expression of CXCR-4, receptor of CXCL-12 on paired HSCS. SDF-1 synthesis and secretion increases with age, except for group $>61$ years that showed a sharp decrease in this chemokine secretion. When comparing the production of CXCL-12 among groups, we note that secretion was lower in groups $0-20$ and $>61$ years compared to the group 41-60 years old. These results suggest that MSCs aging can influence the production of CXCL-12 in the niche, and hence lead to changes in the physiological processes in which this chemokine is involved. 
Next, we evalute the CXCR-4 expression in HSCs derived from the same donors that we isolated the MSCs. This data showed increased expression of CXCR4 according to increased age, except for $>61$ years group, which features a sharp desrease in this expression. Therefore, these results suggest that aging influences CXCL-12 secretion by MSCs as well as expression of CXCR4 by HSCs, indicating that homing [45], retaining [41,42], quiescence [43, 44], and repopulating activity [44] in the bone marrow may experience imbalance in older individuals.

Chambers et al. study have shown that aged HSCs have lower engraftment upon bone marrow transplantation and that aged microenvironment influences $\mathrm{HSC}$ engraftment, corroborating our findings that aged MSCs secrete less CXCL12 and older HSC's express less CXCR4 [46].

CXI12/CXCR4 signaling plays a well known role in cellular homing [45]. However, there are authors proposing a cross-signaling between $\mathrm{CXCL} 12 / \mathrm{CXCR}-4$ and WNT (Wnt5a) pathway, suggesting that this crosstalk can stimulates $\beta$-catenin transcriptional activity in neural progenitors leading to cell survival [47] and also play a role in cell directional movement [48, 49]. Consequently, this cross-signaling should be investigated in the context of hematopoietic stem cells self-renewal in the marrow niche $[49,50]$. Our results showed a diminished ability of aged MSCs cells $>61$ years) in maintain $\mathrm{HSC}$ s under undifferentiated state what could be related to these cells decrease in CXCL12 secretion.

HSCs are functional and multipotent after their co-culture with MSCs, they are able to generate myeloid and erithroyd colonies during clonogenic assays. In addition, we observed that HSCs co-cultured with MSCs were able to generate a higher number of colonies than controls corroborating previous published paper [51]. Regarding aging, our data were only significant when comparing 0-20 years old group to control. This data suggest that $\mathrm{MSC}$ s derived from younger donors are able to enhance $\mathrm{HSCs}$ functional and multipotence abilities in vitro. We also verified the viability of these cells in co-culture and we have found no significative differences in the fractions (S) and (A) or by MSCs aging groups comparing them to controls.

Thus, in this study, we were able to conclude that MSCs derived from younger donors are capable to maintain $\mathrm{HSC}$ s functional and under undifferentiated state, this feature were evident in the experiments using MSCs from young donors ( $0-20$ years group), 
while the same was not seem in experiments using MSCs from older donors $>61$ years). MSCs from elderly secrete less CXCL12 at the same time their $\mathrm{HSC}$ s express less CXCR4. Differences observed in these cells suggest one of the alterations whereby the aging of stromal cells may affect homeostasis of bone marrow microenvironment.

\section{ACKNOWLEDGMENT}

We are grateful to Sociedade Benficente Israelita Brasileira Hospital Albert Einstein for all the support received.

\section{REFERENCES}

1- Linton PJ, Dorsllikind K. Age-related changes in lymphocyte derelopment and function. Nat Immunol.2004 Feb; 5(2):133-9. Review.

2. Lichtman MA, Rowre IM. The relationship of patient age to the pathobiology of the clonal myeloid diseases. Semin Oncol. 2004 Apr; 31(2):185-97. Reriew.

3. Beghe C. Review: interventions targeting intinsic and envirommental risk factors reduce falls in older persons. ACP J Club. 2004 Jul-Aug; 141(1):17.

4. Geiger $\mathrm{H}$, de Haan G, Flonian MC. The ageing haematopoietic stem cell compatment. Nat Rev Immunol. $2013 \mathrm{May} ; 13$ (5):376-89.

5. Lansdorp PM, Dragowska W, Mayani H. Ontogeny-related changes in proliferative potential of human hematopoietic cells. J Exp Med. 1993 Sep 1; 178(3):787-91.

6. Schofield R. The relationship between the spleen colony-forming cell and haemopoietic stem cell. Blood Cells. $1978 ; 4(1-2): 7-25$.

7. Oh IH, Kwon KR Concise review: multiple niches for hematopoietic stem cell regulations. Stem Cells. 2010 Jul; $28(7): 1243-9$.

8. Anthony BA, Link DC. Regulation of hematopoietic stem cells by bone manrow stromal cells. Trends Immunol. $2014 \mathrm{Jan} ; 35(1): 32-7$.

9. Nwajei F, Konopleva M. The bone manrow microentironment as niche reteats for hematopoietic and leukemic stem cells. Adv Hematol. 2013.

10- Kiel MJ, Yllmaz OH, Iwashita T, Yilmaz OH, Terhorst C, Monison SJ. SL.AM family receptors distinguish hematopoietic stem and progenitor cells and reveal endothelial niches for stem cells. Cell. 2005 Jul 1; 121(7):1109-21.

11- Kiel MJ, Radice GL, Monison SJ. Lack of eridence that hematopoietic stem cells depend on Ncadherin-mediated achesion to osteoblasts for their maintenance. Cell Stem Cell. 2007 Aug 16;1 (2):204-17.

12- Nombela-Anieta C, Pirarnik G, Winkel B, Canty KJ, Harley B, Mahoney JE, Park SY, Lu J, Protopopor A, Silberstein LE. Quantitative imaging of haematopoietic stem and progenitor cell localization and hypoxic status in the bone manrow microenvironment. Nat Cell Biol. 2013 May, 15(5): $533-43$,

13- Sugiyama T, Kohara H, Noda M, Nagasarva T. Maintenance of the hematopoietic stem cell pool by CXCL12-CXCR4 chemokine signaling in bone manrow stromal cell niches. Immunity. 2006 Dec; $25(6): 977-88$

14. Ding L, Saunders IL, Enikolopor G, Morrison SJ. Endothelial and perivascular cells maintain haematopoietic stem cells. Nature. $2012 \operatorname{Jan} 25 ; 481(7382): 457-62$. 
15- Greenbaum A, Hsu MM, Day RB, Schuettpelz LG, Chistopher MI, Borgerding IN, Nagasawa T, Link DC. CXCL12 in early mesenchymal progenitors is required for haematopoietic stem-cell maintenance. Nature. $2013 \mathrm{Mar} 14 ; 495(7440): 227-30$.

16- Morikawa S, Mabuchi Y, Kubota Y, Nagai Y, Nibe K, Hiratsu E, Suzuki S,Miyauchi-Hara C, Nagoshi N, Sunabori T, Shimmura S, Miyawaki A, Nakagawa T, Suda T, Okano H, Matsuzaki Y. Prospective identification, isolation, and systemic transplantation of multipotent mesenchymal stem cells in muine bone marrow. JExp Med. 2009 Oct 26; 206(11):2483-96.

17. Katayama Y, Battista M, Kao WM, Hiclalgo A, Peired AJ, Thomas SA, Frenette PS. Signals from the sympathetic nerrous system regulate hematopoietic stem cell egress from bone manow. Cell. $2006 \operatorname{Jan} 27 ; 124(2): 407-21$.

18- Méndez-Fenrer S, Lucas D, Battista M, Frenette PS. Haematopoietic stem cell release is regulated by circadian oscillations. Nature. $2008 \mathrm{Mar} 27 ; 452(7186): 442-7$.

19- Yamazaki S, Ema H, Karlsson G, Yamaguchi T, Miyoshi H, Shioda S, Taketo MM, Karlsson S. Iwama A, Nakauchi H. Nonmyelinating Schwann cells maintain hematopoietic stem cell hibernation in the bone manrow niche. Cell. 2011 Nov $23 ; 147(5): 1146-58$.

20- Willler IG, Sims NA, Pettit AR, Barbier V, Nowlan B, Helwani F, Poulton IJ, van Rooijen N. Alexander KA, Raggatt LJ, Lévesque $\mathrm{P}$. Bone manrow macrophages maintain hematopoietic stem cell (HSC) niches and their depletion mobilizes HSCs. Blood 2010 Dec 2; 116(23):4815. 28.

21- Kollet O, Dar A, Shivtiel S, Kalinkorich A, Lapid K, Sztainberg Y, Tesio M, Samstein RM Goichberg P, Spiegel A, Elson A, Lapidot T. Osteoclasts degrade endosteal components and promote mobilization of hematopoietic progenitor cells.Nat Med. $2006 \mathrm{Jun} ; 12(6): 657-64$.

22- Ding L, Monison SJ. Haematopoietic stem cells and early lymphoid progenitors $\propto c c u p y$ distinct bone marrow niches. Nature. $2013 \mathrm{Mar} 14 ; 495$ (7440):231-5.

23- Taichman RS, Emerson SG. Human osteoblasts suppont hematopoiesis through the production of granulocyte colony-stimulating factor. J Exp Med. 1994 May 1; 179(5):1677-\$2.

24- Visnjic D, Kalajzic Z, Rowe DW, Kataric V, Lorenzo J, Aguila HL. Hematopoiesis is severely altered in mice with an induced osteoblast deficiency. Blood. 2004 May 1; 103(9):3258-64.

25- Zhu J, Ganett R, Jung Y, Zhang Y, Kim N, Wang J, Joe GJ, Hexner E, Choi Y, Taichman RS, Emerson SG. Osteoblasts support B-lymphocyte commitment and differentiation from hematopoietic stem cells. Blood. 2007 May 1;109(9):3706-12.

26- Wagner W, Hom P, Bork S, Ho AD. Aging of hematopoietic stem cells is regulated by the stem cell niche. Exp Gerontol. 2008 Nov;43(11)-974-80.

27. Tokalor SV, Grüner S, Schincler S, Wolf G, Baumann M, Abolmaali N. Age-related changes in the frequency of mesenchymal stem cells in the bone manrow of rats. Stem Cells Dev. 2007 Jun; $16(3): 439-46$

28- Stolzing A, Jones E, McGonagle D, Scutt A, Age-related changes in human bone manowdenived mesenchymal stem cells: consequences for cell therapies, Mech. Ageing Dev: 129 (2008) 163-173.

29- Bellantuono I, Aldahmash A, Kassem M. Aging of manow stromal (skeletal) stem cells and their contribution to age-related bone loss. Biochim Biophys Acta. 2009 Apr,1792(4):364-70.

30- Nakamura-Ishizu A, Suda T. Aging of the hematopoietic stem cells niche. Int J Hematol 2014 Oct:100(4):317-25. doi: 10.1007/s12185-014-1641-8. Epub 2014 Aug 6. Review.

31- Deus GC, Normanton M, Hamerschlak N, Kondo AT, Ribeiro AA, Goldberg AC, Marti LC. Isolation and characterization of mesenchymal stem cells obtained from reusable and disposable bone manrow collection filters. Einstein (Sao Paulo). 2012 Jul-Sep;10 (3):296-301.

32- Normanton M, Alvarenga H, Hamerschlak N, Ribeiro A, Kondo A, Rizzo LV, Marti LC. Interleukin 7 plays a role in $T$ lymphocyte apoptosis inlubition driven by mesenchymal stem cell without faroing proliferation and cytokines secretion. PLoS One. 2014 Sep 3;9(9):e106673.

33- Brocklebank AM, Sparow RL. Enumeration of CD34+ cells in cord blood: a variation on a single-platform flow cytometric method based on the ISHAGE gating strategy. Cytomety. 2001 Aug 15;46(4):254-61. 
34- Omatsu Y, Sugiyama T, Kohara H, Kondoh G, Fujii N, Kolno K, Nagasawa T. The essential functions of adipo-osteogenic progenitors as the hematopoietic stem and progenitor cell niche. Immunity. $2010 \mathrm{Sep} 24 ; 33(3): 387-99$.

35- Wilson A. Trumpp A. Bone-manrow haematopoietic-stem-cell niches. Nat Rev Immunol. 2006 Feb:6(2):93-106

36- Brommeyer HE, Douglas GW, Hangoc G, Cooper S, Bard J, English D, Any M, Thomas I Boyse E.A. Human umbilical cord blood as a potential source of transplantable hematopoietic stem progenitor cells. Proc Natl Acad Sci USA. 1989 May, 86(10):3828-32.

37. Gluckman E, Broxmeyer HA, Auerbach AD, Friedman HS, Douglas GW, Devergie A.Esperou H. Thieny D, Socie G, Lehn P, et al. Hematopoietic reconstitution in apatient with Fancori's anemia by means of umbilical-cord blood from an HLA-identical sibling. N Engl J Mecl. 1989 Oct 26:321(17):1174-8.

38- Alakel N, Jing D, Muller K, Bornhauser M Ehninger G, Ordemann R. Direct contact with mesenchymal stromal cells affects mignatory beharior and gene expression profile of CD133+ hematopoietic stem cells duing ex vivo expansion. Exp Hematol. 2009 Apr,37(4):504-13.

39- Jing D, Fonseca AV, Alakel N, Fieno FA, Muller K, Bornhauser M, Elninger G, Corbeil D, Ordemann $R$. Hematopoietic stem cells in co-culture with mesenchymal stromal cells--modeling the niche compartments in vitro. Haematologica. $2010 \mathrm{Apr} ; 95(4): 542-50$.

40- Woolthuis CM, Mariani N, Verkaik-Schakel RN, Brouwers-Vos A., Schuringa JJ, Vellenga E, de Wolf JT, Huls G. Aging impairs long-term hematopoietic regeneration after autologous stem cell transplantation. Biol Blood Manrow Transplant. $2014 \mathrm{Jun} ; 20(6): 865-71$.

41. Ara T, Itoi M, Kawabata K, Egawa T, Tokoyoda K, Sugiyama T, Fuji N, Amagai T,Nagasawa T. A role of CXC chemokine ligand 12 stromal cell-derived factor-1/pre-B cell growth stimulating factor and its receptor CXCR4 in fetal and actult T cell development in vivo. J Immunol. 2003 May 1;170(9):4649-55

42- Tzeng YS, Li H, Kang YL, Chen WC, Cheng WC, Lai DM. Loss of Cxcl12/Sdf-1 in adult mice decreases the cuiescent state of hematopoietic stem/progenitor cells and alters the pattem of hematopoietic regeneration after myelosuppression. Blood. 2011 Jan 13;117(2):429-39.

43- Nie Y, Han YC, Zou YR CXCR4 is required for the quiescence of primitive hematopoietic cells. J Exp Med. 2008 Apr 14; 205(4):777-83.

44- Renström J., Kröger M., Peschel C., Oostendorp RAJ. How the niche regulates hematopoietic stem cells. Chemico-Biological Interactions. 2010; 184 (1-2): 7-15.

45- Lapidot T, Dar A, Kollet O. How do stem cells find their way home? Blood. 2005 Sep 15;106(6):1901-10. Epub 2005 May 12. Review.

40- Chambers bers SM Shaw CA, Gatza C, Fisk CJ, Donehower LA, Goodell MA. Aging hematopoietic stem cells decline in function and exhibit epigenetic dysregulation. PLoS Biol. 2007;5:e201.

47- Luo Y, Cai J, Xue H, Mattson MP, Rao MS. SDFl $\alpha$ CXCR4 signaling stimulates $\beta$-catenin transcriptional activity in rat newral progenitors. Neurosci Lett. 2006:398:291-29

48- Witze ES, Litman ES, Argast GM, Moon RT, Ahn NG. Wnt5a control of cell polarity and directional movement by polarized redistribution of adhesion receptors. Science. 2008;320:365369

49. Ghosh MC, Collins GD, Vandanmagsar B, Patel K, Brill M, Carter A, Lustig A Becker KG, Wood WW 3rd, Emeche CD, French AD, O'Connell MP, Xu M, Weeraratna AT, Taub DD. Activation of Wnt5A signaling is required for CXC chemokine ligand 12-mediated T-cell migration. Blood 2009 Aug 13;114(7):1366-73.

50- Baron R. Kneissel M. WNT signaling in bone homeostasis and disease: from human mutations to treatments. Nat Med. 2013 Feb;19(2):179-92.

51- Zhang Y, Chai C, Jiang XS, Teoh SH, Leong KW. Co-culture of umbilical cord blood CD34+ cells with human mesenchymal stem cells. Tissue Eng. 2006 Aug; 12(8):2161-70. 


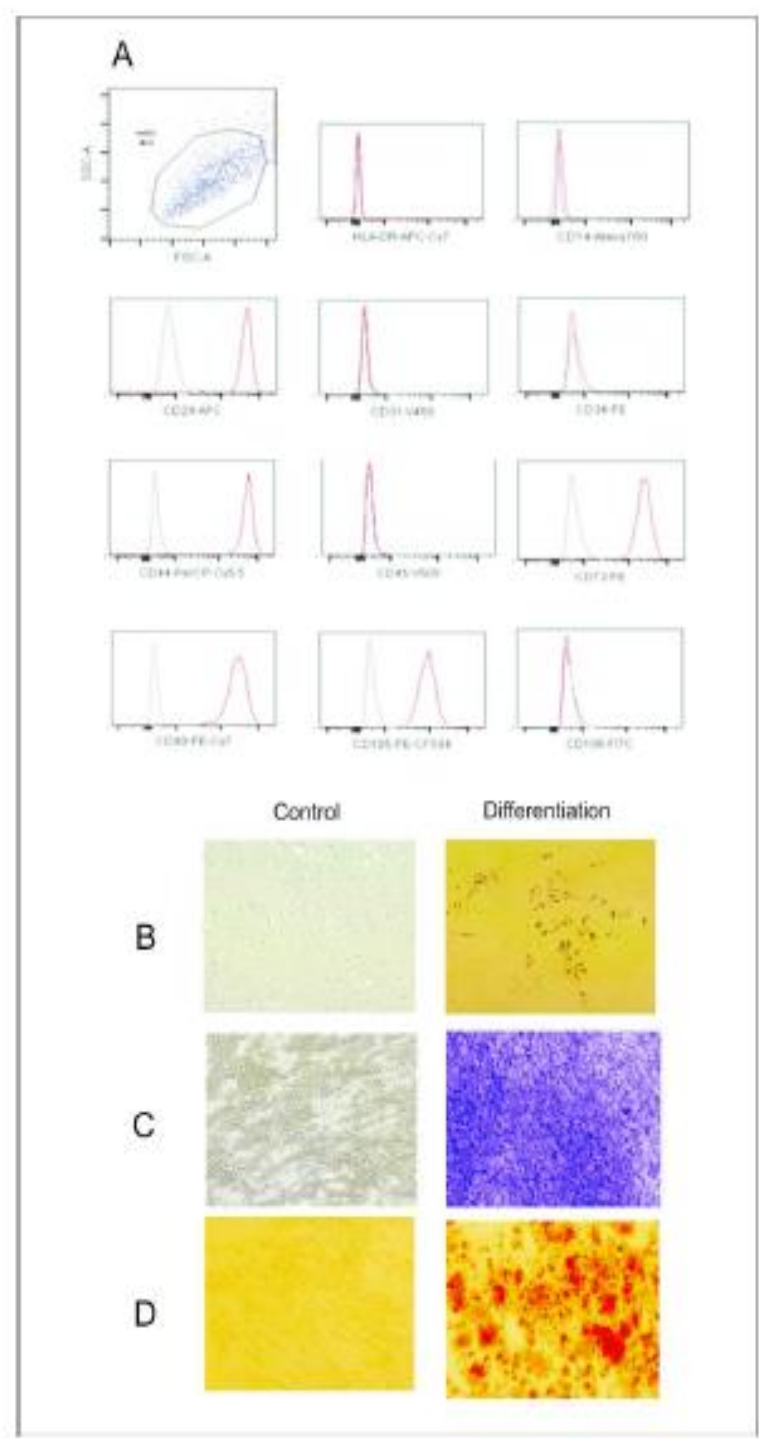

Fiqura 1 -Human mesenchymal stem cell phenotyping and differentiation in 3 mesodermal lineages ( $A$ ) Fluorescence minus one showed in qrey, markers staining showed in red. Cells were first qated on SSC vs FSC, than analysed for each marker, Less than $1 \%$ of MSCs expressed CD106, CD 34, CD 45, CD 31, CD14 and HLA-DR. At lest $99 \%$ of the analysed MSCs expressed CD29, CD44, CD73, CD90 and CD105 (B) Oil red staining adipocytes, showing lipid drops (C) Toluidine blue stain condroblast and evidence the presence of proteoblicans (D) Alizarin red stain osteoblast and show presence of calcium deposits. (20x)

$151 \times 265 \mathrm{~mm}(300 \times 300 \mathrm{DPI})$ 

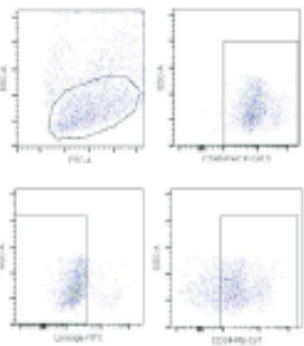

D

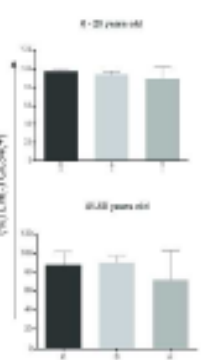

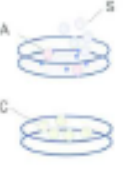

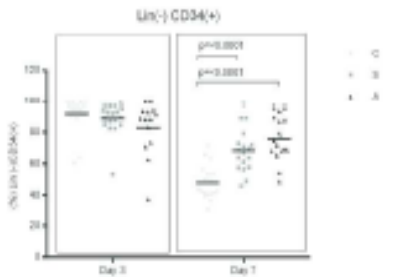

E

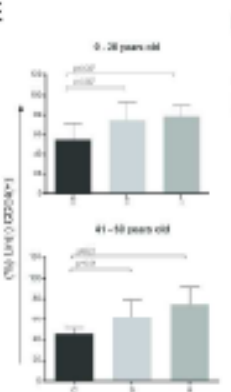

Day ?

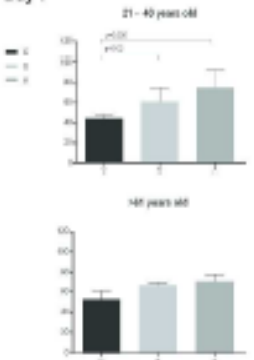

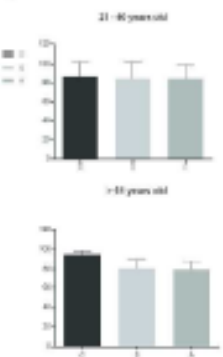

Figure 2 - HSC co-culture with MSCs favors Lin-CD34+ stem cells maintenance. (A) Hematopoietic stem cells (HSCs) derived from umbilical cord blood samples $(n=20)$ were characterized (CD45+ Lineage- CD34+) by flow cytometry according the gate strategy using the ISHAGE protocol. (B) MSCs from healthy bone marrow donors $(n=19)$ were plated and after co-cultured with HSCs at ratio 2:1 during 3 or 7 days HSCs were identified according distribution on culture well: control "C" were HSCs cultured alone, while HSCs cocultured with MSCs were divided in two fractions, those in supernantant called " $\mathrm{S}$ " and other adhered fraction named "A" (C) Percentage of C, A and S HSCs (D) groups divided by age: $0-20$ years old $(n=-6)$; 21-40 years old $(n=5) ; 41-60$ years old $(n=5)$ and $>61$ years old $(n=3)$ after 3 and $(E) 7$ days of co-culture.

$395 \times 319 \mathrm{~mm}(300 \times 300 \mathrm{DPI})$ 


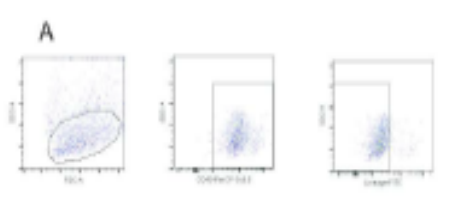

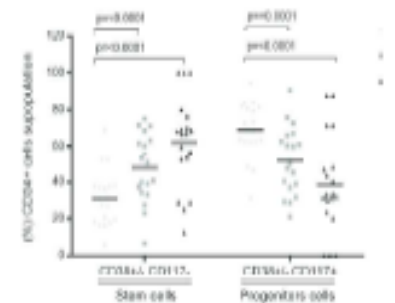

D

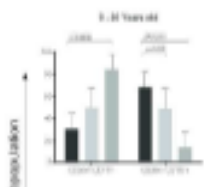

4.

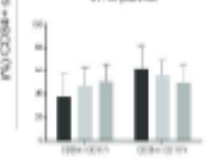

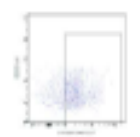

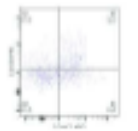

Day 3

romatis nots
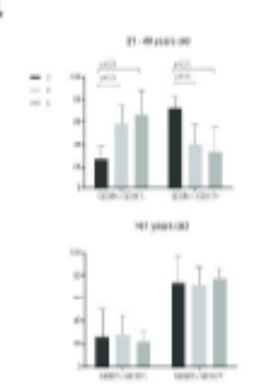

Dey 7
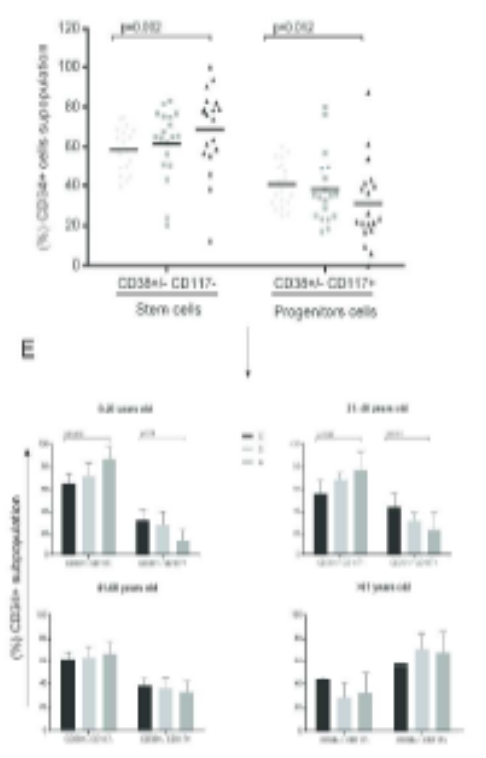

Fiqure 3 - MSCs are able to maintain undifferentiated phenotype on hematopoietic cells. (A) HSCs (CD45+ Lineage- $\mathrm{CD} 34+$ ) subpopulations were identified as stem cells (CD38+/-CD117-) or proqenitors cells (CD38+/-CD117-) by flow cytometry according gate strategy using ISHAGE protocol. (B) Percentage of stem cells and progenitors cells from $\mathrm{C}, \mathrm{A}$ and $\mathrm{S}$ groups after 3 and (C) 7 days. (D) Percentages of $\mathrm{C}, \mathrm{A}$ and $S$ qrouped by aqe: $0-20$ years $(n=6) ; 21-40$ years $(n=5) ; 41-60$ years $(n=5)$ and $>61$ years $(n=3)$ after 3 and $(E) 7$ days of co-culture.

$406 \times 431 \mathrm{~mm}(300 \times 300 \mathrm{DPI})$ 
A

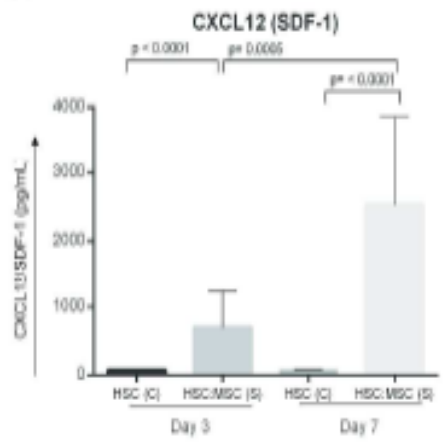

$\mathrm{C}$
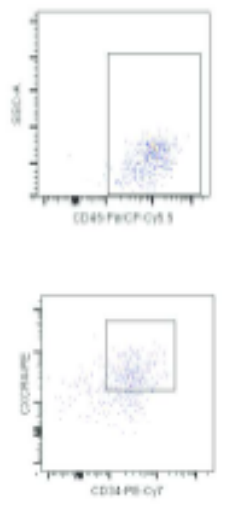

B

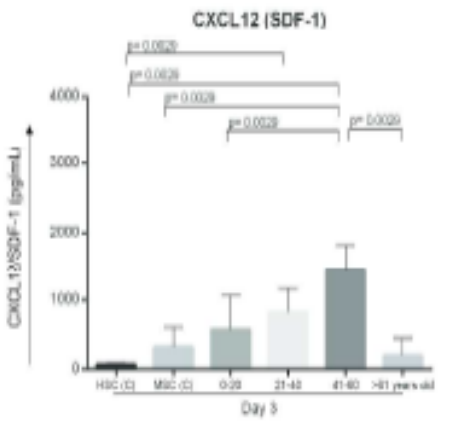

D

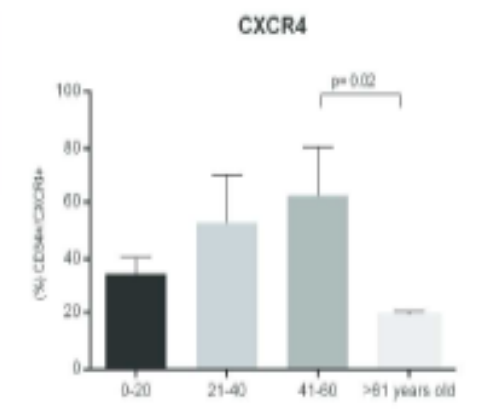

Figure 4 - Impaired CXCR4 expression and production of its ligand CXCL12 are associated with MSC and HSCs aqing. MSCs from healthy bone marrow donors $(n=13)$ were plated and after co-cultured with HSCs derived from umbilical cord blood samples at ratio 2:1 during 3 or 7 days. The control " $\mathrm{C}^{\prime \prime}$ aroup correspond HSCs cultured alone. (A) After the cultivation time the CXCL12 production was measured by ELISA from supernatants of all samples in (B) controls, MSCs alone (04), HSCs alone (04) and qrouped by aqe: $0-20$ years old $(n=4) ; 21-40$ years old $(n=4) ; 41-60$ years old $(n=3)$ and $>61$ years old $(n=2)$. (C) HSCs were

characterized (CD45+ Lineage- CD34+) and CXCR4 by flow cytometry according the gate strategy recommended in the ISHAGE protocol. (D) After, the frequency of HSCs expressing CXCR4 and grouped by aqe was evaluated by flow cytometry.

$291 \times 298 \mathrm{~mm}(300 \times 300 \mathrm{DPI})$ 
A
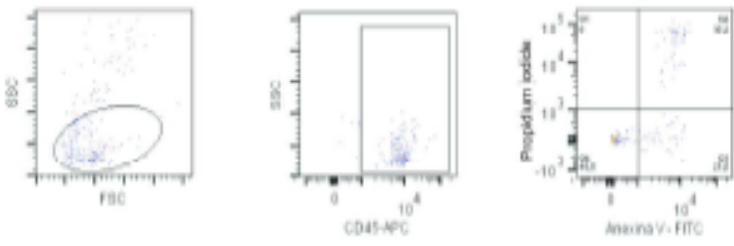

B

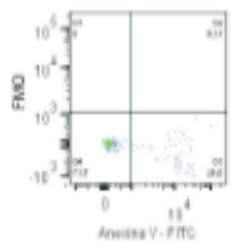

$C$

(S) Cell death

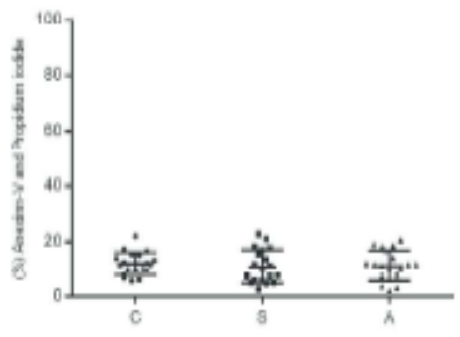

(W) Cell death

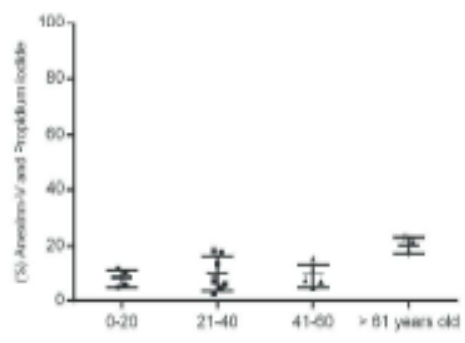

Figure 6 - MSCs age did not affect HSCs survival during co-culture. HSCs were cultured alone or with MSCs ( $n=16$ ) previously plated at ratio 1:2 during 7 days. (A) HSCs viability (CD45+) subpopulations was evaluated by flow cytometry analysis of annexin- $V$ and propidium iodide staining. (B) Fluorescence minus one (FMO) for both staining protocol was determined by absence of one staning marker in each channel (C) Viability of different HSCs qroups cultured alone, adhered to MSCs, and HSCs in the supernatant, C, A and S respectivelyor $(D)$ arouped by different aqes

$259 \times 275 \mathrm{~mm}(300 \times 300 \mathrm{DPI})$ 


\section{0- Referências bibliográficas}

1. Linton PJ, Dorshkind K. Age-related changes in lymphocyte development and function. Nat Immunol.2004 Feb; 5(2):133-9. Review.

2. Metze IL Síndrome miélodisplásica. Conceito e classificação. Diagnóstico. Evolução e complicações. Tratamento. In: ZAGO, M. A.; FALCÃO, R. P.; PASQUINI, R. Hematologia fundamentos e prática. São Paulo: Atheneu, 2004. cap. 3 p. 23-31.

3. Lorenzi TF, et al. Manual de hematologia propedêutica e clínica. 4 ed. Rio de Janeiro: Guanabara koogan, 2006. 710 p.

4. Lichtman MA, Rowe JM. The relationship of patient age to the pathobiology of the clonal myeloid diseases. Semin Oncol. 2004 Apr; 31(2):185-97. Review.

5. Beghe C. Review: interventions targeting intrinsic and environmental risk factors reduce falls in older persons. ACP J Club. 2004 Jul-Aug; 141(1):17.

6. Geiger H, de Haan G, Florian MC. The ageing haematopoietic stem cell compartment. Nat Rev Immunol. 2013 May;13(5):376-89.

7. Lansdorp PM, Dragowska W, Mayani H. Ontogeny-related changes in proliferative potential of human hematopoietic cells. J Exp Med. 1993 Sep 1; 178(3):787-91.

8. Sugiyama T, Nagasawa T. Bone marrow niches for hematopoietic stem cells and immune cells. InflammAllergy Drug Targets. 2012 Jun; 11(3):201-6. Review

9. Nagasawa T. Microenvironmental niches in the bone marrow required for B-cell development.Nat Rev Immunol. 2006 Feb; 6(2):107-16. Review.

10. Mendelson A, Frenette PS. Hematopoietic stem cell niche maintenance during homeostasis and regeneration. Nat Med. 2014 Aug; 20(8):833-46.

11. Mosaad YM. Hematopoietic stem cells: an overview. Transfus Apher Sci. 2014 Dec; 51(3):68-82.

12. Chotinantakul K, Leeanansaksiri W. Hematopoietic stem cell development, niches, and signaling pathways. Bone Marrow Res. 2012; 2012:270425.

13. Lord BI, Testa NG, Hendry JH. The relative spatial distributions of CFUs and CFUc in the normal mouse femur. Blood. $1975 \mathrm{Jul}$; 46(1):65-72.

14. Dexter TM, Allen TD, Lajtha LG. Conditions controlling the proliferation of haemopoietic stem cells in vitro. J Cell Physiol. 1977 Jun; 91(3):335-44. 
15. Zipori D, Duksin D, Tamir M, Argaman A, Toledo J, Malik Z. Cultured mouse marrow stromal cell lines. II. Distinct subtypes differing in morphology, collagen types, myelopoietic factors, and leukemic cell growth modulating activities. J Cell Physiol. 1985 Jan; 122(1):81-90.

16. Schofield R. The relationship between the spleen colony-forming cell and the haemopoietic stem cell. Blood Cells. 1978; 4(1-2):7-25.

17. Xie T, Spradling AC. decapentaplegic is essential for the maintenance and division of germline stem cells in the Drosophila ovary. Cell. 1998 Jul 24; 94(2):251-60.

18. Oh IH, Kwon KR. Concise review: multiple niches for hematopoietic stem cell regulations. Stem Cells. 2010 Jul; 28(7):1243-9.

19. Anthony BA, Link DC. Regulation of hematopoietic stem cells by bone marrow stromal cells. Trends Immunol. 2014 Jan; 35(1):32-7.

20. Nwajei F, Konopleva M. The bone marrow microenvironment as niche retreats for hematopoietic and leukemic stem cells. Adv Hematol. 2013.

21. Morrison SJ, Scadden DT. The bone marrow niche for haematopoietic stem cells. Nature. 2014 Jan 16; 505(7483):327-34.

22. Kiel MJ, Yilmaz OH, Iwashita T, Yilmaz OH, Terhorst C, Morrison SJ. SLAM family receptors distinguish hematopoietic stem and progenitor cells and reveal endothelial niches for stem cells. Cell. 2005 Jul 1; 121(7):1109-21.

23. Kiel MJ, Radice GL, Morrison SJ. Lack of evidence that hematopoietic stem cells depend on $\mathrm{N}$-cadherin-mediated adhesion to osteoblasts for their maintenance. Cell Stem Cell. 2007 Aug 16;1(2):204-17

24. Nombela-Arrieta C, Pivarnik G, Winkel B, Canty KJ, Harley B, Mahoney JE, Park SY, Lu J, Protopopov A, Silberstein LE. Quantitative imaging of haematopoietic stem and progenitor cell localization and hypoxic status in the bone marrow microenvironment. Nat Cell Biol. 2013 May; 15(5):533-43

25. Sugiyama T, Kohara H, Noda M, Nagasawa T. Maintenance of the hematopoietic stem cell pool by CXCL12-CXCR4 chemokine signaling in bone marrow stromal cell niches. Immunity. 2006 Dec; 25(6):977-88.

26. Ding L, Saunders TL, Enikolopov G, Morrison SJ. Endothelial and perivascular cells maintain haematopoietic stem cells. Nature. 2012 Jan 25; 481(7382):457-62. 
27. Ding L, Morrison SJ. Haematopoietic stem cells and early lymphoid progenitors occupy distinct bone marrow niches. Nature. 2013 Mar 14; 495(7440):231-5.

28. Greenbaum A, Hsu YM, Day RB, Schuettpelz LG, Christopher MJ, Borgerding JN, Nagasawa T, Link DC. CXCL12 in early mesenchymal progenitors is required for haematopoietic stem-cell maintenance. Nature. 2013 Mar 14; 495(7440):22730.

29. Morikawa S, Mabuchi Y, Kubota Y, Nagai Y, Niibe K, Hiratsu E, Suzuki S,Miyauchi-Hara C, Nagoshi N, Sunabori T, Shimmura S, Miyawaki A, Nakagawa T, Suda T, Okano H, Matsuzaki Y. Prospective identification, isolation, and systemic transplantation of multipotent mesenchymal stem cells in murine bone marrow. JExp Med. 2009 Oct 26; 206(11):2483-96.

30. Katayama Y, Battista M, Kao WM, Hidalgo A, Peired AJ, Thomas SA, Frenette PS. Signals from the sympathetic nervous system regulate hematopoietic stem cell egress from bone marrow. Cell. 2006 Jan 27; 124(2):407-21.

31. Méndez-Ferrer S, Lucas D, Battista M, Frenette PS. Haematopoietic stem cell release is regulated by circadian oscillations. Nature. 2008 Mar 27; 452(7186):442-7.

32. Yamazaki S, Ema H, Karlsson G, Yamaguchi T, Miyoshi H, Shioda S, Taketo MM, Karlsson S, Iwama A, Nakauchi H. Nonmyelinating Schwann cells maintain hematopoietic stem cell hibernation in the bone marrow niche. Cell. 2011 Nov 23; 147(5):1146-58.

33. Winkler IG, Sims NA, Pettit AR, Barbier V, Nowlan B, Helwani F, Poulton IJ, van Rooijen N, Alexander KA, Raggatt LJ, Lévesque JP. Bone marrow macrophages maintain hematopoietic stem cell (HSC) niches and their depletion mobilizes HSCs. Blood. 2010 Dec 2; 116(23):4815-28.

34. Kollet O, Dar A, Shivtiel S, Kalinkovich A, Lapid K, Sztainberg Y, Tesio M, Samstein RM, Goichberg P, Spiegel A, Elson A, Lapidot T. Osteoclasts degrade endosteal components and promote mobilization of hematopoietic progenitor cells.Nat Med. 2006 Jun; 12(6):657-64.

35. Taichman RS, Emerson SG. Human osteoblasts support hematopoiesis through the production of granulocyte colony-stimulating factor. J Exp Med. 1994 May 1; 179(5):1677-82. 
36. Visnjic D, Kalajzic Z, Rowe DW, Katavic V, Lorenzo J, Aguila HL. Hematopoiesis is severely altered in mice with an induced osteoblast deficiency. Blood. 2004 May 1; 103(9):3258-64.

37. Zhu J, Garrett R, Jung Y, Zhang Y, Kim N, Wang J, Joe GJ, Hexner E, Choi Y, Taichman RS, Emerson SG. Osteoblasts support B-lymphocyte commitment and differentiation from hematopoietic stem cells. Blood. 2007 May 1;109(9):370612.

38. Calvi LM, Adams GB, Weibrecht KW, Weber JM, Olson DP, Knight MC, Martin RP,Schipani E, Divieti P, Bringhurst FR, Milner LA, Kronenberg HM, Scadden DT.Osteoblastic cells regulate the haematopoietic stem cell niche. Nature. 2003 Oct $23 ; 425(6960): 841-6$.

39. Ehninger A, Trumpp A. The bone marrow stem cell niche grows up: mesenchymal stem cells and macrophages move in. J Exp Med. 2011 Mar 14; 208(3):421-8.

40. Jung Y, Wang J, Schneider A, Sun YX, Koh-Paige AJ, Osman NI, McCauley LK, Taichman RS. Regulation of SDF-1 (CXCL12) production by osteoblasts; a possible mechanism for stem cell homing. Bone. 2006 Apr; 38(4):497-508.

41. Stier S, Ko Y, Forkert R, Lutz C, Neuhaus T, Grünewald E, Cheng T, Dombkowski D, Calvi LM, Rittling SR, Scadden DT. Osteopontin is a hematopoietic stem cell niche component that negatively regulates stem cell pool size. J Exp Med. 2005 Jun 6; 201(11):1781-91.

42. Arai F, Hirao A, Ohmura M, Sato H, Matsuoka S, Takubo K, Ito K, Koh GY, Suda T. Tie2/angiopoietin-1 signaling regulates hematopoietic stem cell quiescence in the bone marrow niche. Cell. 2004 Jul 23;118(2):149-61

43. Qian H, Buza-Vidas N, Hyland CD, Jensen CT, Antonchuk J, Månsson R, Thoren LA, Ekblom M, Alexander WS, Jacobsen SE. Critical role of thrombopoietin in maintaining adult quiescent hematopoietic stem cells. Cell Stem Cell. 2007 Dec $13 ; 1(6): 671-84$.

44. Nakamura Y, Arai F, Iwasaki H, Hosokawa K, Kobayashi I, Gomei Y, Matsumoto Y, Yoshihara H, Suda T. Isolation and characterization of endosteal niche cell populations that regulate hematopoietic stem cells. Blood. 2010 Sep 2; 116(9):1422-32.

45. Zhang J, Niu C, Ye L, Huang H, He X, Tong WG, Ross J, Haug J, Johnson T, Feng JQ, Harris S, Wiedemann LM, Mishina Y, Li L. Identification of the 
haematopoietic stem cell niche and control of the niche size. Nature. 2003 Oct 23; 425(6960):836-41.

46. Hosokawa K, Arai F, Yoshihara H, Iwasaki H, Nakamura Y, Gomei Y, Suda T.Knockdown of $\mathrm{N}$-cadherin suppresses the long-term engraftment of hematopoietic stem cells. Blood. 2010 Jul 29; 116(4):554-63.

47. Hosokawa K, Arai F, Yoshihara H, Iwasaki H, Hembree M, Yin T, Nakamura Y,Gomei Y, Takubo K, Shiama H, Matsuoka S, Li L, Suda T. Cadherin-based adhesion is a potential target for niche manipulation to protect hematopoietic stem cells in adult bone marrow. Cell Stem Cell. 2010 Mar 5; 6(3):194-8.

48. Kiel MJ, Acar M, Radice GL, Morrison SJ. Hematopoietic stem cells do not depend on N-cadherin to regulate their maintenance. Cell Stem Cell. 2009 Feb 6;4(2):170-9

49. Li P, Zon LI. Resolving the controversy about N-cadherin and hematopoietic stem cells. Cell Stem Cell. 2010; 6(3):199-202.

50. Bromberg O, Frisch BJ, Weber JM, Porter RL, Civitelli R, Calvi LM. Osteoblastic $\mathrm{N}$-cadherin is not required for microenvironmental support and regulation of hematopoietic stem and progenitor cells. Blood. 2012 Jul 12;120(2):303-13.

51. Greenbaum AM, Revollo LD, Woloszynek JR, Civitelli R, Link DC. N-cadherin in osteolineage cells is not required for maintenance of hematopoietic stem cells. Blood. 2012 Jul 12; 120(2):295-302.

52. Kollet O, Dar A, Shivtiel S, Kalinkovich A, Lapid K, Sztainberg Y, Tesio M, Samstein RM, Goichberg P, Spiegel A, Elson A, Lapidot T. Osteoclasts degrade endosteal components and promote mobilization of hematopoietic progenitor cells. Nat Med. 2006 Jun; 12(6):657-64.

53. Friedenstein AJ, Latzinik NW, Grosheva AG, Gorskaya UF. Marrow microenvironment transfer by heterotopic transplantation of freshly isolated and cultured cells in porous sponges. Exp Hematol. 1982 Feb; 10(2):217-27.

54. Friedenstein AJ, Petrakova KV, Kurolesova AI, Frolova GP. Heterotopic of bone marrow. Analysis of precursor cells for osteogenic and hematopoietic tissues.Transplantation. 1968 Mar; 6(2):230-47.

55. Caplan AI. Mesenchymal stem cells. J Orthop Res. 1991 Sep; 9(5):641-50.

56. Dominici M, Le Blanc K, Mueller I, Slaper-Cortenbach I, Marini F, Krause DS,Deans R, Keating A, Prockop Dj, Horwitz E. Minimal criteria for defining 
multipotent mesenchymal stromal cells. The International Society for Cellular Therapy position statement. Cytotherapy. 2006;8(4):315-7

57. Tormin A, Li O, Brune JC, Walsh S, Schütz B, Ehinger M, Ditzel N, Kassem M,Scheding S. CD146 expression on primary nonhematopoietic bone marrow stem cells is correlated with in situ localization. Blood. 2011 May 12; 117(19):5067-77.

58. Sacchetti B, Funari A, Michienzi S, Di Cesare S, Piersanti S, Saggio I, Tagliafico E, Ferrari S, Robey PG, Riminucci M, Bianco P. Self-renewing osteoprogenitors in bone marrow sinusoids can organize a hematopoietic microenvironment. Cell. 2007 Oct 19; 131(2):324-36.

59. Chan CK, Chen CC, Luppen CA, Kim JB, DeBoer AT, Wei K, Helms JA, Kuo CJ, Kraft DL, Weissman IL. Endochondral ossification is required for haematopoietic stem-cell niche formation. Nature. 2009 Jan 22; 457(7228):490-4.

60. Guerreiro R. et al, As quimiocinas e os seus receptores, Acta Med Port,2011;24 (S4): 967-976.

61. Nagasawa T, Kikutani H, Kishimoto T. Molecular cloning and structure of a preB-cell growth-stimulating factor. Proc Natl Acad Sci U S A. 1994 Mar 15; 91(6):2305-9.

62. Nagasawa T, Hirota S, Tachibana K, Takakura N, Nishikawa S, Kitamura Y, Yoshida N, Kikutani H, Kishimoto T. Defects of B-cell lymphopoiesis and bone-marrow myelopoiesis in mice lacking the CXC chemokine PBSF/SDF-1. Nature.1996 Aug 15; 382(6592):635-8.

63. Tokoyoda K, Egawa T, Sugiyama T, Choi BI, Nagasawa T. Cellular niches controlling B lymphocyte behavior within bone marrow during development. Immunity. 2004 Jun; 20(6):707-18.

64. Kohara H, Omatsu Y, Sugiyama T, Noda M, Fujii N, Nagasawa T. Development of plasmacytoid dendritic cells in bone marrow stromal cell niches requires CXCL12-CXCR4 chemokine signaling. Blood. 2007 Dec 15; 110(13):4153-60.

65. Noda M, Omatsu Y, Sugiyama T, Oishi S, Fujii N, Nagasawa T. CXCL12-CXCR4 chemokine signaling is essential for NK-cell development in adult mice. Blood.2011 Jan 13; 117(2):451-8. 
66. Omatsu Y, Sugiyama T, Kohara H, Kondoh G, Fujii N, Kohno K, Nagasawa T. The essential functions of adipo-osteogenic progenitors as the hematopoietic stem and progenitor cell niche. Immunity. 2010 Sep 24; 33(3):387-99.

67. Méndez-Ferrer S, Michurina TV, Ferraro F, Mazloom AR, Macarthur BD, Lira SA, Scadden DT, Ma'ayan A, Enikolopov GN, Frenette PS. Mesenchymal and haematopoietic stem cells form a unique bone marrow niche. Nature. 2010 Aug $12 ; 466(7308): 829-34$.

68. Pinho S, Lacombe J, Hanoun M, Mizoguchi T, Bruns I, Kunisaki Y, Frenette PS. PDGFR $\alpha$ and CD51 mark human nestin+ sphere-forming mesenchymal stem cells capable of hematopoietic progenitor cell expansion. J Exp Med. 2013 Jul 1; 210(7):1351-67.

69. Lendahl U, Zimmerman LB, McKay RD. CNS stem cells express a new class of intermediate filament protein. Cell. 1990 Feb 23; 60(4):585-95.

70. Day K, Shefer G, Richardson JB, Enikolopov G, Yablonka-Reuveni Z. NestinGFP reporter expression defines the quiescent state of skeletal muscle satellite cells. Dev Biol. 2007 Apr 1;304(1):246-59

71. Phinney DG, Prockop DJ. Concise review: mesenchymal stem/multipotent stromal cells: the state of transdifferentiation and modes of tissue repair--current views. Stem Cells. 2007;25(11):2896-902.

72. Chen MJ, Yokomizo T, Zeigler BM, Dzierzak E, Speck NA. Runx1 is required for the endothelial to haematopoietic cell transition but not thereafter. Nature.2009 Feb 12;457(7231):887-91.

73. Wright DE, Wagers AJ, Gulati AP, Johnson FL, Weissman IL. Physiological migration of hematopoietic stem and progenitor cells. Science. 2001 Nov 30;294(5548):1933-6.

74. Kiel MJ, Yilmaz OH, Morrison SJ. CD150- cells are transiently reconstituting multipotent progenitors with little or no stem cell activity. Blood. 2008 Apr 15;111(8):4413-4; author reply 4414-5.

75. Storb R, Graham TC, Epstein RB, Sale GE, Thomas ED. Demonstration of hemopoietic stem cells in the peripheral blood of baboons by cross circulation.Blood. 1977 Sep;50(3):537-42. 
76. Chute JP, Muramoto GG, Dressman HK, Wolfe G, Chao NJ, Lin S. Molecular profile and partial functional analysis of novel endothelial cell-derived growth factors that regulate hematopoiesis. Stem Cells. 2006 May; 24(5):1315-27.

77. Butler JM, Nolan DJ, Vertes EL, Varnum-Finney B, Kobayashi H, Hooper AT,Seandel M, Shido K, White IA, Kobayashi M, Witte L, May C, Shawber C, Kimura Y,Kitajewski J, Rosenwaks Z, Bernstein ID, Rafii S. Endothelial cells are essential for the self-renewal and repopulation of Notch-dependent hematopoietic stem cells. Cell Stem Cell. 2010 Mar 5;6(3):251-64.

78. Kobayashi H, Butler JM, O'Donnell R, Kobayashi M, Ding BS, Bonner B, Chiu VK, Nolan DJ, Shido K, Benjamin L, Rafii S. Angiocrine factors from Aktactivated endothelial cells balance self-renewal and differentiation of haematopoietic stem cells. Nat Cell Biol. 2010 Nov; 12(11):1046-

79. Hooper AT, Butler JM, Nolan DJ, Kranz A, Iida K, Kobayashi M, Kopp HG, ShidoK, Petit I, Yanger K, James D, Witte L, Zhu Z, Wu Y, Pytowski B, Rosenwaks Z,Mittal V, Sato TN, Rafii S. Engraftment and reconstitution of hematopoiesis isdependent on VEGFR2-mediated regeneration of sinusoidal endothelial cells. CellStem Cell. 2009 Mar 6; 4(3):263-74.

80. Winkler IG, Barbier V, Nowlan B, Jacobsen RN, Forristal CE, Patton JT, Magnani JL, Lévesque JP. Vascular niche E-selectin regulates hematopoietic stem cell dormancy, self renewal and chemoresistance. Nat Med. 2012 Nov; 18(11):1651-7.

81. Naveiras O, Nardi V, Wenzel PL, Hauschka PV, Fahey F, Daley GQ. Bonemarrowadipocytes as negative regulators of the haematopoietic microenvironment. Nature.2009 Jul 9; 460(7252):259-63.

82. Yamazaki S, Iwama A, Takayanagi S, Eto K, Ema H, Nakauchi H. TGF-beta as a candidate bone marrow niche signal to induce hematopoietic stem cell hibernation. Blood. 2009 Feb 5; 113(6):1250-6.

83. Chow A, Lucas D, Hidalgo A, Méndez-Ferrer S, Hashimoto D, Scheiermann C,Battista M, Leboeuf M, Prophete C, van Rooijen N, Tanaka M, Merad M, Frenette PS.Bone marrow CD169+ macrophages promote the retention of hematopoietic stem and progenitor cells in the mesenchymal stem cell niche. J Exp Med. 2011 Feb 14;208(2):261-71 
84. Christopher MJ, Rao M, Liu F, Woloszynek JR, Link DC. Expression of the GCSF receptor in monocytic cells is sufficient to mediate hematopoietic progenitor mobilization by G-CSF in mice. J Exp Med. 2011 Feb 14; 208(2):251-60.

85. Fleming WH, Alpern EJ, Uchida N, Ikuta K, Spangrude GJ, Weissman IL. Functional heterogeneity is associated with the cell cycle status of murine hematopoietic stem cells. J Cell Biol. 1993 Aug; 122(4):897-902.

86. Ratajczak MZ, Zuba-Surma E, Kucia M, Reca R, Wojakowski W, Ratajczak J. The pleiotropic effects of the SDF-1-CXCR4 axis in organogenesis, regeneration and tumorigenesis. Leukemia. 2006 Nov; 20(11):1915-24.

87. Peled A, Petit I, Kollet O, Magid M, Ponomaryov T, Byk T, Nagler A, Ben-Hur H,Many A, Shultz L, Lider O, Alon R, Zipori D, Lapidot T. Dependence of human stem cell engraftment and repopulation of NOD/SCID mice on CXCR4. Science. 1999 Feb 5;283(5403):845-8.

88. Kollet O, Shivtiel S, Chen YQ, Suriawinata J, Thung SN, Dabeva MD, Kahn J,Spiegel A, Dar A, Samira S, Goichberg P, Kalinkovich A, Arenzana-Seisdedos F,Nagler A, Hardan I, Revel M, Shafritz DA, Lapidot T. HGF, SDF-1, and MMP9 are involved in stress-induced human CD34+ stem cell recruitment to the liver. J Clin Invest. 2003 Jul;112(2):160-9.

89. Frassoni F, Podesta M, Maccario R, Giorgiani G, Rossi G, Zecca M, Bacigalupo A, Piaggio G, Locatelli F. Cord blood transplantation provides better reconstitution of hematopoietic reservoir compared with bone marrow transplantation. Blood. 2003 Aug 1;102(3):1138-41.

90. Balabanian K, Lagane B, Infantino S, Chow KY, Harriague J, Moepps B Arenzana-Seisdedos F, Thelen M, Bachelerie F. The chemokine SDF1/CXCL12 binds to and signals through the orphan receptor RDC1 in T lymphocytes. J Biol Chem. 2005 Oct 21; 280(42):35760-6.

91. Braun M, Wunderlin M, Spieth K, Knöchel W, Gierschik P, Moepps B. Xenopus laevis Stromal cell-derived factor 1: conservation of structure and function during vertebrate development. J Immunol. 2002 Mar 1; 168(5):2340-7.

92. Renström J., Kröger M., Peschel C., Oostendorp RAJ. How the niche regulates hematopoietic stem cells. Chemico-Biological Interactions [Internet]. 2010 [citado 2014 Set. 16]; 184 (1-2): 7-15. 
93. Lam BS, Adams GB. Hematopoietic stem cell lodgment in the adult bone marrow stem cell niche. Int J Lab Hematol [Internet]. 2010 [citado 2014 Set. 6]; 32(6): 5518.

94. Lapidot T, Dar A, Kollet O. How do stem cells find their way home? Blood. 2005 Sep 15;106(6):1901-10. Epub 2005 May 12. Review.

95. Askenasy N, Farkas DL. Optical imaging of PKH-labeled hematopoietic cells in recipient bone marrow in vivo. Stem Cells. 2002;20(6):501-13.

96. Ponomaryov T, Peled A, Petit I, Taichman RS, Habler L, Sandbank J,ArenzanaSeisdedos F, Magerus A, Caruz A, Fujii N, Nagler A, Lahav M, Szyper-Kravitz M, Zipori D, Lapidot T. Induction of the chemokine stromal-derived factor-1 following DNA damage improves human stem cell function. J Clin Invest.2000 Dec;106(11):1331-9.

97. McCulloch EA. Stem cells in normal and leukemic hemopoiesis (Henry Stratton Lecture, 1982). Blood. 1983 Jul;62(1):1-13.

98. Cozzio A, Passegué E, Ayton PM, Karsunky H, Cleary ML, Weissman IL. Similar MLL-associated leukemias arising from self-renewing stem cells and short-lived myeloid progenitors. Genes Dev. 2003 Dec 15;17(24):3029-35.

99. Liles WC, Broxmeyer HE, Rodger E, Wood B, Hübel K, Cooper S, Hangoc G, Bridger GJ, Henson GW, Calandra G, Dale DC. Mobilization of hematopoietic progenitor cells in healthy volunteers by AMD3100, a CXCR4 antagonist. Blood. 2003 Oct 15;102(8):2728-30.

100. Ceradini DJ, Kulkarni AR, Callaghan MJ, Tepper OM, Bastidas N, Kleinman ME,Capla JM, Galiano RD, Levine JP, Gurtner GC. Progenitor cell trafficking is regulated by hypoxic gradients through HIF-1 induction of SDF-1. Nat Med. 2004 Aug;10(8):858-64.

101. Kortesidis A, Zannettino A, Isenmann S, Shi S, Lapidot T, Gronthos S.Stromalderived factor-1 promotes the growth, survival, and development of human bone marrow stromal stem cells. Blood. 2005 May 15;105(10):3793-801.

102. Tzheng YS, Li H, Kang YL, Chen WC, Cheng WC, Lai DM. Loss of Cxc112/Sdf-1 in adult mice decreases the quiescent state of hematopoietic stem/progenitor cells and alters the pattern of hematopoietic regeneration after myelosuppression. Blood. 2011 Jan 13; 117(2):429-39. 
103. Broudy VC, Kaushansky K. Thrombopoietin, the c-mpl ligand, is a major regulator of platelet production. J Leukoc Biol. 1995 May;57(5):719-25.Review.

104. Debili N, Wendling F, Cosman D, Titeux M, Florindo C, Dusanter-Fourt I, Schooley K, Methia N, Charon M, Nador R, et al. The Mpl receptor is expressed in the megakaryocytic lineage from late progenitors to platelets. Blood. 1995 Jan $15 ; 85(2): 391-401$.

105. Chou FS, Mulloy JC. The thrombopoietin/MPL pathway in hematopoiesis and leukemogenesis. J Cell Biochem. 2011 Jun; 112(6):1491-8.Review.

106. Yoshihara H, Arai F, Hosokawa K, Hagiwara T, Takubo K, Nakamura Y, Gomei Y,Iwasaki H, Matsuoka S, Miyamoto K, Miyazaki H, Takahashi T, Suda T.Thrombopoietin/MPL signaling regulates hematopoietic stem cell quiescence and interaction with the osteoblastic niche. Cell Stem Cell. 2007 Dec 13; 1(6):68597.

107. Ayaz F, Osborne BA. Non-canonical notch signaling in cancer and immunity. Front Oncol. 2014 Dec 4; 4:345 e Collection 2014.Review.

108. Doan PL, Himburg HA, Helms K, Russell JL, Fixsen E, Quarmyne M, Harris JR,Deoliviera D, Sullivan JM, Chao NJ, Kirsch DG, Chute JP. Epidermal growth factor regulates hematopoietic regeneration after radiation injury. Nat Med. 2013Mar; 19(3):295-304. doi: 10.1038/nm.3070

109. Bigas, A, \& Espinosa, L. Hematopoietic stem cells: to be or Notch to be. Blood 119, 3226-3235 (2012).

110. Maillard I, Koch U, Dumortier A, Shestova O, Xu L, Sai H, Pross SE, Aster JC, Bhandoola A, Radtke F, Pear WS. Canonical notch signaling is dispensable for the maintenance of adult hematopoietic stem cells. Cell Stem Cell. 2008 Apr 10;2(4):356-66.

111. Radtke F, Wilson A, Mancini SJ, MacDonald HR. Notch regulation of lymphocyte development and function. Nat Immunol. 2004 Mar;5(3):247-53. Review.

112. Milner LA, Kopan R, Martin DI, Bernstein ID. A human homologue of the Drosophila developmental gene, Notch, is expressed in CD34+ hematopoietic precursors. Blood. 1994 Apr 15;83(8):2057-62. 
113. Karanu FN, Murdoch B, Gallacher L, Wu DM, Koremoto M, Sakano S, Bhatia M. The notch ligand jagged-1 represents a novel growth factor of human hematopoietic stem cells. J Exp Med. 2000 Nov 6;192(9):1365-72.

114. Suzuki A, Raya A, Kawakami Y, Morita M, Matsui T, Nakashima K, Gage FH, Rodríguez-Esteban C, Izpisúa Belmonte JC. Nanog binds to Smad1 and blocks bone morphogenetic protein-induced differentiation of embryonic stem cells. Proc Natl Acad Sci U S A. 2006 Jul 5;103(27):10294-9.

115. Kunisato A, Chiba S, Nakagami-Yamaguchi E, Kumano K, Saito T, Masuda S,Yamaguchi T, Osawa M, Kageyama R, Nakauchi H, Nishikawa M, Hirai H. HES-1 preserves purified hematopoietic stem cells ex vivo and accumulates side population cells in vivo. Blood. 2003 Mar 1;101(5):1777-83.

116. Stier S, Cheng T, Dombkowski D, Carlesso N, Scadden DT. Notch1 activation increases hematopoietic stem cell self-renewal in vivo and favors lymphoid over myeloid lineage outcome. Blood. 2002 Apr 1;99(7):2369-78.

117. Varnum-Finney B, Halasz LM, Sun M, Gridley T, Radtke F, Bernstein ID. Notch2 governs the rate of generation of mouse long- and short-term repopulating stem cells. J Clin Invest. 2011 Mar; 121(3):1207-16.

118. Duncan AW, Rattis FM, DiMascio LN, Congdon KL, Pazianos G, Zhao C, Yoon K,Cook JM, Willert K, Gaiano N, Reya T. Integration of Notch and Wnt signaling in hematopoietic stem cell maintenance. Nat Immunol. 2005 Mar;6(3):314-22.

119. Staal FJ, Clevers HC. WNT signalling and haematopoiesis: a Wnt-Wnt situation. Nat Rev Immunol. 2005 Jan; 5(1):21-30.

120. Staal FJ, Luis TC, Tiemessen MM. Wnt signalling in the immune system: WNT is spreading its wings. Nat Rev Immunol. 2008 Aug; 8(8):581-93.

121. Wilson A, Trumpp A. Bone-marrow haematopoietic-stem-cell niches. Nat RevImmunol. 2006 Feb; 6(2):93-106. Review.

122. Alakel N, Jing D, Muller K, Bornhauser M, Ehninger G, Ordemann R. Direct contact with mesenchymal stromal cells affects migratory behavior and gene expression profile of CD133+ hematopoietic stem cells during ex vivo expansion.Exp Hematol. 2009 Apr; 37(4):504-13. 
123. Deus GC, Normanton M, Hamerschlak N, Kondo AT, Ribeiro AA, Goldberg AC, Marti LC. Isolation and characterization of mesenchymal stem cells obtained from reusable and disposable bone marrow collection filters. Einstein (Sao Paulo).2012 Jul-Sep;10(3):296-301.

124. Oh IH, Lau A, Eaves CJ. During ontogeny primitive (CD34(+)CD38(-)) hematopoietic cells show altered expression of a subset of genes associated with early cytokine and differentiation responses of their adult counterparts. Blood. 2000 Dec 15;96(13):4160-8.

125. Broxmeyer HE, Douglas GW, Hangoc G, Cooper S, Bard J, English D, Arny M,Thomas L, Boyse EA. Human umbilical cord blood as a potential source of transplantable hematopoietic stem/progenitor cells. Proc Natl Acad Sci U S A. 1989;86(10):3828-32.

126. Gluckman E, Broxmeyer HA, Auerbach AD, Friedman HS, Douglas GW, Devergie A,Esperou H, Thierry D, Socie G, Lehn P, et al. Hematopoietic reconstitution in apatient with Fanconi's anemia by means of umbilical-cord blood from an HLA-identical sibling. N Engl J Med. 1989 Oct 26; 321(17):1174-8.

127. Jing D, Fonseca AV, Alakel N, Fierro FA, Muller K, Bornhauser M, Ehninger G,Corbeil D, Ordemann R. Hematopoietic stem cells in co-culture with mesenchymal stromal cells--modeling the niche compartments in vitro. Haematologica. 2010 Apr; 95(4):542-50.

128. Ara T, Itoi M, Kawabata K, Egawa T, Tokoyoda K, Sugiyama T, Fujii N, Amagai T,Nagasawa T. A role of CXC chemokine ligand 12/stromal cell-derived factor-1/pre-B cell growth stimulating factor and its receptor CXCR4 in fetal and adult T celldevelopment in vivo. J Immunol. 2003 May 1;170(9):4649-55.

129. Tzeng YS, Li H, Kang YL, Chen WC, Cheng WC, Lai DM. Loss of Cxc112/Sdf1 in adult mice decreases the quiescent state of hematopoietic stem/progenitor cells and alters the pattern of hematopoietic regeneration after myelosuppression.Blood. 2011 Jan 13;117(2):429-39.

130. Nie Y, Han YC, Zou YR. CXCR4 is required for the quiescence of primitive hematopoietic cells. J Exp Med. 2008 Apr 14; 205(4):777-83.

131. Ghosh MC, Collins GD, Vandanmagsar B, Patel K, Brill M, Carter A, Lustig A,Becker KG, Wood WW 3rd, Emeche CD, French AD, O'Connell MP, Xu M, Weeraratna AT, Taub DD. Activation of Wnt5A signaling is required for CXC 
chemokine ligand 12-mediated T-cell migration. Blood. 2009 Aug 13;114(7):1366-73.

132. Baron R, Kneissel M. WNT signaling in bone homeostasis and disease: from human mutations to treatments. Nat Med. 2013 Feb;19(2):179-92. doi: 10.1038/nm.3074. Epub 2013 Feb 6.

133. Zhang Y, Chai C, Jiang XS, Teoh SH, Leong KW. Co-culture of umbilical cord blood CD34+ cells with human mesenchymal stem cells. Tissue Eng. 2006 Aug;12(8):2161-70. 
